\title{
Heartfelt Love: Singing Maiden Characters in Romantic Vocal Music, 1800-1850
}

\author{
Haiman Liu
}

\author{
An exegesis \\ submitted to the Victoria University of Wellington \\ in partial fulfilment of the \\ requirements for the degree of \\ Master of Music
}

Victoria University of Wellington 2020 


\begin{abstract}
The images of maidens in Italian opera and German lieder from the period 1800-1850 are vivid. In the plots of the operas and the scenes and stories of the lieder almost invariably these characters focus enthusiastically on heartfelt love. This exegesis explores the relationship between the expression of love by unmarried women in selected lieder and opera of the first half of the nineteenth century and performance of these works by the young soprano in the twenty-first century. In the period when these songs and operas were written, performers of lieder would often have been of a similar age to the maiden characters portrayed in the songs, and in the case of Italian opera at the time, the singers who created such roles were usually in their twenties or early thirties. As a young soprano myself, in my study I consider some questions which are relevant for twenty-first century female singers who choose to perform these nineteenth-century portrayals of virgin characters. The figures in the works I have selected to study display a wide variety of personalities, moods and emotions, from the tenacious wild rose in Schubert's 'Heidenröslein', to his passionate Gretchen and the melancholic Amina in Bellini's La Sonnambula. I consider how the soprano may express the different emotions involved and approach performing young maiden characters such as these, whose experiences of life and status in society may be substantially removed from twenty-first century experiences.
\end{abstract}

In order to address these questions, I examine the selected song and aria texts in terms of the relationship between the content of the stories and the characters, as well as analyzing the vocal skills that can be used and vocal effects that may be applied when shaping these roles according to the music as written. In addition, I combine the background to the story and the plot with the musical markings in selected phrases to explore the emotional variety of the characters so as to interpret the deeper significance in the compositions. Through learning and performing these particular 
pieces I have explored the vocal techniques which are required in singing them from a practical perspective and this enables me to contribute insights I have gained to the general understanding of the skills required for this particular area of the repertoire. Having chosen repertoire for this study which combines Italian opera arias and lieder, and I also consider how the differences I have found in the vocal works may reflect their respective genres and distinguish the skills required for each. Through writing about my own research into the performance of these works, I provide new insights and ideas about these maiden characters which may be applicable to any young sopranos who sing repertoire from this period, and useful for their own vocal performances. 


\section{Table of Contents}

$\begin{array}{lr}\text { Abstract } & 2\end{array}$

$\begin{array}{lr}\text { List of Figures } & 5\end{array}$

$\begin{array}{lr}\text { Acknowledgements } & 6\end{array}$

$\begin{array}{lr}\text { Introduction } & 7\end{array}$

Vocal Music in the First Half of the Romantic Period 9

$\begin{array}{ll}\text { Historical Background of Opera and Lieder } & 11\end{array}$

$\begin{array}{ll}\text { Exegesis Overview, Methodology and Rationale } & 13\end{array}$

Chapter One - First Love: Morgenschön - so young and beautiful 19

'Heidenröslein' by Franz Schubert 19

Frauenliebe und -leben, Robert Schumann Op. 42 No. $1-5$

Summary - Singing the Maiden's Experience of First Love 39

Chapter Two - Sad Love: I miei sospiri - where shall I send my yearning cries? 41

'Die junge Nonne' by Franz Schubert 41

'Eccomi in lieta vesta...Oh! quante volte' (from Vincenzo Bellini’s I Capuleti e i Montecchi) 48

'Ah, non credea mirarti... Ah! non giunge' (from Vincenzo Bellini’s La Sonnambula) 58

Summary - The musical shaping of the maiden's sighs 66

Chapter Three - Passionate Love: Lento foco - the burning heart 68

$\begin{array}{lc}\text { 'Gretchen am Spinnrade’ by Franz Schubert } & 68\end{array}$

'Quel guardo il cavaliere... So anch'io la virtu magica' (from Gaetano Donizetti's Don

Pasquale) 74

'Ah! tardai troppo... O luce di quest'anima' (from Gaetano Donizetti's Linda di Chamounix) 84

Summary - the fiery energy of the maiden's passionate love 92

Discussion: Lieder and Aria Styles and Singing Skills $\quad 94$

$\begin{array}{lr}\text { Conclusion } & 98\end{array}$

$\begin{array}{lr}\text { Bibliography } & 105\end{array}$ 


\section{List of Figures}

\section{Chapter One - First Love: Morgenschön - so young and beautiful}

Figure 1. Fragment of 'Heidenröslein' (Bars 27-32) 23

Figure 2. Fragment of 'Heidenröslein' (Bars 11-15) 25

Figure 3. Fragment of 'Seit ich ihn gesehen' (Bars 1 to 11) 29

Figure 4. Fragment of 'Er, der Herrlichste von allen' (Bars 1 to 9) 29

Figure 5. Fragment of 'Helft mir, ihr Schwestern' (Bars 1 to 10) 30

Figure 6. Fragment of 'Du Ring an meinem Finger' (Bars 1 to 3) 30

Figure 7. Fragment of 'Er, der Herrlichste von allen' (Bars 15 to 23) 31

Figure 8. Fragment of 'Helft mir, ihr Schwestern' (Bars 46 to 52) 32

Figure 9. Fragment of 'Helft mir, ihr Schwestern' (Bars 26 to 35) 32

Figure 10. Fragment of 'Ich kann's nicht fassen, nicht glauben' (Bars 9 to 31) 34

Figure 11. Fragment of 'Ich kann's nicht fassen, nicht glauben' (Bars 43 to 64) 35

Figure 12. Fragment of 'Helft mir, ihr Schwestern' (Bars 41 to 45) 37

Chapter Two - Sad Love: I miei sospiri - where shall I send my yearning cries?

Figure 1. Opening section of 'Die junge Nonne' (Bars 1-12) 43

Figure 2. Ending section of 'Die junge Nonne' (Bars 75-83) 45

Figure 3. Fragment of 'Oh! quante volte' (Bars1-4) 50

Figure 4. Fragment of 'Oh! quante volte' (Bars 5-9) 51

Figure 5. Fragment of 'Oh! quante volte' (Bars 24-31) 51

Figure 6. Fragment of 'Oh! quante volte' (Bars 52-56) 52

Figure 7. Fragment of 'Oh! quante volte' (Bars 74-80) 53

Figure 8. Fragment of 'Oh! quante volte' (Bars 101-105) 54

Figure 9. Fragment of 'Ah! Non credea mirarti' (Bars 1-9) 60

Figure 10. Fragment of 'Ah, non giunge' (Bars 69-74) 61

Chapter Three - Passionate Love: Lento foco - the burning heart

Figure 1. Fragment of 'Gretchen am Spinnrade' (Bars 1-8) 69

Figure 2. Fragment of 'Gretchen am Spinnrade' (Bars 65-71) 70

Figure 3. Fragment of 'Gretchen am Spinnrade' (Bars 104-111) 71

Figure 4. Fragment of 'Gretchen am Spinnrade' (Bars 112-120) 72

Figure 5. Fragment of 'So anch' io la virtù magica' (Bars 39-46) 78

Figure 6. Fragment of 'So anch'io la virtù magica' (Bars 109-121) 80

Figure 7. Fragment of 'So anch'io la virtù magica' (Bars 168-181) 81

Figure 8. Fragment of 'So anch'io la virtù magica' (Bars 39-52) 83

Figure 9. Fragment of 'Ah! tardai troppo' (Bars 6-17) 86

Figure 10. Fragment of 'Ah! tardai troppo' (Bars 26-33) 87

Figure 11. Theme Note Pattern of 'O luce di quest'anima' (Bars 38-44) 89

Figure 12. Alternative way of performing ornaments of 'O luce di quest'anima'(Bars 40-43) 90

Figure 13. Fragment of 'O luce di quest'anima' (Bars 74-77) 91

Figure 14. Fragment of 'O luce di quest'anima' (Bars 107-112) 91 


\section{Acknowledgements}

Firstly, I would like to thank the examiners of my thesis. In addition, I would also like to thank Dr. Jenny Wollerman for her great guidance of my voice and thesis study, personal views in music and for successfully leading me to find a comfortable singing state. I am very grateful to my second supervisor, Inge van Rij, for her valuable comments about gender-related aspects on my exegesis as well. Also, many thanks also to my vocal teacher Wade Kernot and my vocal coach David Barnard for giving me so much help with my singing. I am so happy to have met the professional teachers and excellent colleagues who have contributed to my education at the New Zealand School of Music. It has given me a deep understanding and passionate yearning for music. Finally, I want to thank my husband and family for all their love and continued support. 


\section{Introduction}

When I first learnt to sing western classical vocal music of the first half of the nineteenth century, I noticed that the melody of the works involving young girls' feelings tended to be smooth and beautiful, and that most of these songs and arias were of moderate difficulty, which made them very suitable for the foundation and practice of singing. My voice teacher at that time often chose this kind of work for me as part of my singing training. In the learning process, what interested me in particular was how vivid the images of maidens were in the works written during this period and the way that most of them were young women who were enthusiastic for love. These girls are similar in age to most young sopranos which makes it easy for such singers to relate to the characters, but it also seems that the way the girls intensely relate to a desire for love represents a particular type of engagement with this emotion in these works. I call this 'heartfelt love', and the nature of its appearance in vocal works from the early romantic period is the focus of my thesis. I explore in this exegesis the ways in which 'heartfelt love' is expressed by young female characters within the music of early romantic lieder and opera, and how we can approach the performance of these nineteenth-century depictions of maiden characters in ways that emphasise and make sense of this loving sentiment.

In her essay 'Opera and Gender Studies', Heather Hadlock discusses the concepts prevalent at the time these works were written where women were thought of as "children" in that they were generally believed to have not "matured" fully as men had. ${ }^{1}$ This belief contributed to the social structure of the time and it could be argued that male composers used women as a weak symbol and made them representative of all women in the social order, which had been established by men to their own advantage. Nevertheless, the vivid nature of the characterisation of young women in

\footnotetext{
${ }^{1}$ Heather Hadlock, "Opera and Gender Studies," Chapter, In The Cambridge Companion to Opera Studies, edited by Nicholas Till, Cambridge Companions to Music (Cambridge: Cambridge University Press, 2012), $264-266$. 
these works still has potency today and I believe it deserves further attention. All of my chosen works for my recital were composed by male composers, so my interest in the theme of this young woman's love is how these male composers express the feelings of the women musically at the time, and in analyzing that music from the point of view of its composition and performance, in order to provide more musical understanding for other performers who are young sopranos, as well as for music lovers, and vocal teachers. Through learning and performing these particular pieces I explore the vocal techniques which are required in singing them from a practical perspective and am able to contribute the insights I have gained through this process to the general understanding of this particular area of the repertoire.

The young women in the works that I have chosen to focus on are chasing all kinds of love. Some of them fight against fate for love, others express admiration for their lover, and some suffer pains for their loved ones. Whether some of the composers might be trying to reflect general cultural expectations to sell more songs to young women by representing the characteristics the composer assumes those women would like to emulate or, as some have suggested, may be unconsciously or consciously expressing their own feelings about love through these characters, is outside of the scope of this study. ${ }^{2}$ Rather, I hope to analyze how these diverse and complex characters are represented musically, and explore the vocal works of maiden's love from the point of view of their composition and performance.

I will begin with a focused summary of relevant aspects of lieder and opera, including the relevant historical background and a timeline of the development of opera and lieder. Then I will discuss the innovation in various musical forms and the target audience. Finally, I will provide background information on the women these roles

\footnotetext{
${ }^{2}$ Victoria Hart, "Equals in love:"Frauenliebe und Leben" reconsidered," PhD diss., University of California, Santa Barbara, 2004, 6-7.
} 
were originally written for, including their ages, the personalities of the characters, and contexts for identification between role and singer.

\section{Vocal Music in the First Half of the Romantic Period}

In the birthplace of romantic music - nineteenth-century Europe - various revolutions emerged: social, political, industrial, technological, cultural, ideological and so on. After each revolution, the old basic ideas were cleared, and people's ideas about nature, society, spirit and material changed.

Romanticism grew out of late 18th-century 'sensibility', and both emphasised emotional expression, with increasing emphasis on subjectivity. ${ }^{3}$ At the same time, though, the various revolutions created a larger public audience (and consumers) of this music, so composers were also writing music that expressed middle-class ideals of gender - and faithful love was important in a patriarchal society that depended on women remaining true to their husbands and raising their children.

Under the trend of European romanticism, humanistic thought was becoming more and more free, however. Composers in the first half of the nineteenth century also emphasised their personal subjective feelings in the creation of female characters. Their works carried the colour of autobiography. For example, Schumann's Frauenliebe und -leben probably reflected his intimate affection for his wife Clara. ${ }^{4}$ In addition, in the description of love for unmarried female characters, composers created some female characters who fight against feudal forces for love. For example, Giulietta in Bellini's opera I Capuleti e i Montecchi, the wild rose in Schubert's lieder 'Heidenröslein' and so on. I propose that these works also reflect the possibility that

\footnotetext{
${ }^{3}$ Sensibility refers to the resistance of European bourgeoisie to the ruthless rationalism and rigid classicism of the ruling class in the late eighteenth century. They advocated expressing inner feelings, emphasizing individuality and personal spiritual life.

4 Victoria Hart, "Equals in love:"Frauenliebe und Leben" reconsidered," 7. 
the composers may have discovered the rise of the female consciousness of the society at that time, and that these themes point towards the feminist movement of the distant future.

One of the most important features of nineteenth-century vocal music was the new relationship between text and music. Composers began to emphasise the combination of music and poetry. Therefore, in the romantic period, lieder, a music form that closely combined German poetry and music, had appeared. In this exegesis, I study the unmarried female characters created by Schubert and Schumann, all of which are distinctive images created by the complementarity of literature and music. Also, composers began to obtain themes from dramatic literature or placing their stories in pastoral settings that involved the daily life of both peasants and gentry. For example, Bellini's opera I Capuleti ed $i$ Montecchi is based on the famous story Romeo and Juliet by Shakespeare. The opera La Sonnambula created by Bellini combined reference to the phenomenon of sleepwalking, which was drawing a great deal of attention in nineteenth-century Europe with a country setting.

Another important tool in expressing romanticism was harmony. The expansion and free use of dissonant harmonics, seventh and ninth chords, semitones and transpositions often appeared in romantic music, which enhanced the colour of harmony. Composers used rich musical theories when composing, which made the character and emotional creation of unmarried female characters more variable and delicate.

In the following chapters, I analyze the varieties in the images of these characters, especially their longing for love, missing their beloved, and inner changes to do with sadness and joy, in order to find out the vocal skills used in the character's emotional 
changes and analyze the singing difficulties. In addition, I study the related problems encountered by female singers in shaping the character in performance.

\section{Historical Background of Opera and Lieder}

\section{Opera}

The development of opera was directly influenced by the trend of romanticism, which emphasizes the freedom of human nature and the release of personal emotions. In nineteenth-century Italian operas, the choice of script also shifted from fabricated mysticism to realism, and there were a lot of plots that reflected 'real life' of contemporary people appearing on the opera stage. Therefore, a large number of young female characters of ordinary people appeared in the opera plots. For example, the village girl Linda, the country girl Amina and so on. In music creation, although the composers still paid great attention to the singer's singing skills, they paid more attention to the combination of these with the character's personality. Therefore, in the following chapters, I consider how singers can use vocal skills to express young girls' personalities and emotional changes in such works.

\section{Lieder}

Lieder is one of the most distinctive themes of romantic music, and this word is used only for German language songs. Stylistically the musical melody of lieder shows the harmony and unity of the rhythm of poetry and music in the genre. Composers of lieder regarded literature as a very important element for its creation. In addition, piano accompaniment was an indispensable part of lieder. Both the singer and the accompanist need to constantly render the mood of the melody and the emotions of the characters as well as the images from the poem. In my research, I explore in particular the way that Schumann used piano accompaniment as an emotional carrier to directly express the inner emotions of female characters. 
In the first half of the nineteenth century, the urbanization process brought about by the population explosion accelerated, the popularity of education and the development of the publishing industry promoted a significant improvement in the cultural literacy of the middle class. ${ }^{5}$ As a result, the middle class with leisure time and consumer desire began to pursue lieder music, which gradually formed a musical genre. Music publishers distributed more copies of lieder at a faster speed and at a lower price, making it more economical for the middle class to indulge in it. ${ }^{6}$ The promulgation of the 'Napoleonic Code' resulted in the deprivation of women's rights and the implementation of rights in favor of their husband. ${ }^{7}$ This contributed to the social trend of female-led entertainment culture within the home, including music culture. From the music works of this period, we can see the middle-class aesthetic orientation of the nineteenth century: a relaxed, poetic and decorative performance style, whose purpose perhaps was to cater to the female-dominated market. It is not surprising therefore that during this period, there were many romantic songs that were dominated by female characters.

Since the nineteenth century, with the emergence of a large number of lieder and concert halls, the original opera singers have gradually acquired a dual identity and were expected to sing both opera and lieder. Although the singing styles are different, they are branches of the bel canto singing art. ${ }^{8}$ In addition, as mentioned earlier, the characters of the vocal works in the first half of the nineteenth century were rich and dramatic, which is suitable for in-depth study of the characters' emotional fluctuations. Therefore, in this study I consider a selection of vocal works that centre on unmarried women in both opera and lieder, and compare the commonalities and differences

\footnotetext{
5 Jürgen Kocka, "The middle classes in Europe," The European Way: European Societies in the 19th and 20th Centuries, Oxford, Berghahn (2004): 29.

${ }^{6}$ Tyler Michael-Anthony Reece, "Liebe und Leben: Exploring Gender Roles and Sexuality in Nineteenth-Century Lieder." PhD diss., UC Santa Barbara, 2019, 18.

7 Rosemary Lloyd, "The nineteenth century: shaping women," A History of Women's Writing in France (2000): 120 .

8 James Stark, Bel canto: a history of vocal pedagogy, University of Toronto Press, 1999, 6-7.
} 
between lieder and opera in portraying young girls, in order to bring new revelation to vocal learners in singing and voice teachers in the teaching of lieder and arias in the future.

\section{Exegesis Overview, Methodology and Rationale}

The main part of my thesis is divided into three chapters. According to the different feelings of love experience of the girl characters in the songs, I have grouped the songs with similar emotions into the same chapter. In this way therefore, I am able to consider the similarities between the unmarried female characters created by the composers through music under similar emotions. Also, I explore what are the different performing techniques that singers need to portray heroines with similar emotions.

\section{Research Chapter Introduction}

Chapter One - First Love: Morgenschön - so young and beautiful

The girls in the selected songs have met the boy for the first time. The works describe the tortuous process of these female characters' meeting (happy), contact (dramatic contradiction), and separation (sadness).

Research Works: 'Heidenröslein' (Franz Schubert D.257 Op.3 No.3), Frauenliebe und -leben (Robert Schumann Op. 42)

Chapter Two - Sad Love: I miei sospiri - where shall I send my yearning cries?

The female characters in this chapter are in a state of pain after being hurt by love.

Research Works: 'Die junge Nonne' (Schubert D.828), 'Eccomi in lieta vesta... Oh! quante volte' (from Vincenzo Bellini's I Capuleti e $i$ Montecchi), 'Ah, non credea mirarti... Ah! non giunge' (from Bellini's La Sonnambula) 
Chapter Three - Passionate Love: Lento foco - the burning heart

The virgin characters included here are those who are crazy for love, full of love for their loved ones, and full of passion for love.

Research Works: 'Gretchen am Spinnrade' (Schubert D.118 Op.2 No.31)', 'Quel guardo il cavaliere... So anch'io la virtu magica' (from Gaetano Donizetti's Don Pasquale), 'Ah! tardai troppo... O luce di quest'anima' (from Linda di Chamounix)

\section{Female Roles' Background Information}

The purpose of the following chart is to let readers know in advance the background information of the virgin characters in the repertoire studied, especially the overall character of these images, and I give some contexts for identification between role and singer as well. Because the following exegesis is divided into three chapters according to the different emotions of the songs, we can see from the chart that the character traits of these female figures in works with similar situations or emotions are in fact very different, and the actual age of the singer performing the opera role at its premiere was often older than the plot implies the maiden character to be. I will discuss these aspects further in my later chapters.

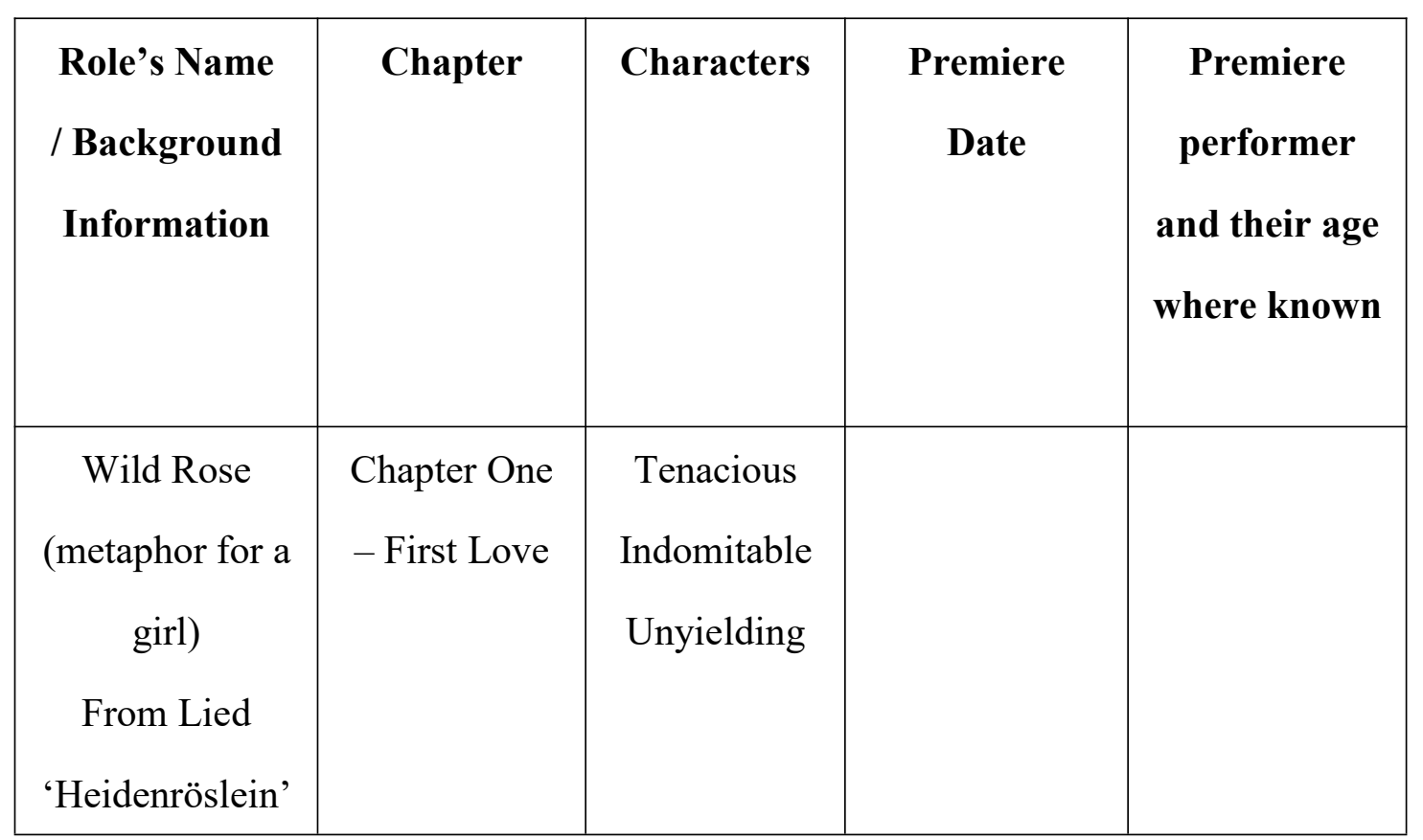




\begin{tabular}{|c|c|c|c|c|}
\hline $\begin{array}{c}\text { (Franz } \\
\text { Schubert) }\end{array}$ & & & & \\
\hline $\begin{array}{l}\text { Girl (may imply } \\
\qquad \text { Clara) } \\
\text { From song cycle } \\
\text { Frauenliebe und } \\
\text {-leben (Robert } \\
\text { Schumann) }\end{array}$ & & $\begin{array}{l}\text { Shy } \\
\text { Inferiority } \\
\text { Humility }\end{array}$ & & \\
\hline $\begin{array}{c}\text { Young Nun } \\
\text { From song 'Die } \\
\text { junge Nonne' } \\
\text { (Franz } \\
\text { Schubert) }\end{array}$ & $\begin{array}{l}\text { Chapter Two } \\
\text { - Sad Love }\end{array}$ & $\begin{array}{c}\text { Despair } \\
\text { Struggling } \\
\text { Peace }\end{array}$ & $1825^{10}$ & \\
\hline $\begin{array}{c}\text { Giulietta } \\
\text { From opera I } \\
\text { Capuleti e } i \\
\text { Montecchi } \\
\text { (Vincenzo } \\
\text { Bellini) }\end{array}$ & & $\begin{array}{c}\text { Helpless } \\
\text { Firmness } \\
\text { Longing for } \\
\text { love freedom }\end{array}$ & $\begin{array}{c}11 \text { March } \\
1830^{11}\end{array}$ & $\begin{array}{c}\text { Maria Caterina } \\
\text { Rosalbina } \\
\text { Caradori-Allan } \\
\text { (thirty years } \\
\text { old) }\end{array}$ \\
\hline $\begin{array}{c}\text { Amina } \\
\text { From opera } L a \\
\text { Sonnambula } \\
\text { (Vincenzo } \\
\text { Bellini) }\end{array}$ & & $\begin{array}{c}\text { Pure } \\
\text { Kindness } \\
\text { Sorrowful } \\
\text { Joyful }\end{array}$ & $\begin{array}{c}6 \text { March } \\
1831^{12}\end{array}$ & $\begin{array}{l}\text { Giuditta Pasta } \\
\text { (Thirty-four } \\
\text { years old) }\end{array}$ \\
\hline
\end{tabular}

\footnotetext{
${ }^{9}$ Clara Schumann (1819-1896) was the wife of the famous German pianist and composer Robert Schumann. Clara was also one of the most important pianists in romantic period.

${ }_{10}$ Wilfrid Mellers, Celestial music?: some masterpieces of European religious music, Boydell \& Brewer, 2002, 126.

${ }^{11}$ Gustav Kobbé, and George Henry Hubert Lascelles Harewood, Kobbé's complete opera book, Random House of Canada Ltd, 1987, 393.

${ }^{12}$ Gustav Kobbé, and George Henry Hubert Lascelles Harewood, Kobbé's complete opera book, 396.
} 


\begin{tabular}{|c|c|c|c|c|}
\hline $\begin{array}{c}\text { Gretchen } \\
\text { From song } \\
\text { 'Gretchen am } \\
\text { Spinnrade' } \\
\text { (Franz } \\
\text { Schubert) }\end{array}$ & $\begin{array}{c}\text { Chapter Three } \\
\text { - Passionate } \\
\text { Love }\end{array}$ & $\begin{array}{l}\text { Crazy for } \\
\text { love } \\
\text { Excited }\end{array}$ & & \\
\hline $\begin{array}{c}\text { Norina } \\
\text { From opera Don } \\
\text { Pasquale } \\
\text { (Gaetano } \\
\text { Donizetti) }\end{array}$ & & $\begin{array}{c}\text { Clever } \\
\text { Playful } \\
\text { Charming }\end{array}$ & $\begin{array}{c}3 \text { January } \\
1843^{13}\end{array}$ & $\begin{array}{l}\text { Giulia Grisi } \\
\text { (Thirty-two } \\
\text { years old) }\end{array}$ \\
\hline $\begin{array}{c}\text { Linda } \\
\text { From opera } \\
\text { Linda di } \\
\text { Chamounix } \\
\text { (Gaetano } \\
\text { Donizetti) }\end{array}$ & & $\begin{array}{l}\text { Passionate } \\
\text { Cheerful } \\
\text { Imagine } \\
\text { things }\end{array}$ & 19 May $1842^{14}$ & $\begin{array}{c}\text { Eugenia } \\
\text { Tadolini } \\
\text { (Thirty-three } \\
\text { years old) }\end{array}$ \\
\hline
\end{tabular}

\section{Research Methodology}

In this exegesis, I explore the writing and singing characteristics in vocal works with the theme of heartfelt love during this period, and consider what young students may need to learn in order to complete these singing skills well. The literary characteristics and aesthetic features will also be considered, in order to accurately grasp the meaning of characters in the music and the connotation in literature. In addition, I analyze the differences between these lieder and arias and the new performing problems encountered by female singers in shaping their characters.

\footnotetext{
${ }^{13}$ Burton D Fisher, Donizetti's Don Pasquale (Opera Journeys Mini Guide Series)., 2006, 16.

14 "Linda di Chamounix Opera: Work details," Royal Opera House Collections

Online, http://www.rohcollections.org.uk/work.aspx?work=212\&row=23\&letter=L\&.
} 
Regarding the consciousness of unmarried female characters in love in the nineteenth-century works, I am approaching this from a twenty-first century perspective that is quite different to that of my characters. Moreover, in the twenty-first century, I also find that although feminist music criticism has led people to re-examine the role of women in the history of music, given the long history of male domination, a great many people still believe that women do not have the ability to make history. Therefore, in looking back to the nineteenth century, it is one of the motivations of my research to find out how these maiden characters influenced the history of compositional development and even the composer's later aesthetics.

My research is based from the perspective of qualitative research in order to understand the historical background of vocal music during the period of 1800-1850 and analyze the creative characteristics of songs as well as explore the performance techniques in singing practice. I base my exploration initially on existing scholarly writing.

I discuss selected fragments and show common vocal features within the selected groups of works to identify compositional features associated with the expression of the maiden's feelings. I explore the connections between the opera and lieder from these compositional aspects and singing techniques. I classify literary themes from which the texts are selected and analyze how piano accompaniment and vocals are combined through the rehearsal of the recital with my piano accompanist. Also, I try to find a variety of rhythm types used to express the rich feelings of maiden characters, and study how to convert heroine emotions through tonal interchanges. In addition to the research on compositional features, I study the singing and performance of characters. In order to put these techniques into practice, I study the relevant theories of Bel Canto including the control of breath, the unity of sound zone, the coherence 
and lyricism of voice, the clear speaking of words and physical movement performance as well as apply these findings to my practical singing. Combining bel canto theory with my singing experience when preparing for the recital, I analyze the singing skills that need to be used when singing these pieces, aiming to accurately grasp the singing characteristics of unmarried female characters. I also try to find common effective singing methods to maximize the expression and integration of the performance styles in opera and lieder. The practical investigation of such techniques inform my writing about these works, and I perform the results of my study in my recital.

\section{Rationale}

This exegesis aims to provide more musical understanding for other young soprano players as well as music lovers and vocal teachers. By studying and performing these specific music pieces, I explore the vocal skills needed for singing from a practical perspective, and contribute to the general understanding of this particular field of music. Moreover, from studying these vocal works, I have been able to gain a better understanding of how these virgin characters fit into the history of composition development in the nineteenth century and may even have influenced the composer's later aesthetics.

The whole thesis provides insights for young female singers who wish to play such roles. In addition, the thesis can also bring inspiration to vocal pedagogy, by providing valuable historical insights, musical information and a theoretical basis for voice teachers who are working on both opera arias and lieder, allowing them to apply these new ideas to their vocal teaching. 


\section{Chapter One - First Love: Morgenschön - so young and beautiful}

\section{'Heidenröslein' by Franz Schubert}

\section{Song and Text}

Firstly, I will examine the text of the poem by Johann Wolfgang von Goethe (1749-1832) poem as set by Schubert in this song. It seems in fact that Goethe adapted the lyrics to this poem in 1789 basing it on various sources of 'folksongs' including a collection by Paul von der Aelst dating from 1602. ${ }^{15}$ This published version was later composed into the lied by Schubert in 1815. At this time, the perfect fusion of poetry and music in a larger number of lieder also reflected the vigorous development of German literature and art in nineteenth century. ${ }^{16}$ It could be argued that Goethe's main subject in 'Heidenröslein' is not the boy, but a girl who has been described as a wild rose. And the textual focus of expression is the unfortunate encounter of this young girl, because although each stanza begins with the boy, it all ends with the exclamation 'wild roses': 'Röslein, Röslein, Röslein roth, Röslein auf der Heiden'. This sentence is repeated in the text three times, reflecting the the emphasis on the subject of the wild rose. The poet uses the wild rose to represent the image of a maiden, describing her story of tenacious and unyielding struggle with fate at the end of which she is still miserable. The following is the English translation:

Sah ein Knab' ein Röslein stehn, The boy saw the wild rose,

Röslein auf der Heiden, Rose on the hedgerow,

War so jung und morgenschön, It's so young and beautiful in the morning,

Lief er schnell es nah zu sehn, He hurried to look forward,

\footnotetext{
${ }_{15}$ Richard, "Goethe's Heidenröslein," Figures of Speech, Updated July 25,

2017, http://figures-of-speech.com/2017/06/r\%C3\%B6slein.htm.

${ }^{16}$ Lorraine Byrne Bodley, Schubert's Goethe Settings Burlington, VT: Ashgate, 2003, 114-115. 
Sah's mit vielen Freuden.

Röslein, Röslein, Röslein roth,

Röslein auf der Heiden.

Knabe sprach: ich breche dich,

Röslein auf der Heiden!

Röslein sprach: ich steche dich,

$\mathrm{Da} ß$ du ewig denkst an mich,

Und ich will's nicht leiden.

Röslein, Röslein, Röslein roth,

Röslein auf der Heiden.

Und der wilde Knabe brach

's Röslein auf der Heiden;

Röslein wehrte sich und stach,

Half ihr doch kein Weh und Ach,

Mußt' es eben leiden.

Röslein, Röslein, Röslein roth,

Röslein auf der Heiden
He looked at it with great delight.

The rose, the red rose,

On the hedgerow.

The boy said I want to pick you up,

Rose on the hedgerow!

The rose said I want to stab you,

So that you will often remember me,

And I won't be sorry about you.

The rose, the red rose,

On the hedgerow.

The boy finally came to pick it,

Rose on the hedgerow,

The rose defended itself and struck,

Suddenly giving him pain, Ah,

He will simply have to suffer.

The rose, the red rose,

On the hedgerow.

The original lyrics and English translation of 'Heidenröslein' by Haiman Liu.

It can be seen that the poem comprises just three short stanzas, each of which is a different scene. In these three scenes, the emotions of the wild rose as the subject are very dramatic. As the singer, or the narrator of the story, no matter whether I put myself into the first-person perspective or the third-person perspective, I need to show three different moods and feelings according to the different parts of this poem. 
As you can see in the first part, the perspective is descriptive. The boy discovers the rose, and is especially happy in his heart, so he rushes forward and looks at the rose. It can be understood that the poet is introducing the background of this story, while showing the character of wild rose as well. Through the above translation, we can learn that this wild rose described by Goethe is blooming in health, which shows that her vitality is tenacious. Therefore, the character of a young girl represented by a wild rose emerges. From the text, we can find that she is not only young and beautiful, but also wild, because this is the girl represented by wild roses. Thus, she is portrayed as a tenacious girl, which also showed that she might fight for her destiny. Because the sight of such a beautiful wild rose is rare, the exclamation at the end of the first part can be understood as his love and praise for such a personal wild rose.

In the second part, the dramatic conflicts arise. The author uses metaphorical means to describe the "dialogue" process between the boy and the rose. This process not only shows the innocence of the boy, but also shows that the rose cannot resist and is vulnerable to the boy who picks it. The boy wants to pick the wild rose and the rose fights back strongly. Because there are two images in this part-a boy and a girl who is metaphorized as a wild rose, we can find that two characters with completely different image styles will have the conversation in the lyrics to strengthen the dramatic conflict. And the last sentence repeated in this part's text can be understood as the perspective changed into a third person again, there is another exclamation of the character of wild rose shows the urgency of the situation when the boy wants to pick wild rose.

In the third part, the boy finally picks the rose as he wishes. Although he is stabbed, he still cannot hide his joy. In this way, the author puts forward the ending of the second dramatic conflict, which ends with the failure of wild rose's resistance. 
However, the rose stabs the boy as well, and the last repetitive phrase could be taken to be admiration for the rose which was so strong at defending herself.

When I analyze this text by Goethe, I have already assigned these two roles to gender and feminized the wild rose. In addition, it can be interpreted that Goethe's poem has multiple meanings. The wild rose symbolizes the young girl, and the rose stabs the boy represent that the girl rejects the boy's pursuit and defends herself. At the end, the boy picks wild rose but will probably endure the torment of love forever, because he wants to evoke the love returned by wild rose through his strong love, but she is so unyielding that it makes the boy's heart broken. The wild rose's tenaciousness and composure exemplify the character of a tenacious rebellious girl.

\section{Performance Skill}

According to this idea, this song is expressed as a short play. The narrator, the teenager and the wild rose are three distinct characters. Because the two main characters, the boy and the girl symbolised by the wild rose are relatively young, they embed the various emotions into three parts of the music, which makes the whole song come alive. The tempo of this lied is relatively fast and it is also marked by "lieblich" (lovely). The piano accompaniment uses a large number of left and right hand alternating chords, which can be interpreted as describing running, and gives the whole song a more lively mood. The corresponding rhythm patterns in the vocal part are also short and bouncy. ${ }^{17}$ This type of tempo and rhythm requires the singer to use a flexible and lightweight sound, and at the same time I need to know where to be legato and where to be less legato.

Female singers can substitute themselves into the role of wild rose, and they can use different vocal skills in combination with the three different sections of the text. The

\footnotetext{
${ }^{17}$ Maurice John Edwin Brown, and Eric Sams, The New Grove Schubert. WW Norton \& Company, 1983, 78.
} 
first part describes the boy's first love of the rose. It can be sung in accordance with the rhythm of music and does not need to add any extra expressive effects. It is not necessary to slow down but sing in a relaxed and joyful expression in order to convey the mood of the boy. The second part produces a metaphorical conversation between the boy and the rose. The boy is about to pick the rose, but the rose will hurt him with its thorn, which is obviously different from the beauty of the rose which was the only characteristic described in the first part. The singer could strengthen the tone of the boy's dialogue with the rose in the singing, especially the tone of the rose that represents the character of the young girl. When singers sing that the rose says she will stab the boy, the tone could be slightly low and rough. It is different from a light tone before, which showing the wild rose's anger. In bar 27, it should be gradually slower. And in terms of singing technique, the singer can put a weak voice on the high note- G5, to express the rose's desire to survive. In the last part, the wild rose is finally picked, and the boy is also stabbed. The mood of the singer here can represent the sadness in the loneliness of the boy or the rebellious anger representing the wild rose. I prefer to choose the first kind of interpretation, because it is more in line with the rhythm of returning to the original state of the first part. However, although the rose's resistance failed, she fights for her destiny. Therefore, when the singer sings at the end, the singer's expression can include admiration for the rose.

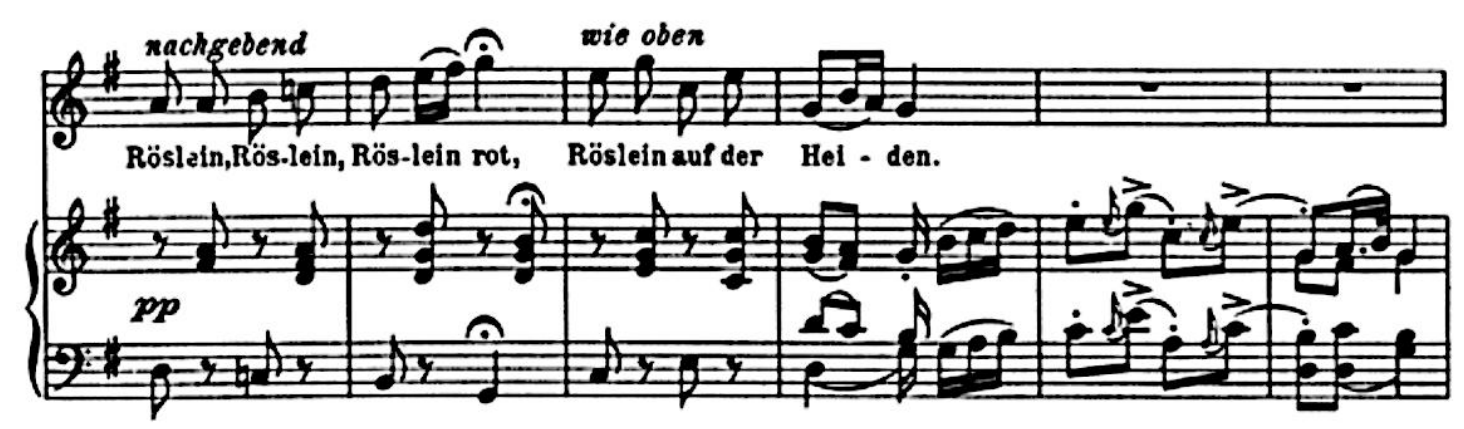

Figure 1. Fragment of 'Heidenröslein' (Bars 27-32) ${ }^{18}$

\footnotetext{
18 The figure is taken from

https://imslp.simssa.ca/files/imglnks/usimg/c/c1/IMSLP00890-Schubert_-_Heidenr\%C3\%B6slein_Op3-3.pdf. All the other figures for this song are from the same edition.
} 
In addition, although the melody of 'Heidenröslein' is sometimes cheerful, and sometimes the content of the lyrics makes us angry, overall it is a lively Lied, so female singer's emotional expression can be open and humorous. The way the singer embodies the characters in her performance can be exaggerated a little as well, and the facial expression can be relaxed and pleasant while still being slightly dramatic.

\section{Emotional Expression}

Starting from the lyrics, we can divide this poem into three stages: encounter (to produce love), contact (to create conflict), and disappointment (to break up sadly). These three parts clearly explain a story completely, the beginning, development, climax of the story, and the construction of a very rich dramatic effect. In order to start singing in three identical parts of music, performers need to understand the meaning of each part, build an overarching scene frame in our mind according to the content of the words, and then start to arrange our singing around this structure. This provides integrity, coherence and fluidity in the process of interpreting the connotation of the work in the singing.

As mentioned earlier, the phrase 'Röslein, Röslein, Röslein rot, Roslein auf der Heiden' is repeated three times during the song (see Figure 2 below). Each repetition uses exactly the same melody, but the meaning each time can be different. As the scale of the main melody continues to ascending progression with the mark of ritard, the emotional expression can be more abundant. The pause note in this phrase also gives the singer a great deal of freedom. Using different emotional expressions in these three repeats may also allow for the audience to connect more emotionally to the performance. At the very end, the song returns to its original tempo, as if everything has reverted to its original state, and like it never happened. 


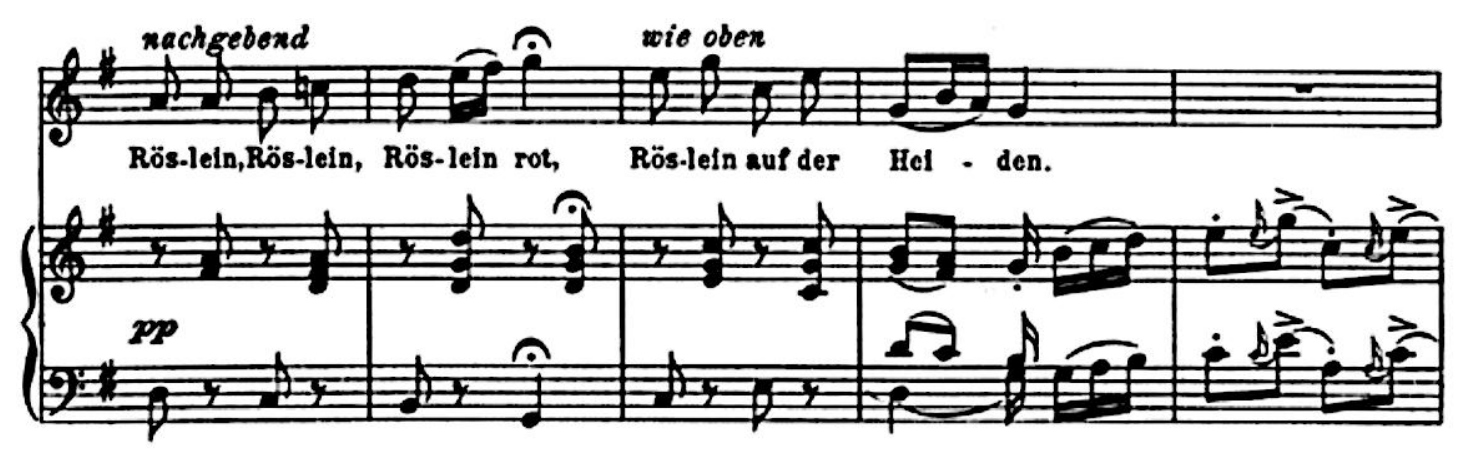

Figure 2. Fragment of 'Heidenröslein' (Bars 11-15)

\section{Wider Meanings}

The boy in 'Heidenröslein' picks the rose the first time he meets it, so his first love for wild rose is very overbearing. This could be interpreted as the author's reprimand for the brutal courtship of the cavalier era, and the complaint about the knight's disrespect for women's marital autonomy. ${ }^{19}$ Moreover, the song is unique in that it anthropomorphizes the wild rose, compares it to the character of a young girl. Although she looks like a maiden, it symbolizes a woman who dares to contend with fate, especially unfair marriage. However, this is contrary to the situation of most women in the nineteenth century. Whether in the aristocratic class or the middle class, in most instances, women could not choose their own marriage partners. Aristocratic women's marriages were based on property and family lineage, resulting in numerous family tragedies of loveless marriages. ${ }^{20}$ The women among the middle-class population were in a difficult situation under the oppression of patriarchy. In order to defend their authority and consolidate their property, fathers might try to force their daughters to marry particular husbands against the daughter's wishes. The tragedy of women in this situation is the inevitable result of the supremacy of patriarchy. This is also reflected in the story behind 'Oh! Quante volte' (from I Capuleti e i Montecchi) as discussed later. Finally, the wild rose stabs the boy although he has picked it. This means that she has also fought back, which can be seen as reflecting the nascent

\footnotetext{
19 Sidney Painter, French Chivalry: Chivalric Ideas and Practices in Mediaeval France, Cornell University Press, 1940, 110-111.

${ }^{20}$ Theodore Evergates, "Aristocratic Women in the County of Champagne." Aristocratic Women in Medieval France (1995): 74-75.
} 
desire of nineteenth-century European women towards fighting for political and economic rights. ${ }^{21}$ Although they could not yet overcome the shackles of patriarchy, it aroused female consciousness and set the banner for future feminist movements.

\section{Frauenliebe und -leben, Robert Schumann Op. 42 No. 1 - 5}

Robert Schumann based his Frauenliebe und -leben song cycle on the long poem of the same name by the German romantic poet Adelbert von Chamisso (1781-1838). Chamisso's original poetry collection has nine poems in all, but Schumann omits the last one. ${ }^{22}$ In the poems, Chamisso appeals to readers' strong emotional resonance through the vivid description and psychologically-based portrayal of the love process of a girl's life. Schumann provides a chronological narrative in this cycle. ${ }^{23}$ This narrative follows the girl's path from the first meeting of her beloved, falling in love with him, her surprise that he wants to marry her, to engagement, marriage, the birth of her first baby, and finally, widowhood. Schumann uses unpretentious melodies to express the profound connotation of poetry. He uses concise forms and simple musical language to depict the progression of women from joy to sorrow, and delicately expresses the changes in women's inner feelings.

Schumann's music can reflect the female character's psychological and personality changes. John Daverio and Eric Sams point out that Schumann is able to clearly show a balance between naive childishness and refinement, especially in melody. In terms of childishness, Schumann creates a pure and flawless virgin image. In terms of refinement, although the vocal lines he creates are beautiful, they can just match the

\footnotetext{
${ }^{21}$ Hilary Poriss, and Rachel Cowgill, The Arts of the Prima Donna in the Long Nineteenth Century, New York ;: Oxford University Press, 2011, 29-31.

${ }^{22}$ Megan Evangeline McCauley, A woman's timeless path of life and love: Voicing and the feminine persona in Robert Schumann's “Frauenliebe und Leben”, Opus 42, and David Eddleman's “Journey”, University of Kentucky, 2010, 3-4.

23 John Daverio, and Eric Sams, "Schumann, Robert," Grove Music Online. Oxford Music Online (2001), 26.
} 
accompaniment, and the interaction creates a delicate dialogue. ${ }^{24}$ This is very similar to the story's division into stages in the previous lied I discussed, 'Heidenröslein'. In the same way it describes the tortuous process of the meeting (happy), the contact (a dramatic contradiction), and separation (sadness) of the female and male. However, since this thesis studies the characters of unmarried girls, I will only focus on the analysis of the first five songs, to consider how the heroine's images develop before her marriage. Before this period her emotional changes are all positive, and do not reach the extent of dramatic conflict or grief, but in this work we can still find the girl's images shaping her various psychological responses to her first love.

The first five songs of this cycle are short and delicate. In the first song 'Seit ich ihn gesehen (Since I First Saw Him)' the innocent girl sees her lover for the first time, she is fascinated by his appearance, and she falls in love. The second song 'Er, der Herrlichste von allen (He is the Most Wonderful)' is the girl praising the man she loves and wondering if she matches him in other words whether she is 'good enough' for him. In the third song 'Ich kann's nicht fassen, nicht glauben (She Cannot Believe it)': as if in a dream, he actually chooses her. The fourth song 'Du Ring an meinem Finger (You Ring on My Finger)' describes how her dream has become a reality: the engagement ring has been put on her finger. The fifth song 'Helft mir, ihr Schwestern (Help Me, My Sisters)' is on her wedding day, and her friends are dressing her up to welcome the arrival of happiness.

\section{The Importance of the Piano Accompaniment}

In the early lieder form of the German narrative song at the end of the eighteenth century, the keyboard part changed from just a musical part which provided rhythmic and harmonic support for a melody to an accompaniment which, when combined together with the vocal part, serves to set off, explain and strengthen the meaning of

${ }^{24}$ John Daverio, and Eric Sams, "Schumann, Robert," 24-25. 
the poetry. ${ }^{25}$ As the heir to Schubert's art song style developments, Schumann makes the piano accompaniment a prominent feature of his own art songs. Schumann had a passionate attachment to Schubert's music, however, the piano and voice in Schumann's works have a psychologically different ideological connection. ${ }^{26}$ Schumann does not treat piano accompaniment as a kind of scene description like Schubert, but uses it as an emotional carrier to directly express the subject's inner emotions. $^{27}$

1) In Frauenliebe und -leben, the piano part plays an important role in deeply depicting the girl's inner world through the use of rich sound patterns to express the virgin's emotional changes. Taking Schumann's use of chords as an example, in the first song, the piano prelude is based on the melody of the first phrase of the vocal line of the song, using the 'bouncy' semi-staccato column chords with rests, in a calm rhythm to express both the girl's excitement and her sigh (see Figure 3). In the second song, the accompaniment uses the chord tremolo, which provides a portrait of the girl's passionate heartbeat (see Figure 4). In the fifth song, the piano accompaniment has arpeggio chords with dotted notes, which not only portray the lively scene of the wedding, but also the footsteps of the busy crowd (see Figure 5).

\footnotetext{
${ }_{25}$ Lotte Lehmann, Eighteen Song Cycles; Studies in Their Interpretation, New York: Praeger Publishers, 1972, 92.

26 John Daverio, and Eric Sams, "Schumann, Robert," 24.

27 Susan Youens, "Song Cycle," Grove Music Online, Oxford University Press, January 20, 2001, 6.
} 

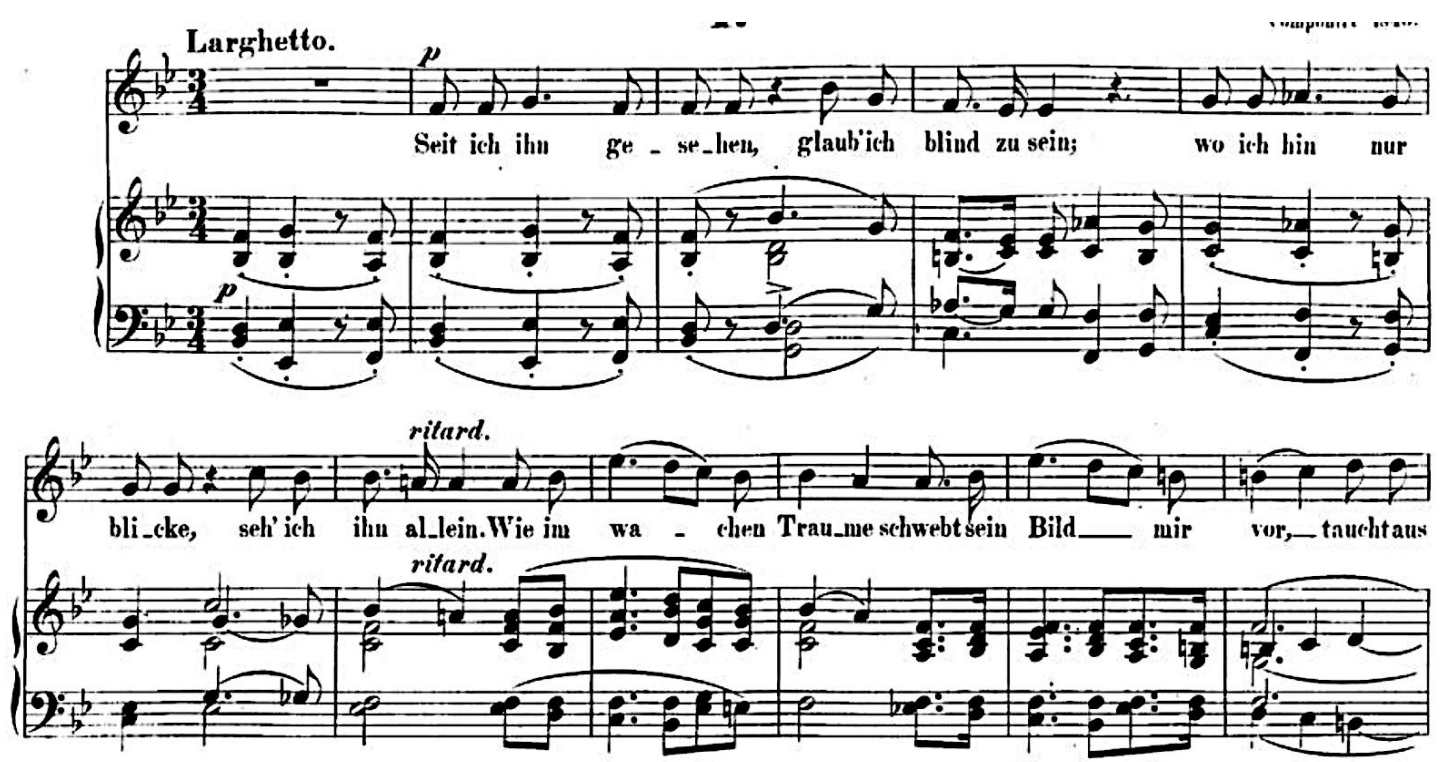

Figure 3. Fragment of 'Seit ich ihn gesehen' (Bars 1 to 11$)^{28}$

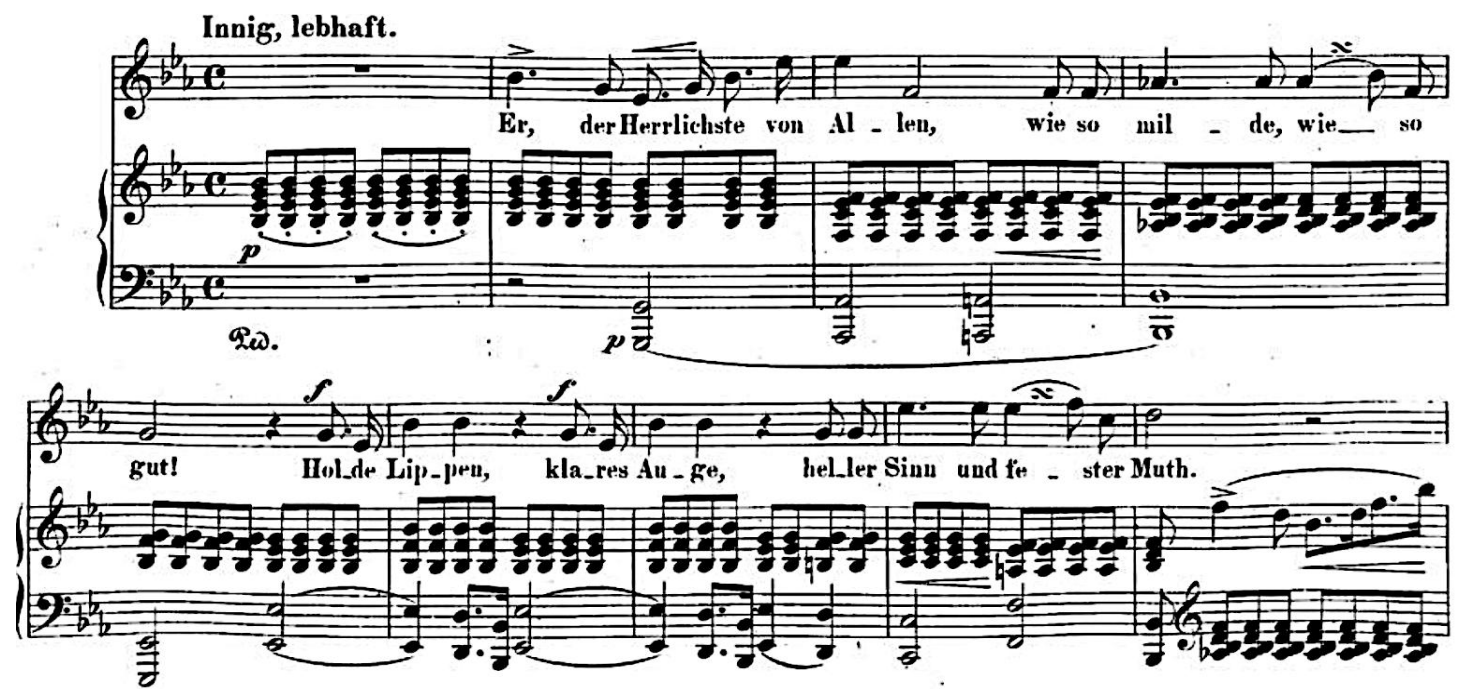

Figure 4. Fragment of 'Er, der Herrlichste von allen' (Bars 1 to 9)

28 The figure is taken from

https://imslp.simssa.ca/files/imglnks/usimg/a/a0/IMSLP51733-PMLP12743-RS129.pdf.

All the other figures for this song cycle are from the same edition. 

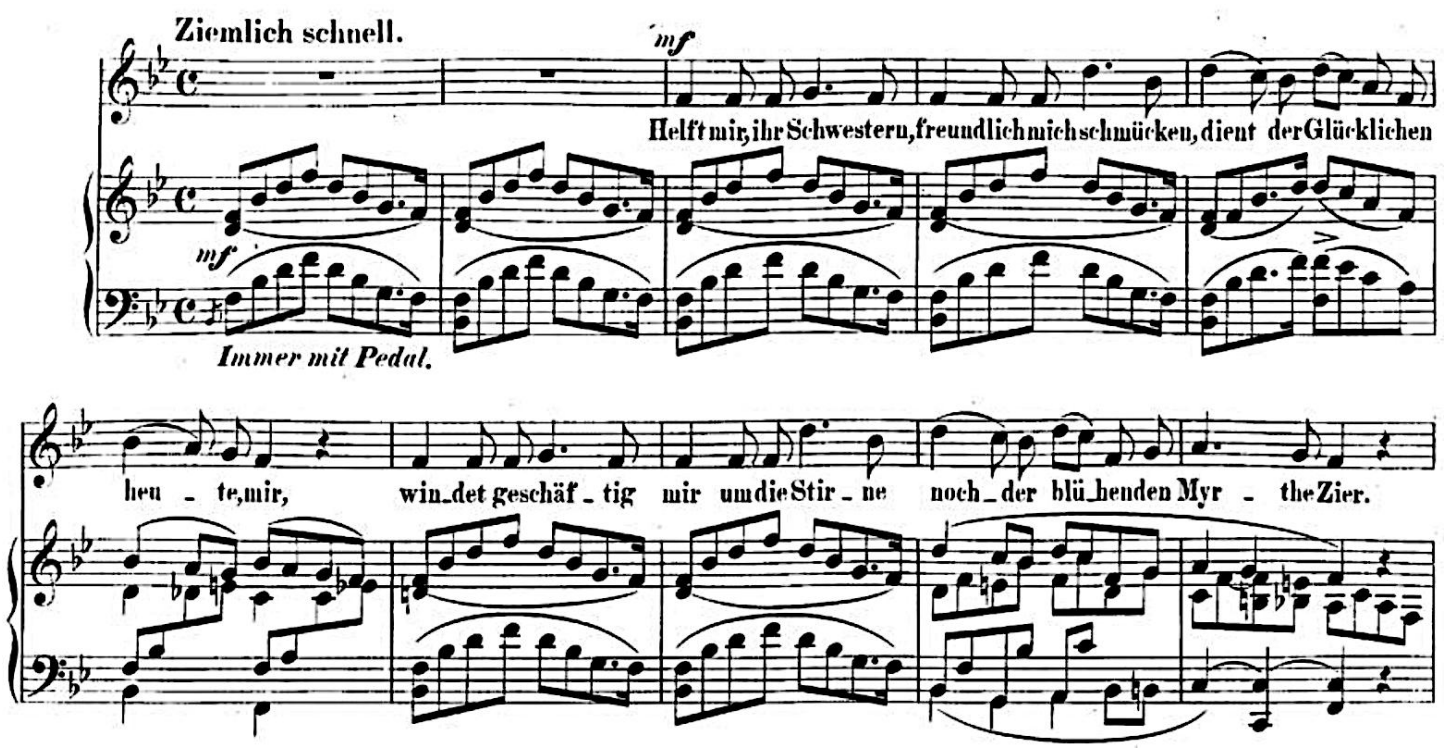

Figure 5. Fragment of 'Helft mir, ihr Schwestern' (Bars 1 to 10)

2) In other places the piano accompaniment is like a duet with voice, providing a complementary part to the voice. In the fourth song, the texture of broken chords is used, and the right hand part plays the same melody as the voice (see Figure 6). This gives a sense of integration. I find that this kind of situation also existed in Schubert's works, but only some bars have overlapping parts. However, in this song, Schumann almost overlaps the piano right-hand high part and vocal part for the whole song. In this way, both the accompaniment and singer can express the woman's indulgence in love with a nearly consistent breath.

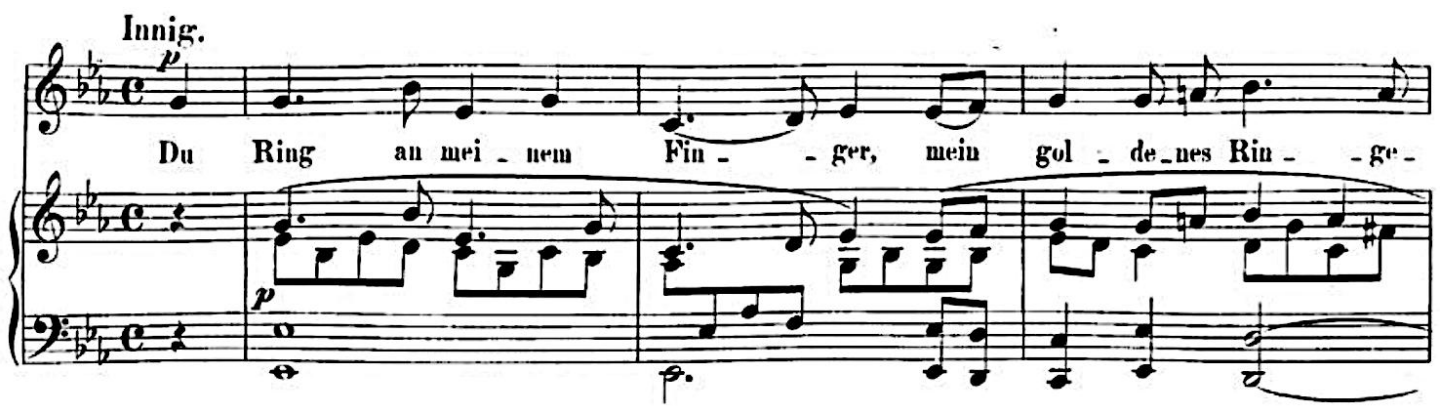

Figure 6. Fragment of 'Du Ring an meinem Finger' (Bars 1 to 3) 
3) In this cycle, the prelude to each song is often very simple, but the interlude and ending are delicately designed. ${ }^{29}$ For example, in the second song, the interlude between the first and second parts repeats the melody at the beginning of the vocal part. Daverio and Sams suggest that Schumann use retelling to reflect past memories. Both melody recurrence techniques emphasize the power of memory. ${ }^{30}$ However in this song, I believe that the piano line always shows the happy voice of the heroine when it traces widely spaced melodic lines (as in Figure 7).

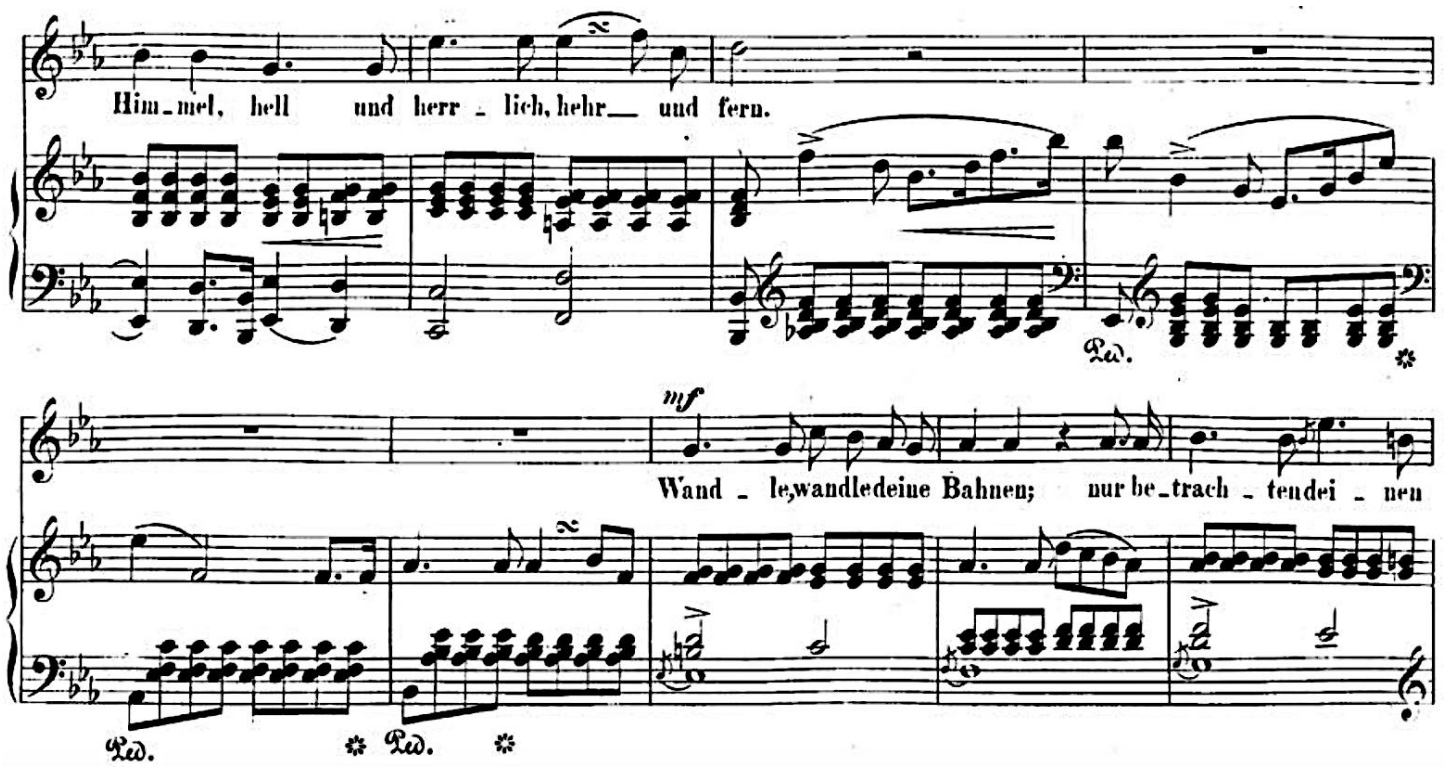

Figure 7. Fragment of 'Er, der Herrlichste von allen' (Bars 15 to 23)

In addition, the postlude played by the piano can accurately shape a series of musical characters, forming an inseparable part of the song's expression of meaning. For example, in the last six bars of the fifth song, the piano plays regular phrases like march, which represent the progress of the wedding (see Figure 8).

29 Richard Miller, Singing Schumann: An Interpretive Guide for Performers Oxford: Oxford University Press, 2005, 85-86.

30 John Daverio, and Eric Sams, "Schumann, Robert," 26. 


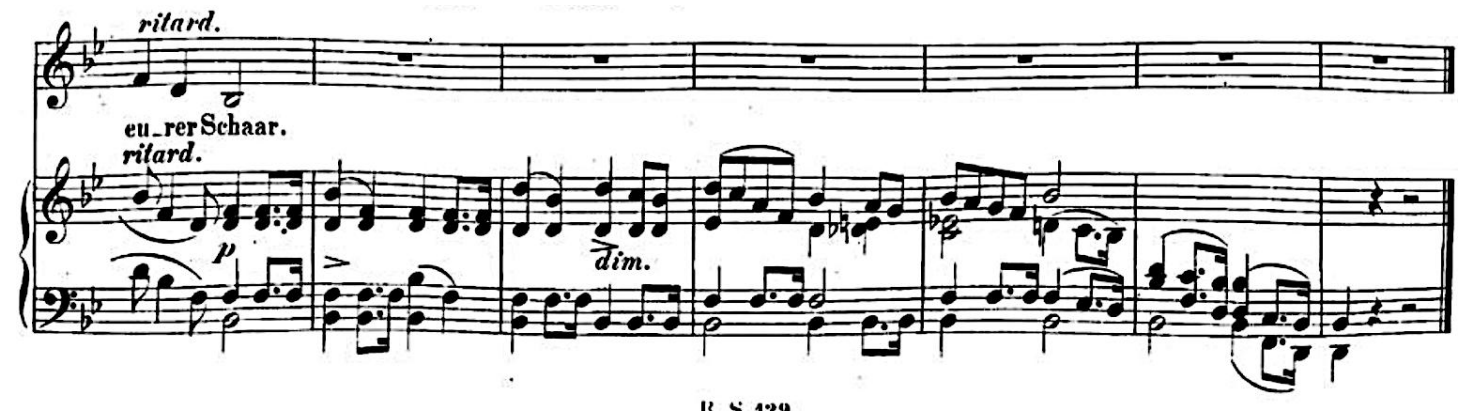

Figure 8. Fragment of 'Helft mir, ihr Schwestern' (Bars 46 to 52)

4) The change of tempo and dynamic in Schumann's piano accompaniment can also portray different emotions and moods. The piano part can express the excited and uneasy mood of the maiden through the change of tempo. In the fifth song, the initial tempo indicated is Moderato, but the tempo becomes faster from bar 25. The dynamic is also slightly strengthened, which reflects the girl's determination and excitement for love. Then from bar 33, the tempo slows down again, the dynamic is weakened and the song ends with comfort and quietness, to show that she is intoxicated with happiness (see Figure 9).
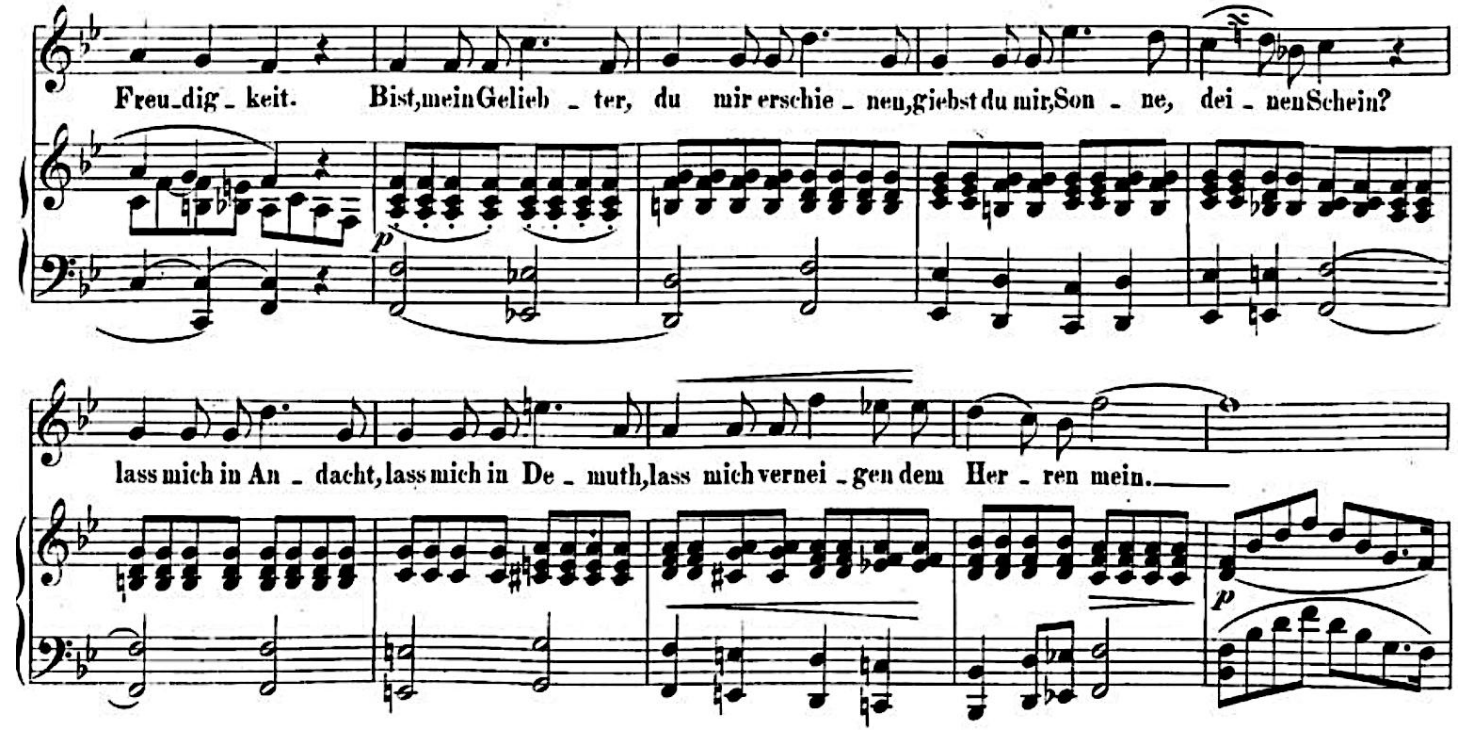

Figure 9. Fragment of 'Helft mir, ihr Schwestern' (Bars 26 to 35)

\section{Voice Character of Virgin}

In Frauenliebe und -leben, it is necessary to make use of variety and contrast on the basis of vocal tone to reflect the age span and the inner changes of the character. 
Singers can also vary their dynamic, tempo, lyricism and use other vocal artistic effects. In the following section, I analyze the aspects of vocal character relevant to this cycle from the following two points of views.

\section{1) Characteristics of Voice at Different Ages}

In the first five songs of the cycle, the heroine's age has a span, which is a process from the young girl stage to the pre-marriage stage. In order to better grasp the psychological and emotional changes of the character, it is necessary for the singer to express the voice characteristics of various ages, so that the character images can be more accurately shaped. I will explain in detail how to make the character perform more effectively at different ages by singing.

\section{i Young Girl}

The expression of the character's age changes mainly depends on changing tone colour, dynamic and resonance cavity. The voice characteristics of the girlish stage are soft, sweet, and clear in tone, and the change in dynamic is not very large. The high notes are mostly processed with gentle sounds.

The first three songs are the images of a young girl who is not yet ready to get married. From seeing a lover to being selected by the lover, this stage mainly reflects the subtlety and shyness of the girl. The singer's voice can be soft and sweet, and it does not need to be exaggerated when excited as well. In the first song, the volume of the sound needs to be controlled by the singer, and singers can maintain the smoothness of the breath and the consistency of the voice. The tone does not need to be too bright here, as if the girl is talking to herself and she is ashamed to tell people what she is thinking about. 
When we are singing 'Er, der Herrlichste von allen', the tone needs to be light, in order to expresses the girl's praise and blessing of the person she likes. The clear pronunciation of 's' in German can also help by making the solo part bright. The beginning of the song is marked with accent marks, and then we need good support and stabilisation to do a well controlled dynamic change (see Figure 4).

The third song's first part can highlight the girl's flattered mood. The voice should be decisive when entering on the strong beat. The singer needs full breath but not excessive. At bar 7, it can be processed to slow down to show her doubts about her dream. After that, the voice can become slightly softer and the volume needs to be controlled, because it is necessary to show that the girl does not understand why this man chooses her to love, and this also can express girl's sense of inferiority which is made clear by the poem's text. After entering the second part (see Figure 10), the tempo is slower than the first part, and the tone is more gentle and lyrical.

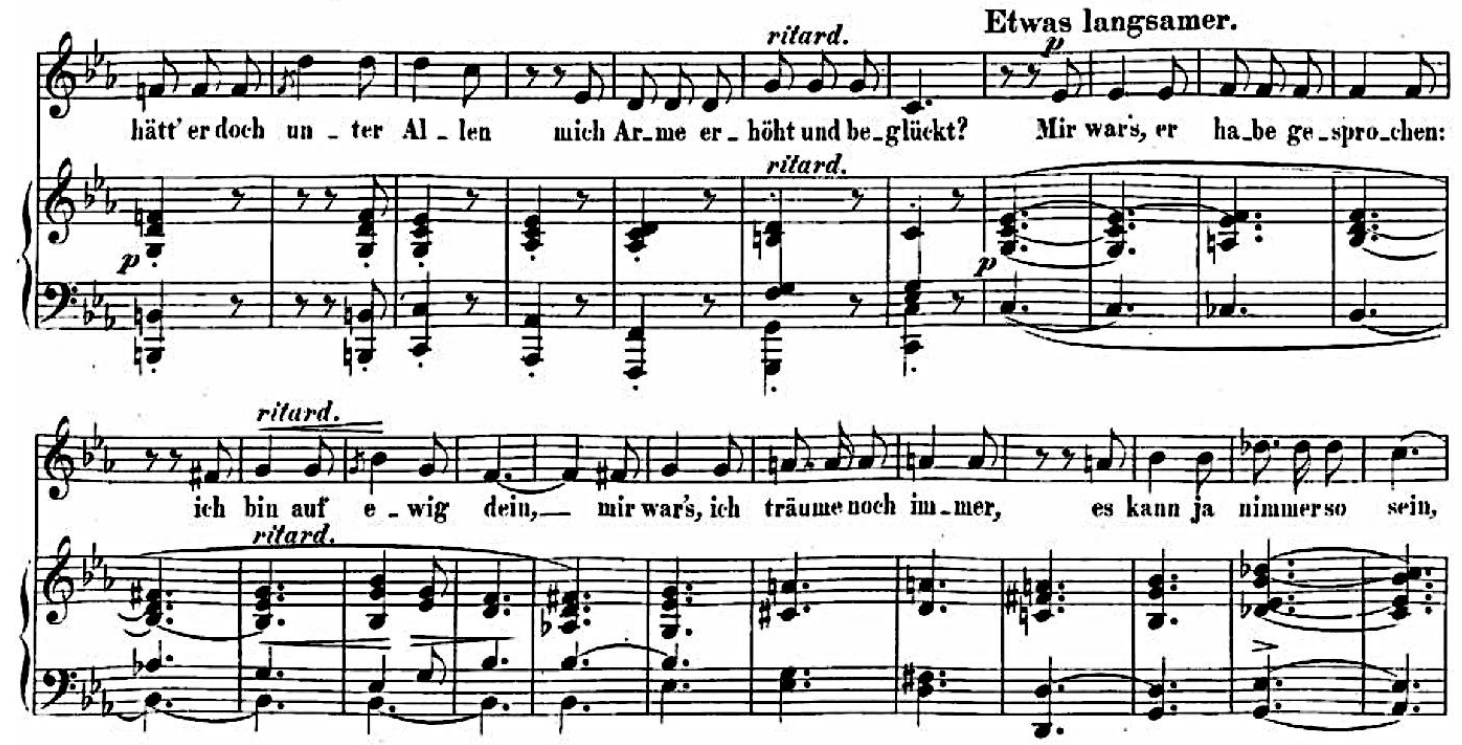

Figure 10. Fragment of 'Ich kann's nicht fassen, nicht glauben' (Bars 9 to 31)

The beginning of the third part of the song (see Figure 11) also starts on the weak beat as at the beginning, but the mood is different, and the tone colour should be 
enthusiastic and powerful. This is because the girl's unbelief is not the same as at the beginning. She actually believes it in her heart and sings about it with a sweet sense.
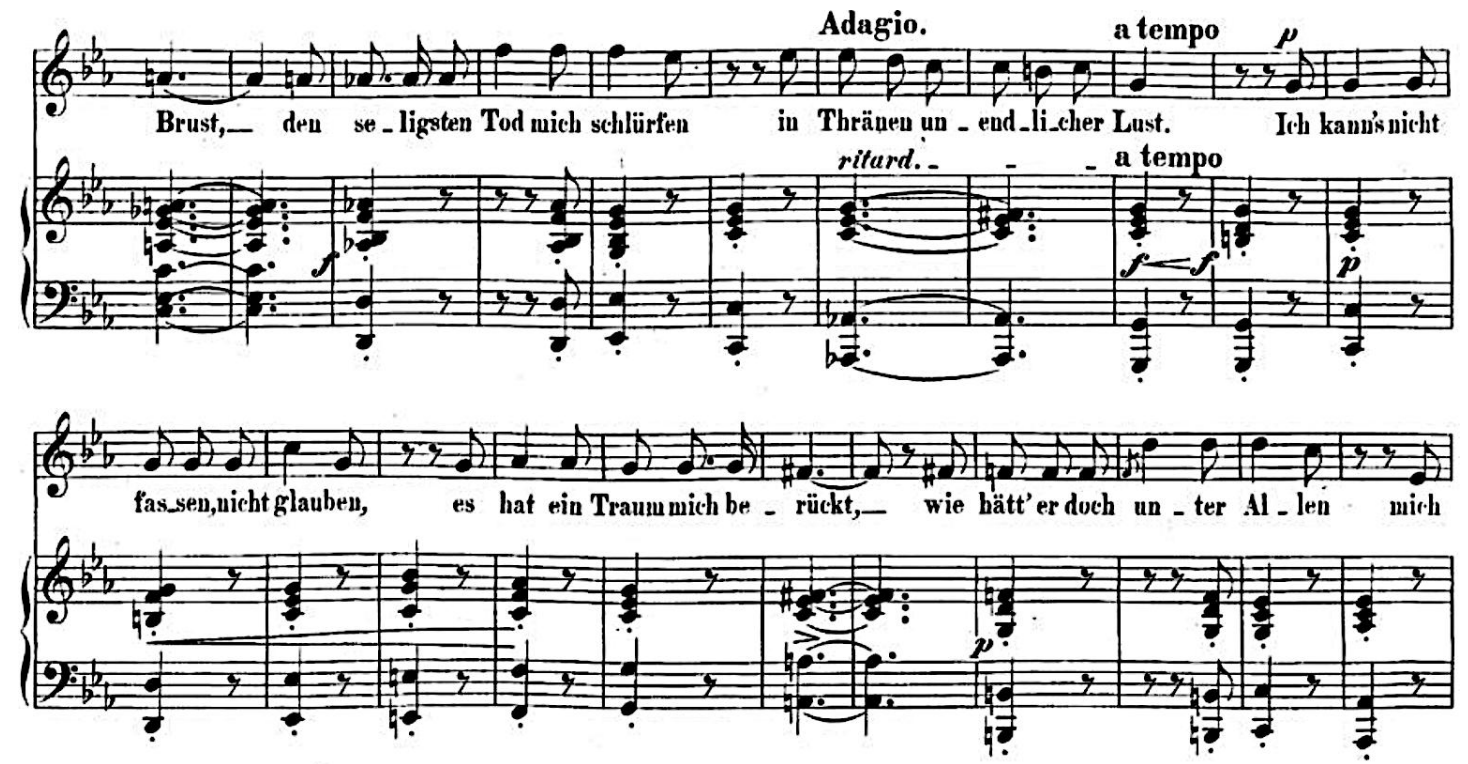

Figure 11. Fragment of 'Ich kann's nicht fassen, nicht glauben' (Bars 43 to 64)

\section{ii Before Marriage}

This part of the story mainly takes place in the fourth and fifth songs, showing the girl putting on the engagement ring and preparing for the wedding. As the girl's age increases, at this time she begins to mature rather than just being young and simple. She begins to look forward to the wedding with her lover and to show her longing for a wife. There should be more joy and excitement in the singer's voice since the girl has matured. In addition, it is necessary to pay attention to the fluidity of the sound, and the dynamic changes should be obvious. In the fourth song, the golden engagement ring is put on the girl's hand, and her dream becomes a reality. Schumann asks for piano and indicates the mood should be 'Innig' (intimate or thoughtful) at the beginning, so when the singer begins to sing this song she needs to use a soft sound, as if the girl's unresolved heart has finally come to a successful conclusion. 
The fifth song depicts the girl's wedding day, as her friends dress her up ready for the ceremony. Here the voice can reflect her uncontrollable joy, and perhaps her nervous excitement - the way people are often nervous on their wedding day. In the last part, the girl will say goodbye to her friends, and at this point her heart is sorrowful so the tone should be darkened. We can sing these phrases slowly with a weak voice, and use more chest resonance, expressing her melancholy before she quickly returns to the bright theme of happy emotions.

\section{2) Voice Characteristics of Psychological Changes}

\section{i Lovesickness and Joy}

In the first song in the cycle the maiden's yearning melody mainly appears in the first half of the song. The girl's emotions are mixed with the desire for love and the pain of missing him. In the first part (part A, bars 1-15), the singer can reach its climax through a slight increase in volume and sound intensity which highlights the importance of the lover in her heart. The dynamic in the second part is weaker than the first part, and it is more of a melancholy mood. Although the second song shows more praise for the lover, it also shows her feelings of missing her lover. However, in bar 57, the song repeats the melody of part A, and the emotions are different. The emotions in part A are clear and comfortable, expressing praise of her lover, while part A2 from bars 57 to 66 expresses the yearning for the lover. The singer's tone can be slightly dark, and she can sing slower and with a weaker sound in the final part, to express the melancholy emotions that the girl cannot satisfy.

The joyful mood in the song is shown in the wedding scene of marriage. The tone of the voice should be clear and enthusiastic rather than heavy, and the singing lines are soft and smooth. In the fifth song, it shows the excitement and joy of the virgin before she gets married. Performers should pay attention to the intensity of the sound used, 
and ensure the flow and smoothness of the phrasing used during the singing, which will make the mood of joy stronger.

\section{ii Sadness}

There are two places which show sad emotions for the character. One is in the B section of the second song. She is praising her lover, and she thinks that only the cutest girl deserves to share happiness with him, and that she will be very sad because she thinks that will not be her. The ritardando marks at bar 27 and bar 28 can express her inner sadness if the tone is made slightly dark as the melody is slowed.

Another place where sadness is expressed is in the fifth song, when the girl will be separated from her friends, because the wedding is about to start. The scale is going down smoothly, and the music transitions from A-flat major to the F-flat major, and the tempo gradually slows (see Figure 12), all of these varieties make these two bars are covered with dark colors. Singers can adjust the tone to slightly dimmer, which shows the girl's sadness when she leaves her friends.

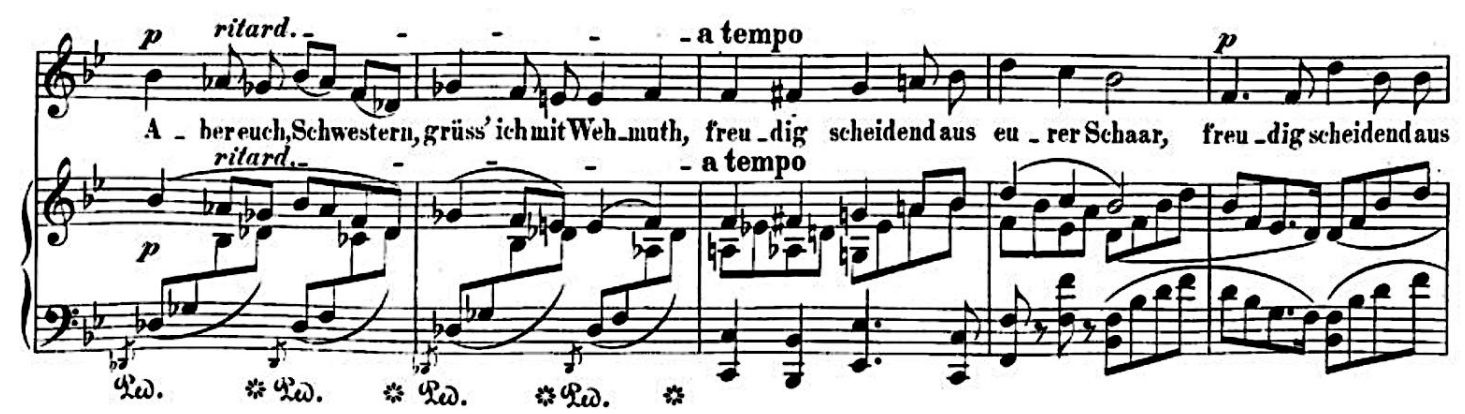

Figure 12. Fragment of 'Helft mir, ihr Schwestern' (Bars 41 to 45)

The character in Frauenliebe und -leben starts off as shy and even self-doubting when she meets her first love. However, when her lover asks her to marry him, and she gives her consent, her attitude is indeed firm and longing. I think this implies she has more agency than most nineteenth-century girls would have had: normally she might decide she wanted to marry someone, but in fact her father made the decision who 
was allowed to marry her. Moreover, this cycle is probably an artistic portrayal of Schumann's love life with his wife Clara, but Clara's father didn't allow her to marry Schumann at first. ${ }^{31}$ Therefore, compared with Schumann's real experience, the woman's experience of love in this cycle seems to be more beautiful and sweet. As Victoria Hart suggests, the cycle is not a derogation or glory of the traditional role of women, but Schumann's subjective desire to erotic and spiritual integration with Clara. ${ }^{32}$ However, at the end of the song cycle, the heroine loses her husband. Perhaps this also shows that in Schumann's impression, he had only happy memories of the time before he got married.

Schumann expresses the personality changes of the young girl by focusing on the piano accompaniment, and the psychological changes are in the accompaniment as well. This is the biggest innovation compared to previous composers. It is also different from Schubert's 'Heidenröslein' in the way the poetic texts used emphasise the metaphorical and emotional changes of the character. The varieties of the maiden character in this cycle are more complex and diverse. Schumann portrays the young girl's mood from longing, lovesickness, inferiority and sorrow to firm feelings and joyful welcome to the wedding by changing tempo, dynamic and tone. Although it is the male perspective of a female's experiences and emotions, Schumann's music provides a lively and rounded characterisation of the young girl in that we are exposed to a variety of emotions and a development of her psychological character and personality.

Chamisso's poetry may represent the attitude of men in nineteenth century towards women. However, Schumann strengthens the content of Chamisso's poems in Frauenliebe und -leben, and even the meaning he brought to the poems exceeds

\footnotetext{
${ }^{31}$ Carol Kimball, Song: a guide to art song style and literature, Hal Leonard Corporation, 2006, 80.

${ }^{32}$ Victoria Hart, "Equals in love:"Frauenliebe und Leben" reconsidered," PhD diss., University of California, Santa Barbara, 2004, 6-7.
} 
Chamisso's intentions. In this cycle, he delicately expresses the girl's inner activities and feelings in different steps (first meet, fall in love, engagement, marriage). In addition, the proportion of the piano part has increased, as well as the independence and blending of vocal and piano lines have enriched the means of expressing the artistic conception of poetry in music.

Moreover, I think the challenge faced by contemporary female singers when performing Chamisso's this poetry is to seek how to show the low-profile and humility of the girl with obedience and gentleness, because Chamisso's poetry reminds us that a woman who has found someone who loves her should be grateful to him. However, when describing this maiden character in the music, Schumann emphasizes that the singer who plays the virgin also needs to show the spirit of 'love is not asking, but dedication' on the issue of love. From this innocent feeling we can see a noble power of personality.

\section{Summary - Singing the Maiden's Experience of First Love}

We can see that these two works are placed together in this chapter because there are scenes in the song where girls and boys meet for the first time. While the scenes of the two works are similar, the girls in the two stories have very different attitudes towards the boy they meet. The wild rose in 'Heidenröslein' we can think of it as a tenacious girl. She does not obey because the boy likes her and wants to take her off. Instead, she is fighting for her destiny. She does not like the brutal boy, so even if she is picked, she will stab him. The girl in Frauenliebe und -leben falls in love with the boy she meets for the first time. Although in the several songs of this cycle, she also shows inferiority and disbelief, but when she is engaged, she is determined to be a virtuous wife and plan to spend the rest of her life with the beloved man. 
Both works divide the story into three stages: encounter (fall in love), contact (create conflict) and result (pain/happiness). The stages embody the function that lieder can clearly explain a story with these three parts in a song or cycle. The music tells the beginning of the story, its development, climax and constructs a rich dramatic effect. In 'Heidenröslein', since there are phrases in the verses which trace the dialogue between the boy and the wild rose, the singer can enhance the storytelling by using different tone for each of the two characters, especially the rose tone that represents the character of the young girl. In Frauenliebe und -leben, because the cycle highlights the psychological varieties of the girl, the singer can slightly increase the volume and sound intensity where the young girl is describing the happiness and excitement, thereby highlight the importance of the man in her heart. 


\section{Chapter Two - Sad Love: I miei sospiri - where shall I send my yearning cries?}

\section{'Die junge Nonne' by Franz Schubert}

'Die junge Nonne' (The Young Nun) is a lied based on a religious context and the text set by Schubert was a poem by Jacob Nicolaus Craigher de Jachelutta (1797-1855). Regarding the year of the song's creation, the soprano Sophie Müller recorded the following entry in her diary on May 3, 1825: 'After lunch Schubert came and brought a new song, Die junge Nonne; later Vogl came, and I sang it to him; it is splendidly composed' ${ }^{33}$ From this we can tell that the song was created in 1825 , which was only three years before Schubert's death.

This song has a manifestation of Christian elements. The female character in the song is a young nun who dedicates herself to the saviour. At the ceremony, she shows her love for God. The nun regards Jesus as her bridegroom and she finds peace in her devotion. They will effectively walk into the church together, and refuse everything in the world, finally the nun will achieve peace. This is a festival where the nun proves her true heart to the savior, but the song is full of melancholy atmosphere as well. The nun seems to have had an earlier love affair that caused her pain and sorrow, so she wants to escape from reality and has decided to obtain salvation and liberation by praying to God. Therefore, the heroine in 'Die junge Nonne' has a religious appearance on the basis of a secular female image. It implies that Schubert is profoundly influenced by Christian culture, from which we can also discover the core of Schubert's religious civilization in his lieder.

\section{Rich and Delicate Inner Changes}

33 Graham Johnson,1992, http://www.hyperion-records.co.uk/tw.asp?w=W2153. 
This is a very dramatic setting. The piano accompaniment shows a dark night with thunderstorms, and the singing represents the nun's inner monologue. She feels fear at the beginning, then longing for the saviour, and finally returns to peace. The song reflects the varieties of the nun's inner world which is rich and delicate.

The use of $\mathrm{F}$ minor in the opening prelude gives an oppressive atmosphere and the tremolo of continuous chords gives a feeling of restlessness (see Figure 1), and is the overall portrayal of the young nun's mood at this time. In the prelude, the left hand contributes the melody. After three bars of bass octaves, the left hand part enters the second small group's range. I think the bass octaves specifically represent the storm and thunder, and also lay the atmosphere where the song starts to be sorrow. The notes of second small group represent the soft and holy part of her heart, and they also represent hope. The duration of bass octaves and notes of second small group for half of the whole bar, which not only forms a sharp aural contrast, but also heralds the tangled pain in the young nun's heart contrasted with the hope in her heart. Through the prelude of these nine bars, the character of a young nun who is praying for atonement in depression and full of contradictions is displayed in front of us.

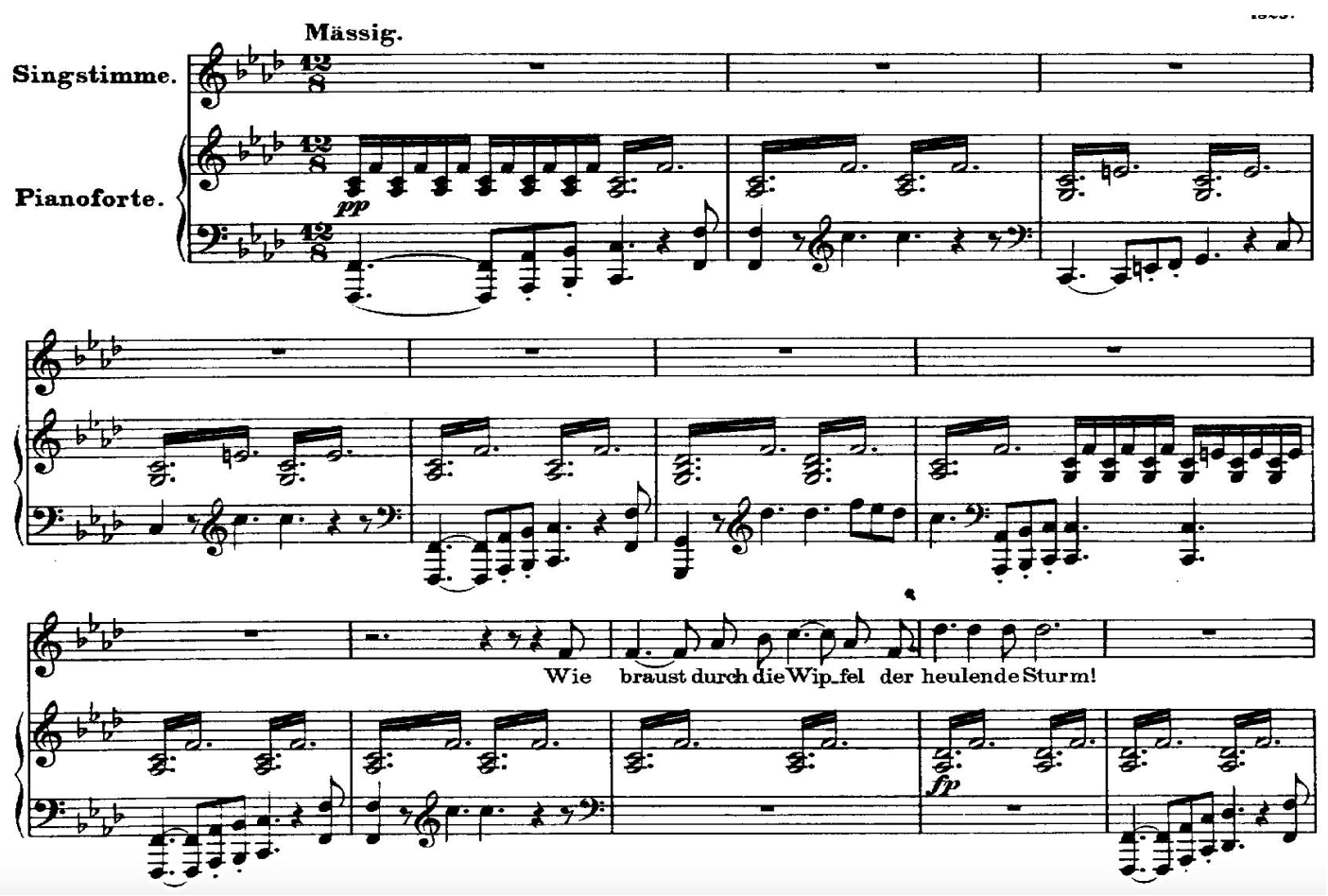


Figure 1. Opening section of 'Die junge Nonne' (Bars 1-12) ${ }^{34}$

In bars 9-21, the text directly impresses the scene of the screaming wind and the house trembling under the action of thunder and lightning, rendering the dull and dark atmosphere (see Figure 1). In the voice part, every phrase includes a six-degree leap immediately after the small ups and downs, which gives a feeling of emotional uplift. Although the content of the singing is to describe the stormy environment, I think the small ups and downs, also imply the hesitant and depressed mood of the nun. The six-degree leap represents the fluctuation of her heart, and there is a thought that wants to break through the darkness.

In bars 21-28, while the three semitones of the singing melody slowly descend, and the dynamic marks from piano to pianissimo to pianississimo make the volume softer, the tension of singing retains its intensity. It seems as though the young nun is in a trance alone, muttering to herself. She mutters: 'Und finster die Nacht, wie das Grab' (Dark night, like a grave). The duration of the word 'Grab' fills the entire bar, emphasizing its importance in this phrase. This is referring to the stormy night, that is happening in the present. Immediately after this she says this was how her life always used to be. That was her life outside the monastery - stormy and dark. The contradiction and conflict between reality and hope, tearing the mind of the young nun, so that her heart is full of depression and pain, and even has a feeling of mental disorder.

In bars 29-51, the appearance of A major in the right-hand tremolo leads to a shift in key to B major, but after only two bars, it enters the minor again. The major that appears briefly, I think is like the little hope in the nun's heart, this hope is fleeting. After the hope, she is involved in the pain of this past life once again.

\footnotetext{
${ }^{34}$ The figure is taken from

https:/imslp.simssa.ca/files/imglnks/usimg/3/38/IMSLP16395-SchubertD828_Die_junge_Nonne.pdf. All the other figures for this song are from the same edition. 
In bars 52-68, the key here turns into a warm F major, and the melody is still the first bar of the prelude as the dominant motivation. Then the melody continues to expand afterwards. It shows that despite being caught in the storm now, the nun is not afraid. She is determined to dedicate herself to God in the convent, so as to find spiritual peace and be "isolated". In reality, the dedication ceremony of the nuns centuries ago was similar to a wedding. Therefore, the bridegroom in the text refers to God. The young nun in the music is like the nuns of the Middle Ages, who devoted their lives to God and their faith, as well as giving up worldly values and their sense of self-importance. ${ }^{35}$ The text in bar 59-60 is: 'Der ewigen, ewigen liebe getraut' (believing that sincere love will never change hearts). This sentence shows that the nun believes that life will change from now on. At this time, she seems to forget that the surrounding storm is blowing her, because her heart has lit a flame of hope, which is warm. The slow halftones in the bar 62-64 continue to move upwards, indicating the nun's hope of the flames which are burning. She is about to rush out of the darkness, she will approach God and rekindle her expectations for life. The nun needs the faith in her heart to save her from the world and sublimate her soul.

In the bar 75-83 (see Figure 2), the text is: 'Es lockt mich das süße Getön' (this sweet and warm tone). This sweet and warm tone refers to the two dotted crotchets of second small group in the left-hand piano part. They represent the bell which is ringing in the tower (which is presumably the bell that is rung to call worshippers to the church, and in this case means the ceremony of 'marriage' (the nuns taking their orders) is going to begin soon. At this time, the higher bell's sound seems to give the young nun confidence, encourage her to break through the cage of suffering, and fill her heart with hope. The whole song reached its climax here, and the young nun is about to follow the bells and climb up to gain a state of freedom.

35 "Medieval Nuns," Lords and Ladies, http://www.lordsandladies.org/medieval-nuns.htm. 

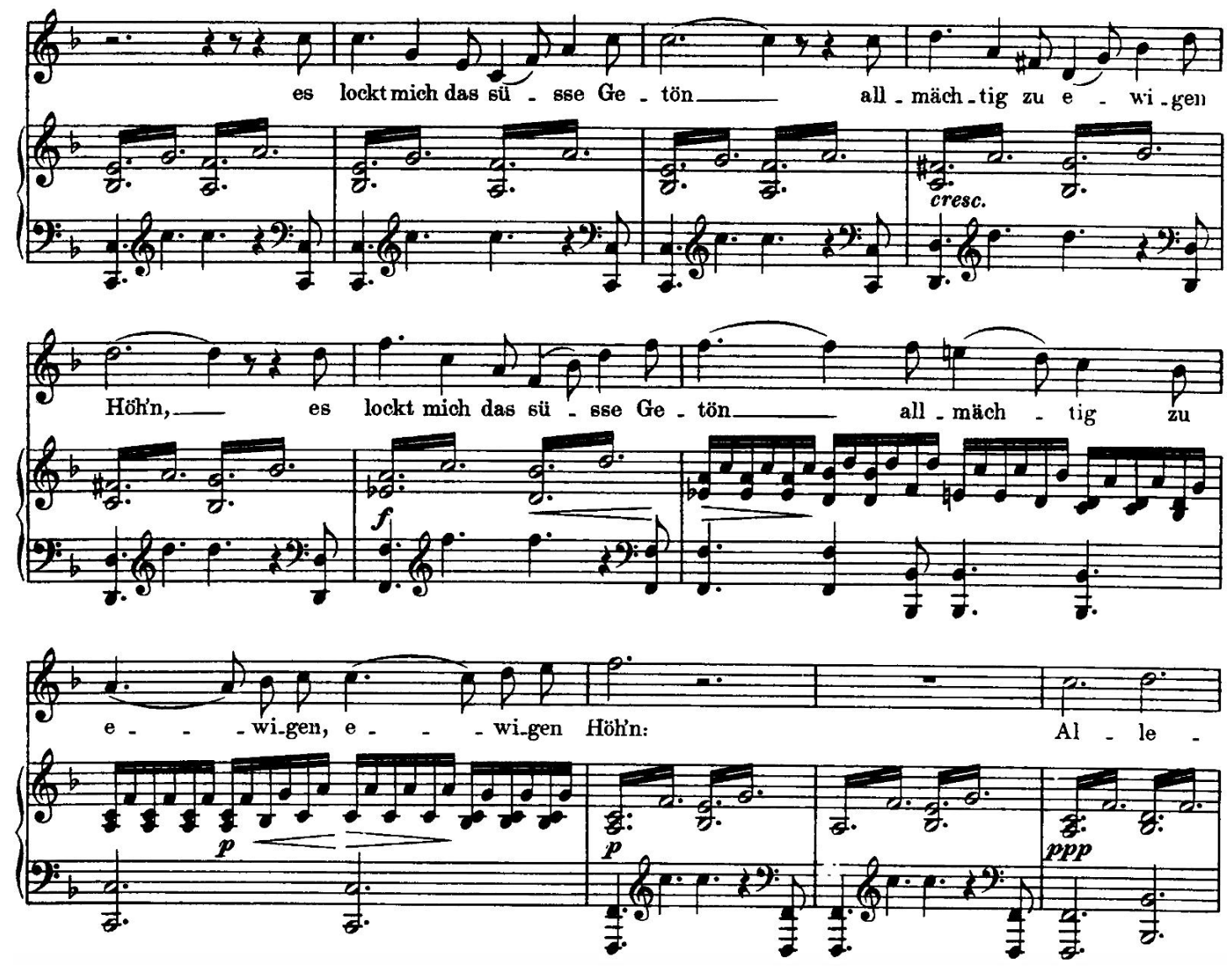

Figure 2. Ending section of 'Die junge Nonne' (Bars 75-83)

In bars 84-94, the singer sings 'Alleluia' towards the end. The nun sees God through her prayers. She is having a peaceful conversation with God. She conquers all the complexity in the world. It seems she finally greets the faith in her heart and her soul is sublimated. The left-hand of the piano part still continues the combination of the bass octave and the notes of two-lines octave. At this time, it is no longer a storm, but more like God is coming to the nun. The bells in the distance solve all the storms and sufferings she experienced in this earthly world. She returns to the saviour and everything seems to be solved and resolved in 'Alleluia'.

\section{Interpretation of Singing}

1) Emotional Variety

'Die junge Nonne' describes a nun's intense emotions that are about to collapse in the stormy night, and she wants to get away from the turmoil of life in the uncloistered 
world and achieve inner peace as well as soul release from spiritual union with God. When she hears the bell ringing in the ceremony, she feels so excited, as if she has been saved and is in peace, until finally returns to calm. This requires the singer to accurately show her inner emotional transformation in just one song. I think that before singing a song, we should familiarize ourselves with all the dynamic marks in the music. Forte can express many kinds of emotions. Similarly, there are lots of pianos. They are not just the difference between loud and soft. Forte can be a happy loud voice, a sad loud voice, or an angry loud voice. ${ }^{36}$ Therefore, only when we clearly understand the emotions expressed by the dynamic marks of the song, and understand why she has such emotional changes in the mind consciousness, can we accurately express the nun's emotional changes through voice.

\section{2) The Harmony of Singing and Piano Accompaniment}

In terms of the characteristics of lieder, these songs emphasize the perfect combination of singing and piano parts that shapes the image of music together. ${ }^{37} \mathrm{In}$ the process of singing, the singer should take care to listen to the piano part. The piano part will play a lot of prompting functions for the singer, such as stabilizing the tempo, tonal transformation to prompt the singer to change the mood. The accompaniment also strengthens the effect of an emotion that is in the vocal part. Sometimes singers forget to listen for this and do not allow it to come through, or they forget that the piano has a 'voice' too and they might learn more about the complexities or details of the character by listening to what the piano is playing. Perhaps the character is feeling more than one emotion at once and the piano helps to show that.

The octaves of the left hand in the piano part of this song are like the thunder in the

\footnotetext{
${ }^{36}$ Patrik N. Juslin, and John A. Sloboda, Handbook of Music and Emotion: Theory, Research, Applications Oxford: Oxford University Press, 2011, 368-370.

${ }^{37}$ Katlin Harris, "Death, the Trout, and the Maiden: Schubert's Instrumental Interpretation of His Lieder," https://www.methodist.edu/wp-content/uploads/2018/09/mr2017_harris.pdf, 41.
} 
stormy night described in the poem. If the voice is to appear in the thunder, it must be concentrated and relatively strong. However, we should not sing too hard and too intensely, but control our emotions. In bars 75-83 (Figure 2), the singing part and the piano part have a dialogue, as can be seen in the figure below. In the left hand, the dotted crotchets echo the voice part, prompting the singer to push the whole song to the climax here, so that the young nun can break the bonds of earthly life and achieve spiritual freedom and peace.

\section{3) Creating the Nun's Character}

This song is dramatic, and the singer needs a full passion to show the nun's inner struggle, so singing this work requires a sense of conflict. The nun has been fighting against the storm. She hopes to have a different life, so when singing this work, the singer needs continuous strength and power. In the singing process, the singer needs better endurance, and the support of the breath is also continuous. Most of the phrases in the work start with an unstressed quaver. In order to express the nun's anxiousness, the quaver here should be sung shorter, bringing strength to the next bar. The voice does not need to be too loud, but needs to express a tense emotion, as if the nun has always had a brave emotion in the face of the storm and has said: "I am not afraid". The whole song should maintain tension when singing, and keep the pitch position and state all the time, so that we can express the heart of the nun against fate.

Schubert's 'Die junge Nonne' captures a moment in which under the appearance of religious baptism, the secular subconsciousness is still agitated. Nuns refuse material luxury and contact with the opposite sex, as well as restraining their emotions and desires. ${ }^{38}$ However, young nuns cannot transcend worldly desires and emotions in a short time. As a kind of humanistic care, Schubert creates a nun who has the feelings of worldly people: depressed angry and struggling, but also has a beautiful longing

\footnotetext{
38 Jo Ann McNamara, Sisters in Arms Catholic Nuns through Two Millennia 1st Harvard University Press paperback ed. Cambridge, Mass: Harvard University Press, 1998, 5-6.
} 
and yearning for a peaceful life. This emotion makes her breathless, but in the end she gains inner peace and redemption with the help of God. Therefore, when performing, the singer should try to present to the audience a young nun who still has the ambivalence of secular emotions. It is necessary to embody the identity of nuns, but also to express the inner conflicts of secular girls, and at the same time to show the young nun's attachment to and respect for God.

In this work, the image of the nun created by Schubert is the product of the combination of universalization and religiousness. The religious female character in 'Die junge Nonne' is secularized without losing the sense of sacredness. The characters are eager to redeem in front of God. The young nun has experienced pain and suffering in reality, but spiritually, because of the sustenance of religious belief, she has been released by her soul. The appearance of the Alleluia prayer has released the character's inner depression, as if all unsatisfactory things have disappeared. Therefore, the young female character in this song is holy, but at the same time they have the characteristics of 'universalization'.

\section{'Eccomi in lieta vesta...Oh! quante volte' (from Vincenzo Bellini's I Capuleti e i Montecchi)}

I Capuleti e $i$ Montecchi is an opera by Vincenzo Bellini to the libretto by Felice Romani (1788-1865). The creative inspiration may come from the story Romeo and Juliet by William Shakespeare (1564-1616). However, the specific source of the libretto for this opera was the one written for an earlier opera, Giulietta e Romeo, created by Niccolo Zingarelli (1752-1837) in $1796 .{ }^{39}$

\footnotetext{
39 "Premiere - I CAPULETI E I MONTECCHI - Opera by Vincenzo Bellini," Sofia Opera and Ballet, https://www.operasofia.bg/en/news-and-events/item/8181-premiere-i-capuleti-e-i-montecchi-opera-by-vincenzo-b ellini.
} 
In this opera, Giulietta lives in medieval Europe. Although Giulietta is a noble in the opera, she is a girl who calls for liberation of personality, anti-religion and anti-feudalism. She hopes to pursue independent love, desires freedom, and wants to break free from her family, but she cannot compete with the powerful family forces. Because at that time, the noble class ruled society, in order to consolidate their own interests, the aristocracy continuously exploited citizens' rights and interests. In addition, in order to compete for land and power, conflicts of interest among nobles were common. ${ }^{40}$ In a sense, the conflict between the Capuletti family and the rival Montecchi family is a struggle between two social forces. However, Giulietta ultimately lacks the power to gain what she pursues, so we will see in the opera that the ending is doomed to failure. Under such feudal constraints, Giulietta remains firm in her love, and she looks forward to Romeo's appearance to reverse the situation. This "firmness" represents a deeper interpretation of Giulietta's sentimental emotions and also brings sadness to the image of Juliet. Below I will discuss her character as shown through the musical elements used by Bellini in the aria 'Eccomi in lieta vesta ... Oh! Quante volte'.

\section{Background and Introduction to the Character}

'Oh! Quante volte' is the aria when Giulietta makes her debut in the first act and second scene of I Capuleti e i Montecchi. Prior to this Giulietta hears that she is going to be married to Tebaldo, and she looks at the wedding dress on the ground in the room with sadness. She has fallen in love with Romeo, who killed her brother, and she feels very conflicted, pained, and helpless.

For many young women, there is an expectation that putting on a beautiful wedding dress and stepping into the hall of marriage will be the best moment in her life, but in this instance, Giulietta likens herself to a victim on the altar. She regards the beautiful

40 Michael Mann, "Ruling class strategies and citizenship." Sociology 21, no. 3 (1987): 339-344. 
wedding as a funeral. Giulietta is so reluctant and helpless, she only hopes to let the breeze blow to Romeo she loves, and let Romeo take her away from here. Although Giulietta is suffering from the feudal family-arranged marriage, she still insists on loyalty to Romeo and awaits his rescue. She likens Romeo to the light of the sun, Romeo is like a lighthouse in her heart, which can illuminate the darkness she is in at this time. She also likens the breeze around her to Romeo's breath, reflecting the indescribable feelings she has for Romeo.

\section{Music Analysis}

The aria's music comes from Bellini's first opera Adelson e Salvini. ${ }^{41}$ The song is a romantic aria, its music is elegant and beautiful, with dreamy colours, and the musical lines are active and delicate. The prelude to the song reflects Giulietta's inner uneasiness, and the use of descending scales seems to suggest the beautiful Giulietta is slowly moving towards the audience from far to near.

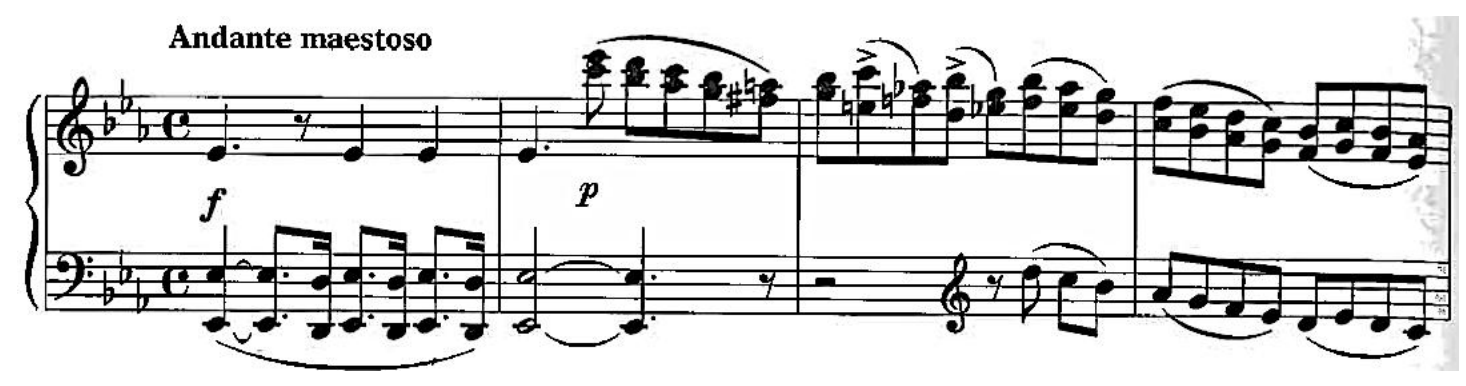

Figure 3. Fragment of 'Oh! quante volte' (Bars1-4) ${ }^{42}$

When the song goes to the middle of the recitative part, there is the same musical motive as the prelude. This part of melody is like imitating Giulietta's sigh, expressing her inner helplessness and sadness.

\footnotetext{
${ }^{41}$ Stanley Sadie, and J. Tyrrell, "Dictionary of music and musicians," 2001, 201.

${ }^{42}$ The figure is taken from Robert L. Larsen, Vincenzo Bellini, Georges Bizet, Alfredo Catalani, Gustave Charpentier, Antonín Dvořák, Christoph Willibald Gluck, et al, "Arias for soprano, Volume 2 " New York: G. Schirmer, 2004, 108-114. All the other figures for this song are from the same edition.
} 


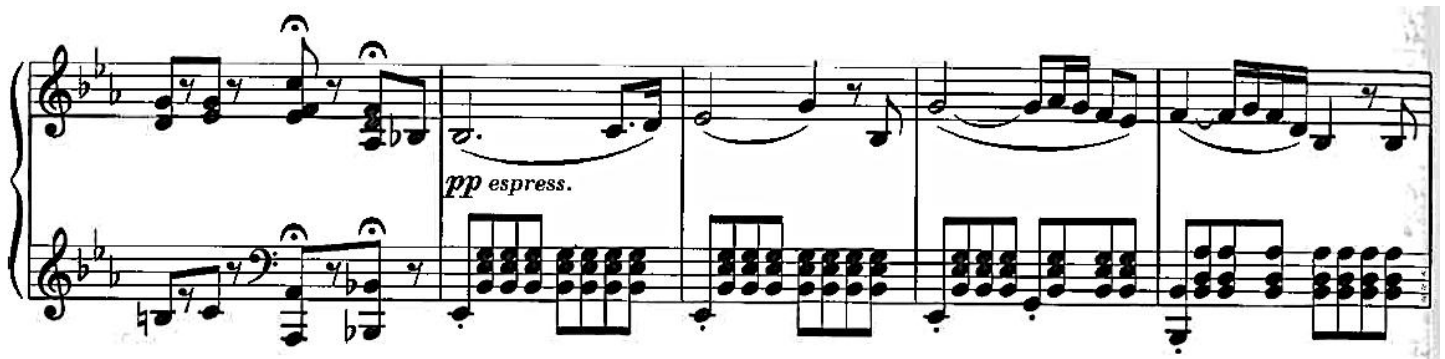

Figure 4. Fragment of 'Oh! quante volte' (Bars 5-9)

In the recitative, instead of saying that Giulietta is singing, it is better to say that she is speaking to her heart. The melody and accompaniment are like a form of speaking and answering, listening to the most truthful thoughts in her heart through her own telling.

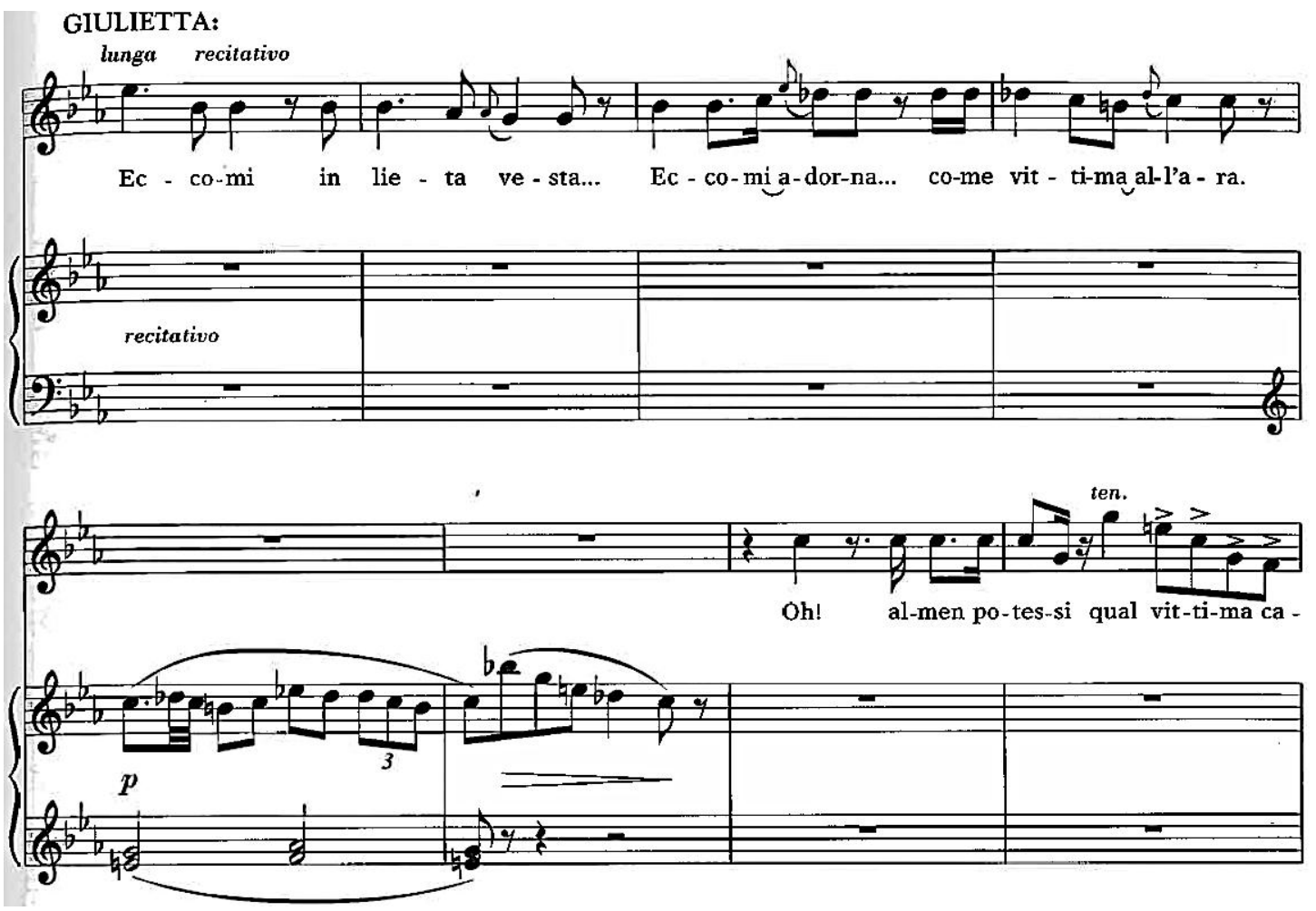

Figure 5. Fragment of 'Oh! quante volte' (Bars 24-31)

After Giulietta has been thinking these things, she feels very sorrowful, so she sings 'flame, blazing fire, this fire will melt me all' ('Ardo ... una vampa, un foco Tutta mi strugge'). However, she seems to be an incapable of recovering from her sorrow, and she says: 'it is like the wind blows gently, and it is futile to seek comfort from me. In 
vain I call on the winds to cool me' ('Un refrigerio ai venti io chiedo invano'). Then the accompaniment follows the breeze with beautiful and smooth arpeggios.

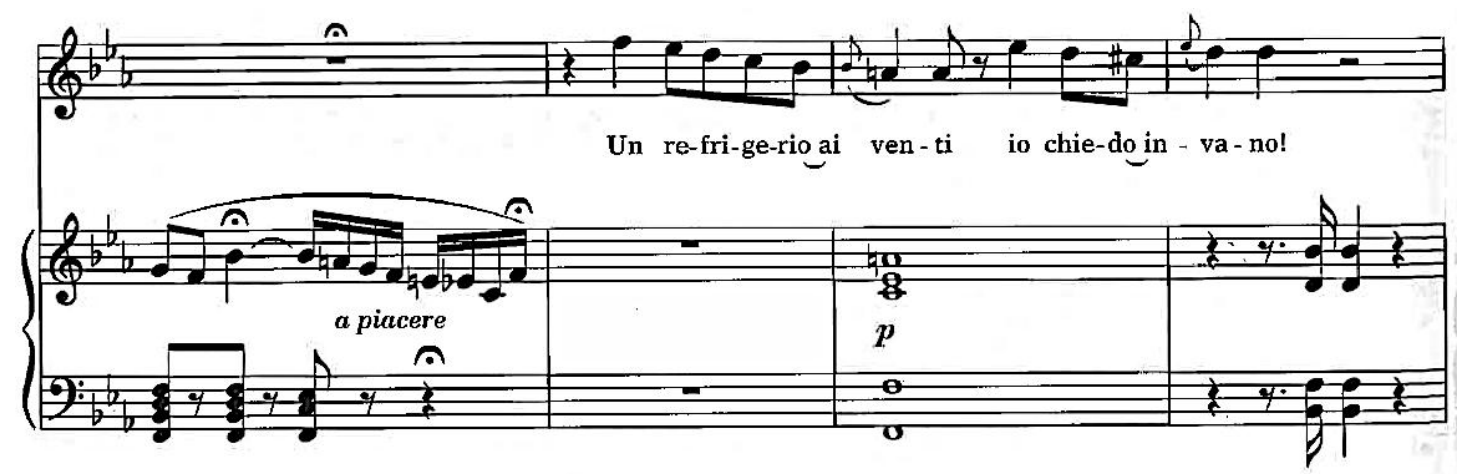

Figure 6. Fragment of 'Oh! quante volte' (Bars 52-56)

After an interlude, the following changes occur in the aria part. 1) The key changes from $\mathrm{E}$ major to $\mathrm{G}$ minor, so the minor key sounds more dark. Giulietta's tone in the recitative is questioning, complaining, and unwilling, but when the music turns into $\mathrm{G}$ minor, this shows more sadness, begging and helplessness. 2) Accompaniment textures often use broken triplets and arpeggios, and the start of phrases often use partial measures. It is more like Giulietta uses a helpless tone to beg from the heart to the heavens. 


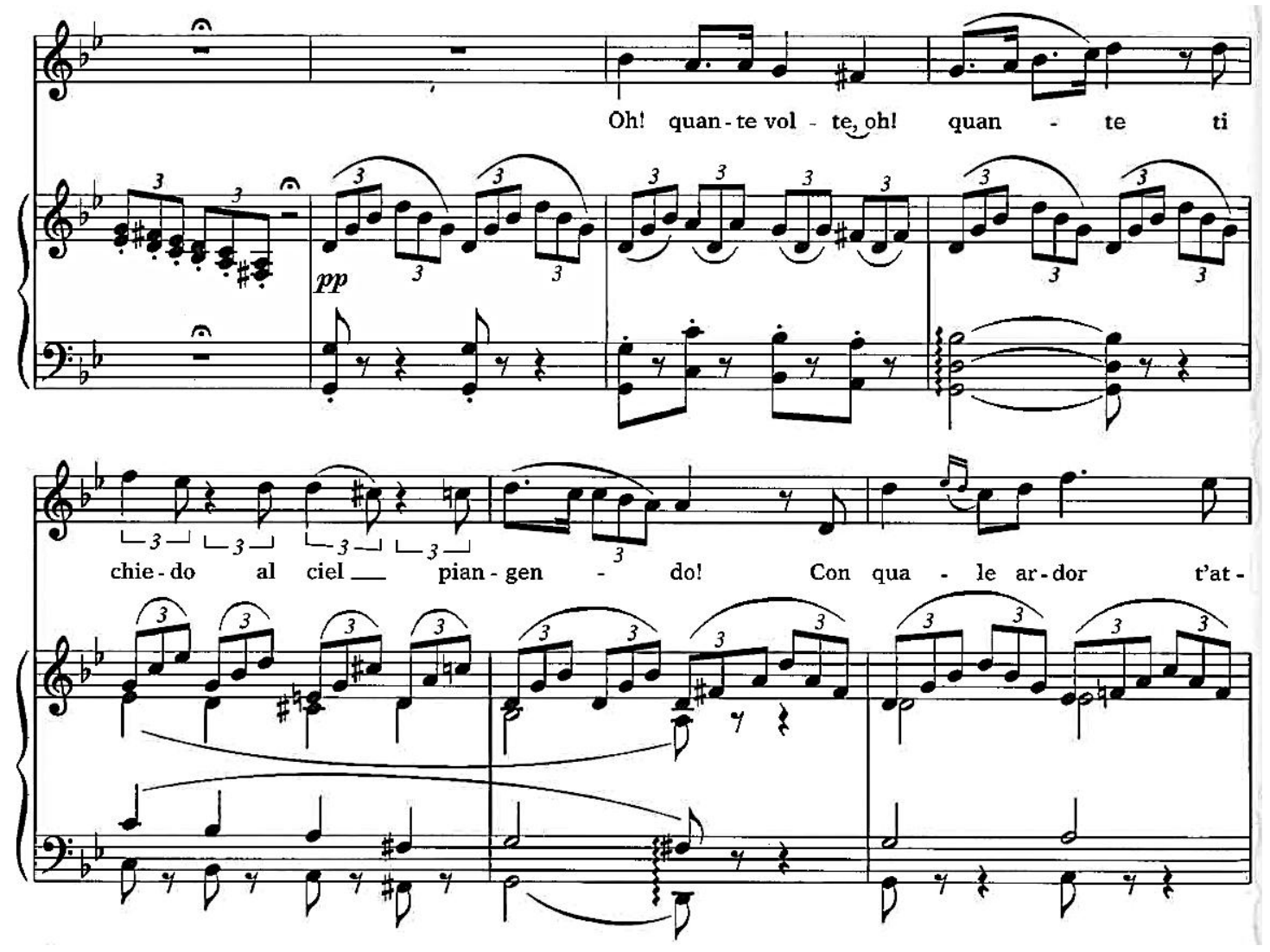

Figure 7. Fragment of 'Oh! quante volte' (Bars 74-80)

At the end of the song, octave staccato chords are used to make a descending progression, just like a brief relief from the heart after venting grievances. The dynamic gradually decreases from piano to pianissimo, which gives a feeling of escaping. 

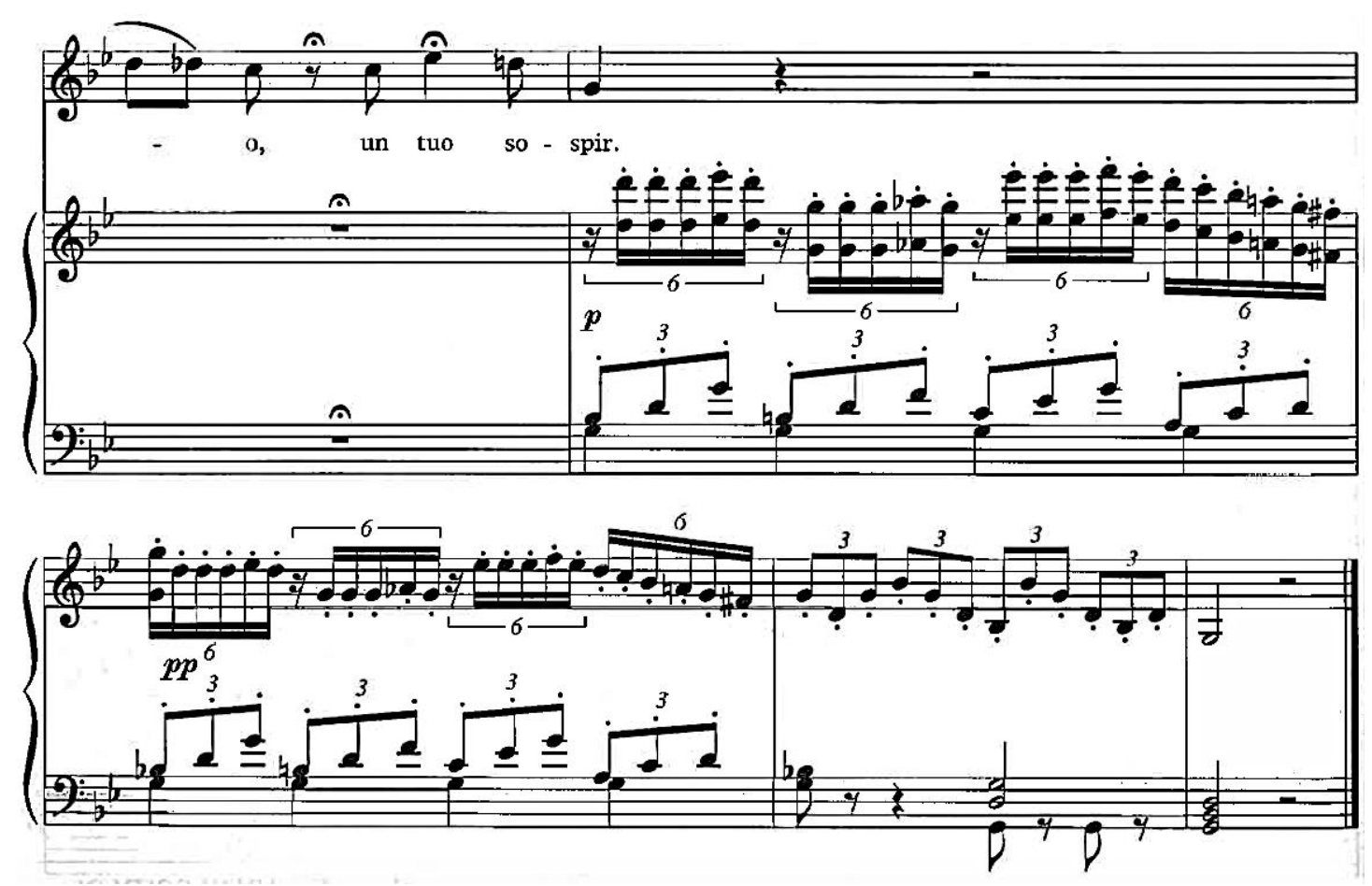

Figure 8. Fragment of 'Oh! quante volte' (Bars 101-105)

\section{Singing Characteristics}

Giulietta is in the room alone. At this time, she is facing either a compromise of feudal secularism or a brave choice for love. Her heart is full of sadness and helplessness. Because it is a monologue to the heart, the singer does not need to have too much direct communication with the audience when singing. The performer can sing quietly, and an emotional voice can be used to impress the sense of the young woman's feelings on the audience.

1) Emotion

When Giulietta appears in the opera singing this aria, she is already a tragic girl who is obsessed with love. Bellini arranges Giulietta's appearance in this way, without any preparation of the tragedy that has already been brought about, and directly enters the theme of the tragedy. Therefore, we should pay attention emotionally when interpreting Giulietta: 
i Helpless for not being able to have any control over who she marries. In the recitative, Giulietta compares herself in a wedding dress to a sacrifice dedicated to the gods, and has repeatedly stated that she is suffering at this moment. She is already full of sweetness with Romeo, but she is forced to marry Tebaldo, whom she did not love. Therefore, her heart is full of helplessness and entanglement.

ii In the face of the strong pressure of the feudal family, Giulietta still guards the firmness of love. 'Emotional firmness' is the singer's deeper performance besides Giulietta's helpless interpretation of sadness. ${ }^{43}$ Giulietta, who is about to wear a wedding dress, has not given up her love for another man. She still hopes that Romeo will appear and change the situation. She continues to call Romeo in her heart. Therefore, we cannot make Giulietta too pessimistic in her interpretation. At this time, she still has faith in her heart and thinks that the result can be changed. Therefore, our interpretation of Giulietta should have a firm side and an optimistic side. The singer can sing in some cadenza phrases with dynamic changes, and extend the highest pitch duration to express Giulietta's firm belief that Romeo will come back to find her. In addition, the performer does not need too many portamentos between notes during singing, because that would make the heroine less firm. We can sing out the pitch of the notes directly.

iii Missing and relying on Romeo. Giulietta likens Romeo to the brilliance of the sun, and likens the breeze to Romeo's breath, exemplifying her incomparable longing for Romeo. She complains: 'how many times ... so eagerly waiting for you, my mind is deluded' ('Con quale ardor t'attendo, E inganno il mio desir'). Although Giulietta's mood is disordered at this time, when she remembers Romeo, she thinks that all problems will be solved easily. It can be seen that she has a deep sense of dependence on Romeo. Therefore, when singing this kind of sense of dependence, the singer's

${ }^{43}$ Michael Mann, "Ruling class strategies and citizenship," Sociology 21, no. 3 (1987): 345-350. 
voice can be more smooth and softer. We can even add some body movements to express the way Giulietta is missing Romeo. For example, embracing ourselves with both hands, as if Romeo is embracing Giulietta.

\section{2) Processing Singing Skills in the Music}

i Dynamic Processing.

The first skill required is "f-p-f" singing. In the same phrase, the dynamic changes from forte to piano and then forte, such as the first phrase in the aria part 'Oh! quante volte, oh! quante (ah, how many times)' (see Figure 7). This phrase can be "f-p-f" in terms of pitch or emotional catharsis. In addition, the same applies to the cadenza of the ending sentence, the quietest tone of the whole phrase stays at the highest $\mathrm{c} 3$. On the one hand, this kind of processing can show the singer's skills. On the other hand, its sound effect is leisurely and ethereal, which can better grasp the audience's heart and arouse spiritual resonance.

The second vocal challenge is the obvious contrast between the strength and weakness of the two phrases. A lot of phrases in the aria form echoing responses, such as the last two phrases of the recitative, 'Dove, dove inarti, dove' ('where, where should I go'), 'I miei sospiri' (my sighs)? She keeps asking where she should go, and then gives her answer: she has nowhere to go, but can only sigh. In the previous sentence, Giulietta complains, venting her inner confusion, and then curls back into the depths of her sad heart with helplessness. Therefore, when the singer sings the previous sentence, the tone is strong and the dynamic is forte. When the second sentence is sung, the dynamic becomes piano and the tone weaker.

ii The Relative Freedom of Tempo.

When singing Bellini's work, we should have flexibility in tempo as well as rhythmic accuracy. When singing this aria, it is necessary to have the rubato of emotional 
cathartic phrases, such as cadenza phrases and phrases with free pauses. Moreover, it should also have a sense of internalised energy that reflects the inner excitement, such as constant inquiries in the recitative 'Ove sei tu, Romeo (Romeo, where are you)'? When singing 'Romeo', the tempo is faster. On the one hand, it reflects Giulietta's anxiety in seeking her lover, and on the other hand, it shows her yearning for him.

In this aria, although the setting is in medieval times, Giulietta embodies a tragic girl in an Italian opera of the nineteenth century. The tragic colour of Giulietta's role has been laid out from the beginning, and her appearance is an image of love, sadness and pain. Bellini makes such an arrangement for this character, so that the audience can see the tragedy of this work directly from the beginning without rendering the previous action that led to it.

When Giulietta puts on her wedding dress yet has not completely abandoned her feelings for Romeo, she still keeps calling and looking forward to Romeo in her heart. As a young woman in the twenty-first century, I can easily understand Giulietta's reaction. I think if I were her, I would not like to succumb to this marriage and accept the arrangement. I would appeal to my father and even run away from the family as well as start a new life with my lover. I believe that the singer must understand that Giulietta still has a hint of reluctance to admit her fate in her grief. Performers should pay attention to show these subtle differences, so that the singing has a rich sense of the layers of emotions the character is experiencing, and also makes the expression of the characters' emotions more abundant and accurate. Romeo's appearance in the text as a bright sunlight shining on Giulietta can be reflected in the tone used by the singer. It can be seen that Giulietta still appreciates the love of Romeo when she is anxious. Here, the singer can show the character's unfailing personality characteristics, while expressing her urgent and slightly romantic feeling. 


\section{'Ah, non credea mirarti... Ah! non giunge' (from Vincenzo Bellini's La Sonnambula)}

In operas of the nineteenth century, depictions of the virgin heroine often are found in a pastoral setting, with a mountainous location being particularly common. From the 1820 s until the beginning of the twentieth century the story often occured near the Alps, with sky, snow, and air as innocent as the plot's female protagonists. ${ }^{44}$ This is how La Sonnambula is set. The plot starts with the pure Alps in the background, and the metaphor stands for Amina as a pure girl, and her pure love. ${ }^{45}$ In order to make the whole story more authentic and credible, the libretto by Felice Romani (1788-1865) features a condition that was just beginning attract attention from medical practitioners in Europe at that time-sleepwalking - as the element of the opera on which the plot turns. As Riva et al note, 'Somnambulism was still a mysterious condition during this time, since its pathogenesis was unknown' ${ }^{46}$ Bellini uses a variety of music forms and techniques to shape Amina's musical character so that the character of Amina is both simple and beautiful within the romantic melody, but also full of strange charm because of her dream-like sleepwalking.

\section{Technical Difficulties in Singing}

When I sing this aria, there are several vocal technical difficulties that need to be overcome through practice. These difficulties can also be called characteristics because they constitute the images of Amina. She is a young unmarried woman with a complex and diverse personality. Amina's unconscious and heartbroken appearance while sleepwalking is able to be emphasised through expressive use of the legato in the cavatina and the cadenza in the cabaletta can express the excited image of a young

\footnotetext{
${ }^{44}$ Emanuele Senici, Landscape and Gender in Italian Opera: The Alpine Virgin from Bellini to Puccini, New York: Cambridge University Press, 2005, 2.

45 Emanuele Senici, The Alpine Virgin from Bellini to Puccini, 23-24.

${ }^{46}$ Michele Augusto Riva, Caterina Mazzocchi, Giancarlo Cesana, and Stanley Finger, "'Il Sonnambulo'by Michele Carafa: A Forgotten Romantic Opera with Sleepwalking," European neurology 76, no. 5-6 (2016): 210-211.
} 
girl who has regained love. Below I will focus on these two challenging technical features of the piece to explore their purpose and expressive possibilities.

1) Legato

In 'Ah, non credea mirarti', there are a lot of legato phrases, with the middle pitch range and the dark melody lines, so that Bellini creates a melancholic atmosphere. When I am singing the legato melody, I find that the crescendo-decrescendo shaping of the long phrases commonly found in Bellini's writing is a detail that singers need to pay special attention to, because performers need to rely on the pressure of the breath to maintain control over strength of the sound. Therefore, whether it is for the singing of long legato phrasing or the processing of dynamics, the emphasis should be on the control and use of breath.

In addition, forte is relative to piano. If either of them disappears, the other one has no meaning, or existential purpose. Therefore, when dealing with the dynamics of a song, we should follow this pattern. When we sing more quietly at the beginning, it can leave us more room to become stronger in the later music. Similarly, we can sing more loudly at the beginning to show the decrescendo effect. In the creation of lyrical arias, Bellini often uses continuous crescendo and decrescendo within a long phrase. For example, in the first phrase, the two bars can be performed crescendo and decrescendo respectively. We need to handle such variety in dynamics, this is because we cannot expect to show rhythmic clarity without dynamic contrast. 

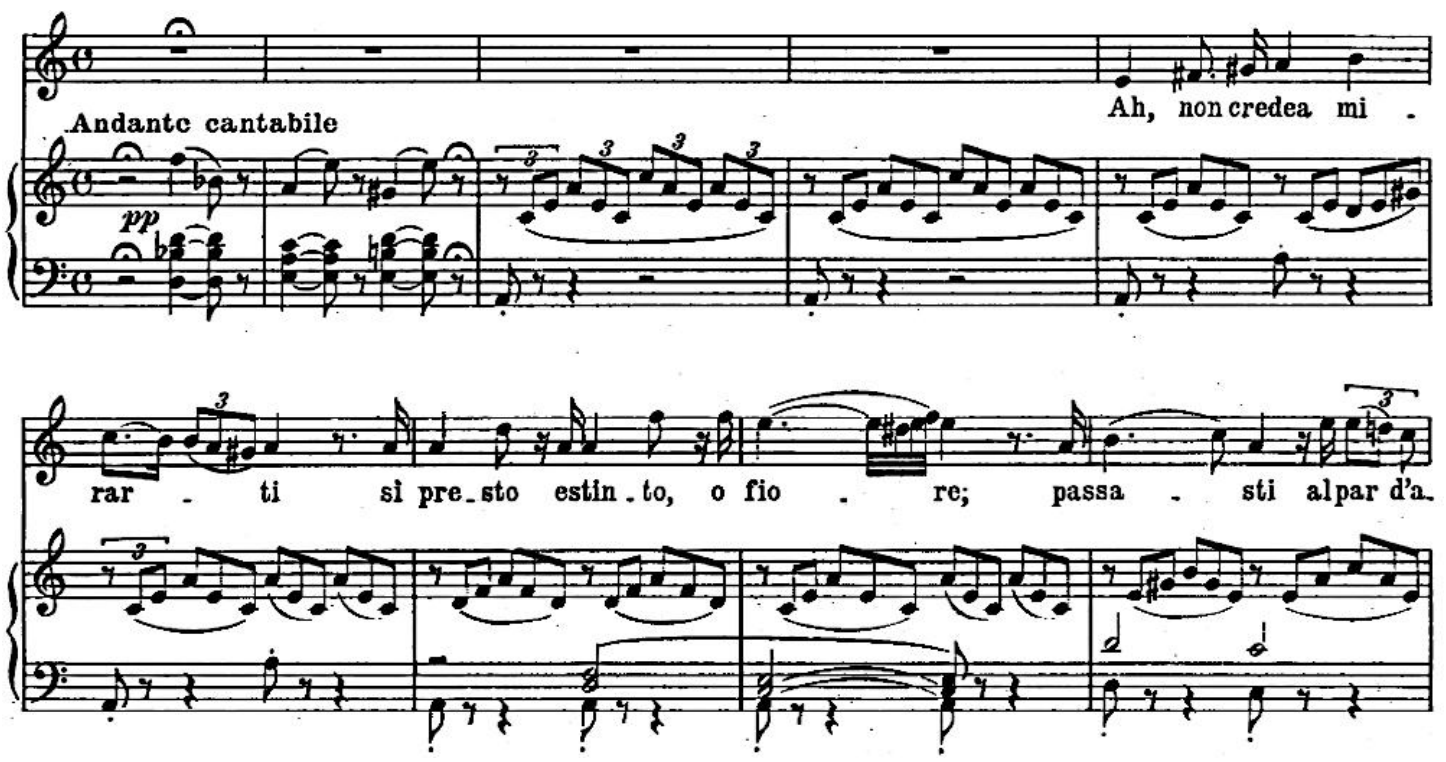

Figure 9. Fragment of 'Ah! Non credea mirarti' (Bars 1-9) ${ }^{47}$

2) Cadenza

When the work transitions from 'Ah, non credea mirarti' to 'Ah! non giunge', the interlude sets up a faster speed and the bass part of the accompaniment has fast repetitions of chords, like a quick heartbeat to express Amina's regained love. Also, a large number of cadenzas are added to this song, which also reflects her cheerful excitement. There are two main types of cadenza in the cabaletta 'Ah! non giunge'. One is the legato cadenza, and the other is the staccato cadenza. These two types of cadenza sometimes appear separately and sometimes merge with each other. When we sing a legato cadenza, it is important to ensure that the focus of the breath is always on the diaphragm. However, I have also found that when I sing a staccato cadenza, the vocal cords need to quickly engage and disengage (independent of breathing), and I also have to pay more attention to the flexibility of sound, while maintaining accurate intonation. ${ }^{48}$ For example, in the singing of the last cadenza, not

\footnotetext{
47 The figure is taken from https://kupdf.net/download/bellini-an-non-credea-la-sonnambula_5af9b106e2b6f53e7fee1be7_pdf. All the other figures for this song are from the same edition.

48 Richard Miller, Training soprano voices, Oxford University Press, USA, 2000, 47.
} 
only does the singer need to maintain the consistency of the sound, but also every tone must be sung clearly and accurately.
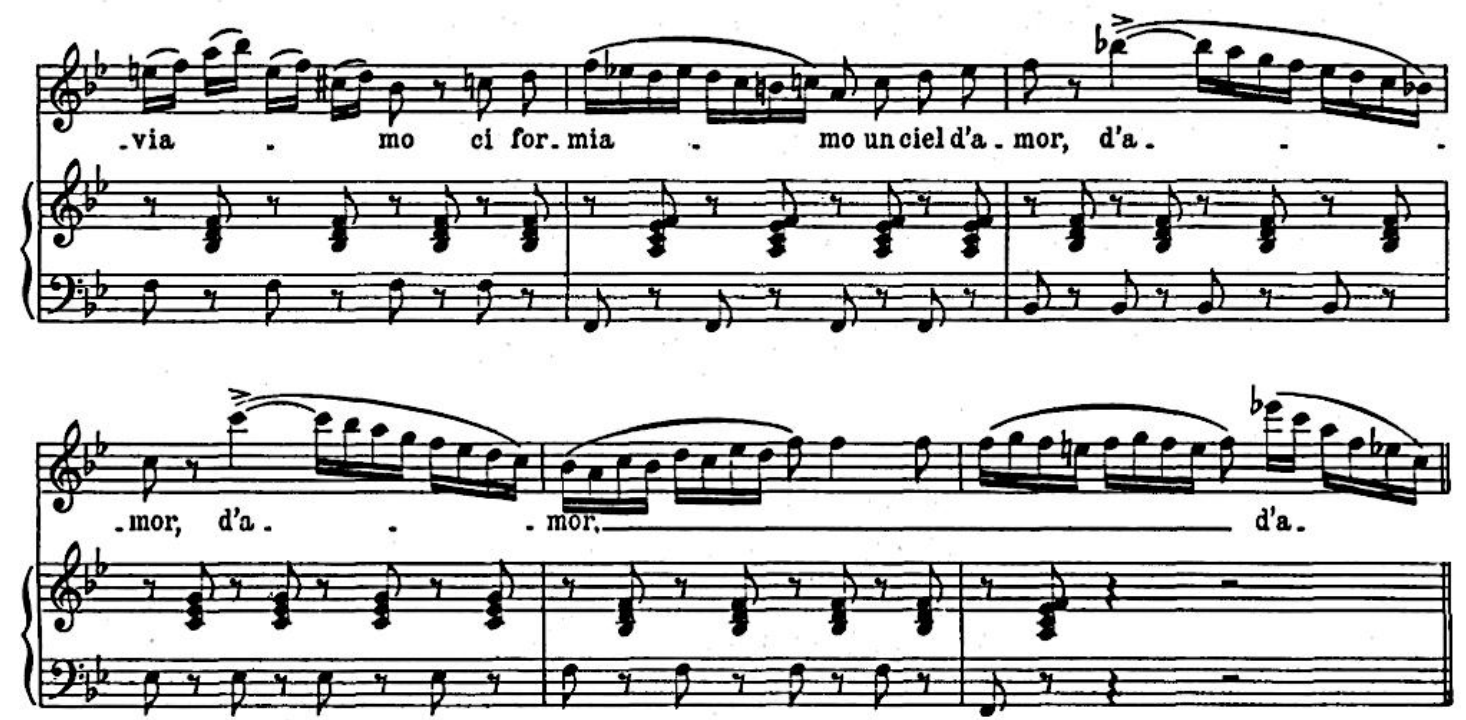

Figure 10. Fragment of 'Ah, non giunge’ (Bars 69-74)

At the same time, when singing the staccato cadenza, we still need to sing each staccato with the support of the breath. After learning the melody, we can practice the cadenza by starting it on a lower pitch and gradually reaching the original pitch through a series of progressive half-step tones. ${ }^{49}$ At the beginning of the practice, it is necessary to try to slow down and sing every interval accurately, and then gradually increase the speed. However, we should always maintain the flow of breath and the flexibility of the sound, until finally we can freely follow Bellini's requirements of tempo and dynamics to sing.

\section{The Application of Tone Colour}

Caroline Abbate suggests that when male and female singers perform on stage together, the singing of female characters resonates more and attracts the attention of the audience more easily. She states: 'Visually, the character singing is the passive object of our gaze. But, aurally, she is resonant; her musical speech drowns out

\footnotetext{
49 Richard Miller, Training Soprano Voices, 64.
} 
everything in range, and we sit as passive objects, battered by that voice.' Abbate proposes moreover that female voices therefore slide into the "male/active/subject" position and take away the voices of creation from the composers. ${ }^{50}$ Moreover, I suggest that this may be to do with the sensitive and passionate characters women portray, so the heroine in the opera is often more complex and personalized than the male character. From learning and singing this particular aria, I have found how important it is for female singers to be sympathetic to the characters they are performing.

In opera performances, singers mainly use voice to shape characters, so this requires female singers to use their tonal changes to reflect the details of the personality of the characters. This is like an embodiment relation between the performer and the tone technique. This relationship means the performer and the tonal technique must be fully integrated. In the case of good use of tones, the singer does not use her sense to directly convey the emotion of the character, but uses the change of the tone to make the audience perceive the inner world of the character. Generally, a bright and full tone represents happiness and joy; a dark and withheld tone represents sadness and sorrow; when the character is angry, the tone is rough and harsh; and when the character is nervous, the tone is sharp and dry. ${ }^{51}$ Although the soprano's age may be different from the actual role, they can choose an appropriate timbre according to the different emotions and characters in the music when singing as well as choosing one that gives the sense of the age of the character.

In the opera La Sonnambula, Amina is a pure and kind young girl. Therefore, we should try to keep the sound clear and flexible when we sing, and change the tone

\footnotetext{
${ }^{50}$ Carolyn Abbate, "Opera; or, the Envoicing of Women," Musicology and difference: gender and sexuality in music scholarship (1993): 254.

${ }^{51}$ Katja N. Goydke, Eckart Altenmüller, Jürn Möller and Thomas F. Münte, "Changes in emotional tone and instrumental timbre are reflected by the mismatch negativity," Cognitive Brain Research 21, no. 3 (2004): 351-359.
} 
according to the varieties in the mood of the character. A clear voice means that there is no impurity, so in a sense it is a manifestation of purity. In addition, this tone also represents the character of a vibrant young girl. For example, when singing 'Ah! non giunge', considering that Amina is feeling an extreme happiness at this time, a bright tone can be used to express her mood. This piece of music is full of staccato passages as well, which help to convey Amina's excitement. Therefore, the singer needs to keep the sound bright while maintaining the elasticity and lightness of the sound, so that the character can be vividly displayed in front of the audience. Moreover, the difference is that when 'Ah, non credea mirarti' is sung before 'Ah! non giunge', although the same clear and flexible voice is also required for the first aria, the mood of the character is sorrowful at this time. Therefore, we can make a sound similar to the sob state, making the sound slightly rich and not too bright, so that we can express Amina's sad mood. ${ }^{52}$ The tone at this time really plays a role in accentuating the character and expressing the character's emotions.

\section{Expression of Emotion}

Opera is not a single song. It is a stage work with stories, plots, and content. Therefore, performers need more than just proficient singing skills, they also need to understand and express these aspects of the opera. Nowadays, sleepwalking is familiar to most people, so there is no novelty in this, and what audiences may value in this work is the way the singers express the character's emotions and act this role. In 'Ah, non credea mirarti... Ah! non giunge', Amina's mood has changed a great deal. She is dominated by two emotions: extreme sadness and extreme happiness, which portray her as a pure and kind image.

\footnotetext{
52 The 'sob' quality in singing is a soft and dark voice, which is related to the sob crying of mourning adults. A lowered larynx and thinned vocal folds will produce sob quality. The quality of the sob will release glottal hyperadduction and medial compression, lower the larynx and release pharyngeal constriction. (The source is from Tom Harris and David Martin Howard, eds, The voice clinic handbook, Compton Publishing Limited, 2018, 232.) 
In the plot of the opera, at the time of 'Ah, non credea mirarti' Amina is not only heartbroken, but also desperate, and her spirit is on the verge of collapse. Therefore, the performer should distinguish this degree of sadness from the sadness Amina experiences in the earlier stages of the opera, and sing this piece more desperately but in a way that makes sense for the sleepwalking. ${ }^{53}$ What is more, because this aria is sung while Amina is sleepwalking, so although it is sad and even sounds depressed, it should be internalised rather than the sadness being physically visible through sobbing or wailing. The dynamic does not need to be too large either since she is sleepwalking.

The following cabaletta, 'Ah! non giunge', which occurs on Amina's awakening from sleepwalking, is filled with happy emotions as she is shocked and happy in the face of the lost love that has been returned to her. This kind of happiness is not expected but a surprise, so we can show a sudden change to happiness. Also, unexpected emotions are probably more intense than ones when we have been expecting something to happen - so the singer's expression of these can be as heightened, stronger emotions. Moreover, Amina is an unmarried young girl. She is happy for her love, but at the same time, the singer needs to show that she is immature and somewhat shy.

\section{Performing Young Roles}

Although Bellini set the age of Amina to be younger than my actual age, in addition to changing the tone or deeply understanding the character's emotions, I have found that the most important thing is to put the character into my heart. As Judith Butler demonstrates, gender and sex are performative characters. This theory can be especially applied to vocal performances, since songs are performed by voices and voices emanate from bodies. ${ }^{54}$ For example, when I sing this song, I need to imagine

\footnotetext{
${ }^{53}$ In the previous plot, Amina sleepwalks into the Count Rodolfo's room and sleeps in his bed, causing Elvino to misunderstand and cancel the wedding. At that time, Amina feels more grief and even faint.

${ }^{54}$ Elaine Barkin, and Lydia Hamessley, eds. Audible traces: Gender, identity, and music, Theodore Front Music, 1999, 25-26.
} 
that this teenage girl who is unmarried and full of longing for and cherishing love is me. Although I am a virgin suffering for love in an ordinary village in the nineteenth century, I will embed this thought in my twenty-first century body.

In addition, before I learn to perform this role, I first need to clarify my responsibilities. As a singer performing on stage, I need to shape the characters and show the plot, and show it in front of the audience through my performance skills. Therefore, the performer should first be familiar with the role. 'Familiarity' here is not just to learn songs, but to understand the personalities of the characters and the ins and outs of the plot. For example, what Amina should look like when she starts sleepwalking; What she is thinking when she and her lover resolve their misunderstanding and so on.

After getting familiar with the music and the character, the next step is to decide what skills to use to shape this image based on the understanding of Amina. Here, I am a performer in my twenties and I am going to perform the role in my early tens young girl. The girl's voice, posture, action and expressions do not appear for no reason: there should be causes and consequences for these. I have already discussed the change of tone above. In addition, the overall appearance of the performer also needs to change. Therefore, I need to observe the behaviour of young girls, especially those in love. Although I have experienced this state, it is not what I am now. In my recital, I am still singing as a young nun who is spiritually uplifted in the previous song before this aria. However, when this aria starts, I need to adjust immediately to a state of sadness. Since I am sleepwalking, I also need to try to gain a sense of the feeling of unconsciousness. Since I will sing the two arias in succession, and there is no stage action in between them, after singing 'Ah! Non credea mirarti', I need to quickly adjust my state to the situation where my sad feelings are lost and I recover, and then come to sing 'Ah, non giunge'. At this time, my expression can be very happy and 
excited. When I am singing, in addition to the clear voice representing the younger character, the placement of voice can be moved forward, making the tone brighter to represent Amina's cheerful emotions. The corners of my mouth can be curved up, and my hands can be held in an expressive position so that I can show the joy again, or even fear of losing his love again.

In operatic works, it is not uncommon for women to be loyal to love and hurt by love. In La Sonnambula, Bellini's dramatic image of Amina that is appearing in front of audience in this aria is a pure country girl with no shortcomings. She is pure, kind, gentle and considerate, who gives everything to love.

The three songs in this chapter are filled with a sad atmosphere, but the three heroines in the works are experiencing different painful situations. The young nun is suffering from an earlier love affair, so she wants to escape reality and decide to show her devout love to God for salvation and liberation. Giulietta is forced to marry someone she does not love, but under the constraints of this feudal system, Giulietta is still firm in her love, yet this 'firmness' brings sorrow to Giulietta's image. Amina's sad song happens when she is sleepwalking. She simply does not know what to do to relieve her lover's misunderstanding of herself, and she seems confused and helpless.

\section{Summary - The musical shaping of the maiden's sighs}

In this chapter, the 'Die junge Nonne' is slightly different from the other two arias in shaping the character. Firstly, the piano accompaniment contributes directly to the atmosphere in this song. For example, the piano accompaniment sets up the mood of a dark night with thunderstorms, and the same note being repeated at the end of the song imitates the bell that is about to start the wedding ceremony. In the two Bellini arias, while the orchestral accompaniment also contributes to the atmosphere, the 
singer retains more freedom of expression through cadenzas and melodic themes that are arguably less integrated with the accompaniment. The singer shapes the musical colors, and changes the tone (interrogation/helplessness/grievance, etc.) of the heroine more independently from the orchestral accompaniment. Secondly, in singing, 'Die junge Nonne' emphasises the harmony of vocals and piano. The other two arias require more vocal skills to show the character's psychological changes. The relatively free tempo of certain phrases also gives the singer some more opportunities to perform with a variety of tonal shading, and expressive phrasing. 


\section{Chapter Three - Passionate Love: Lento foco - the burning heart}

\section{'Gretchen am Spinnrade' by Franz Schubert}

The song was created on 19 October 1814, when Schubert was only seventeen years old. In 1814, the 17-year-old Schubert wrote the song based on a poem within of Goethe's play 'Faust'. This song reflects the perfect combination of poetry and music, and focusing on the fit of text and melody. The music lines between the words are full of poetic and artistic meaning. This is the song of Gretchen, who is sitting alone and soliloquizing at her spinning wheel. This song breaks the previous concept that vocal melody should be the main focus of a song, and entirely integrates the connotations of the lyrics and the specific implication of the accompaniment. Through the integration of these two aspects, the singer's inner world is re-created musically and we are shown the emotions that the girl experiences as she is obsessed with Faust and the excitement after the first intimate contact with her lover as well. ${ }^{55}$

The whole song is in ternary form. In addition, each part of the melody consists of three sections, and each section includes three sentences. The first section of each part has the same text, which is equivalent to the 'refrain' in strophic form. The piano accompaniment plays a spiral-shaped fast pattern from beginning to end, depicting the wheel which keeps turning on the spinning wheel. Therefore, such vivid accompaniment allows the singer and accompanist to be inseparable.

\section{Piano Accompaniment to Shape the Images of Music}

In the prelude of the two bars, the right-hand part of the accompaniment is a symbol of the spinning wheel. The left hand part is a simple form with D minor chords, where the tones are soft and staccato as if Gretchen is muttering. The piano has risen from

${ }^{55}$ A. Craig Bell, The Songs of Schubert, Lowestoft: Alston Books, 1964, 16-17. 
only accompaniment to a position as prominent as the voice. In addition to making the whole music appear layered, Schubert's imitation of the spinning wheel in the piano part gives the audience a dramatic sense of reality, as if there is really a beautiful girl who is singing while spinning the thread.

Through these musical effects the opening portrays a feeling that, because she has just tasted love for the first time, Gretchen's emotion moves excitedly. Before singing, the singer's heart can imagine: a young girl who is sitting next to a spinning wheel, she is agitated and lonely thinking about her lover, as well as falling into an unpredictable love illusion. However, these illusions can only bring her more crazy enthusiasm and obsession with love.

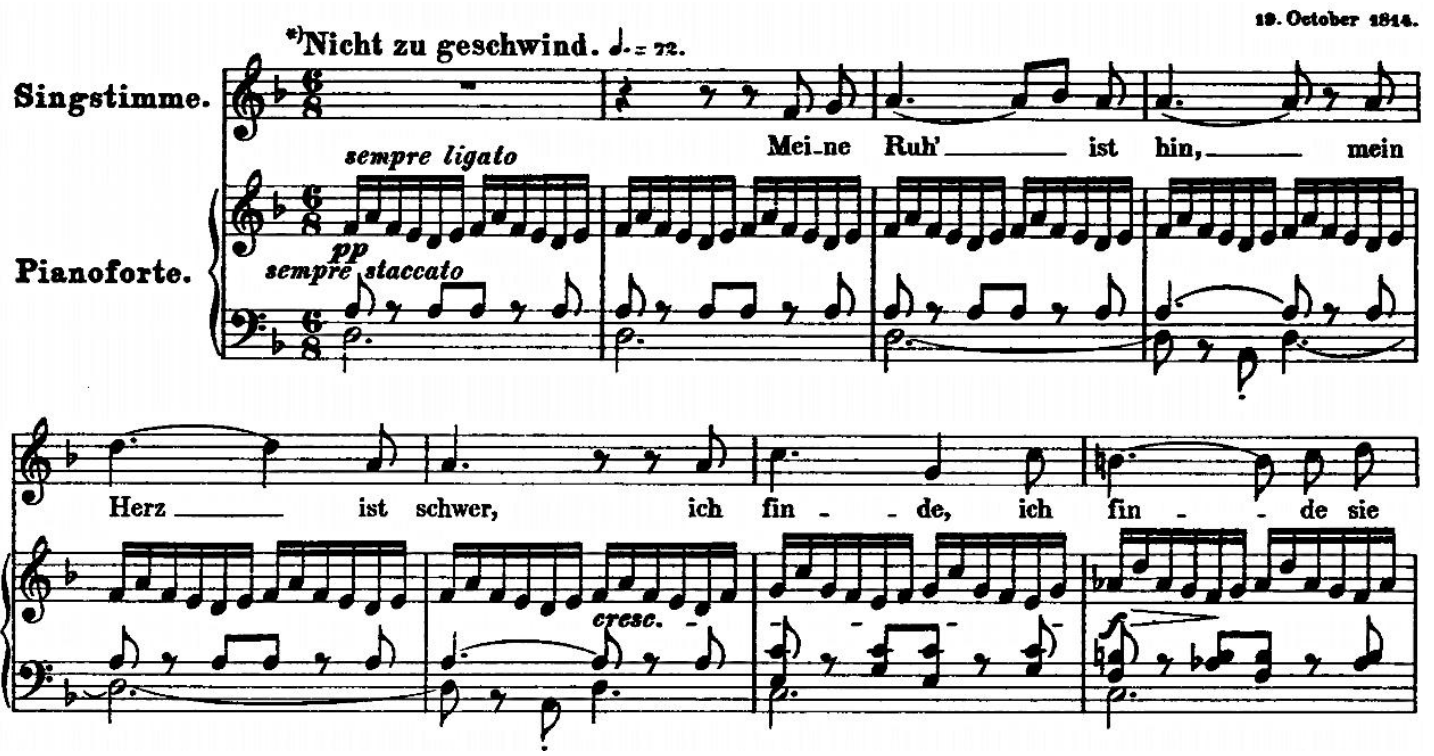

Figure 1. Fragment of 'Gretchen am Spinnrade' (Bars 1-8) ${ }^{56}$

While 'meine Ruh ist hin' is only marked with a pianissimo in the accompaniment, the character's emotion is intense, so the singer needs to sing with a sense of excitement. In bars 7-11: 'ich finde ich finde sie nimmer und nimmer und nimmermehr', the voice line is legato, but the running of the fast scale in the

\footnotetext{
56 The figure is taken from

https://imslp.simssa.ca/files/imglnks/usimg/c/ce/IMSLP13971-SchubertD118_Gretchen_Am_Spinnrade.pdf. All the other figures for this song are from the same edition.
} 
accompaniment part means that under the calm appearance of Gretchen, her heart has been swayed by love.

\section{Tonal Color changes Character Emotions}

Moving on to the second part, bars 31-40 repeat the opening section. Here, the singer can sing a little differently from the first time, expressing here the rich emotional change of the heroine's heart at this time. After that, Gretchen shows her fascination with Faust - she is only attracted by him. The emotional colour changes through a key change to F major at bar 51. After bar 55, the melody is marked with crescendo and and accelerando (increasing volume and speed), and the chords are always inverted. At this time, Gretchen thinks of Faust: 'his superior way of walking, his noble figure, his smile, his eyes' power, his enchanting flow of speech, the clasp of his hand and his kiss!' The singer's breath is smoother than before, and the tone can be adjusted to be slightly brighter. In this part, Gretchen is getting more and more excited until the climax is reached at bar 68 . In bars $66-68$, the motive for the rotation of the spinning wheel is stopped, because the young girl, has completely sunk into the sweet world of fantasy, and forgets everything else so she stops pushing the pedal of the spinning wheel. It expresses her longing for close contact with Faust. The fermata of the bar 68 is very important, and the melody returns to D minor, as the girl's fantasies are shattered and she returns to reality.

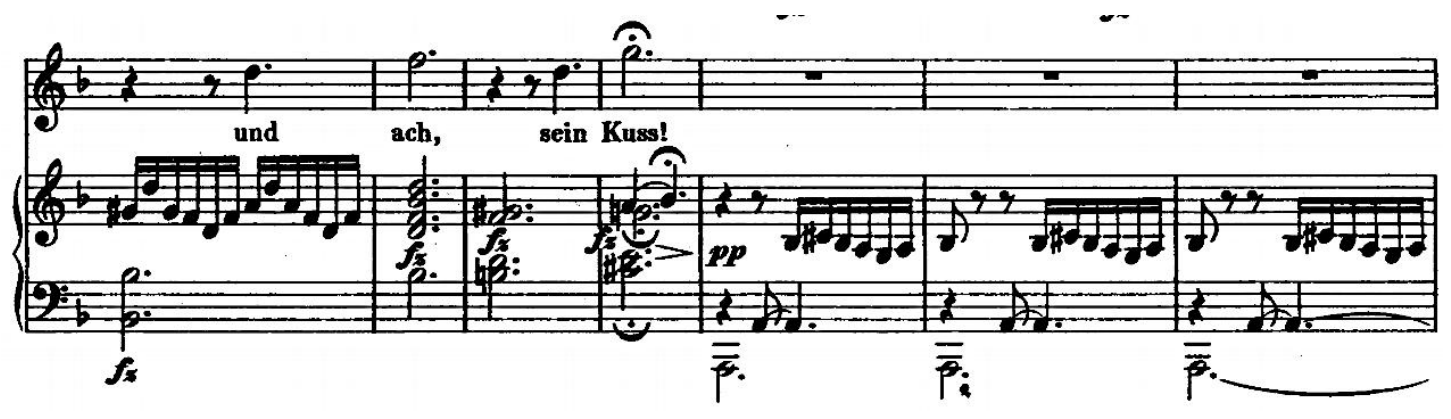

Figure 2. Fragment of 'Gretchen am Spinnrade' (Bars 65-71)

\section{Use of Singing Skills}


The left-hand motif (the low note followed by the octave above it) is like the girl stepping on the pedal of the spinning wheel. The spinning wheel turns and stops again. It represents the girl's return from fantasy to the real world. She is unable to immediately recover from her fantasy, so Schubert arranges a good interlude in the bar 73-82, in which the melody is the same as the first part. However, when they start singing again, performers can sing differently than before. It shows that although the girl returns to reality, she still remembers the crazy fascination with her lover Faust. In bar 85 speed begins to increase gradually, until the highest tide (bar 107 and bar 111), and then gradually slows down. Schubert gradually pushes Gretchen's emotions to a peak by using layers of advancement. When this last dramatic conflict reaches its apex, at the moment when Gretchen's feelings break out $\left(\mathrm{d}^{2}-\mathrm{a}^{2}\right)$ in bar 106-111, and the singer can sing with the support of breath. Although the ascending scale generally shows external painful emotions in the minor, here it is combined with a pure fifth interval with neutral feelings. It expresses Gretchen's hunch about the imminent tragedy, so the dynamic of singing can be properly controlled.

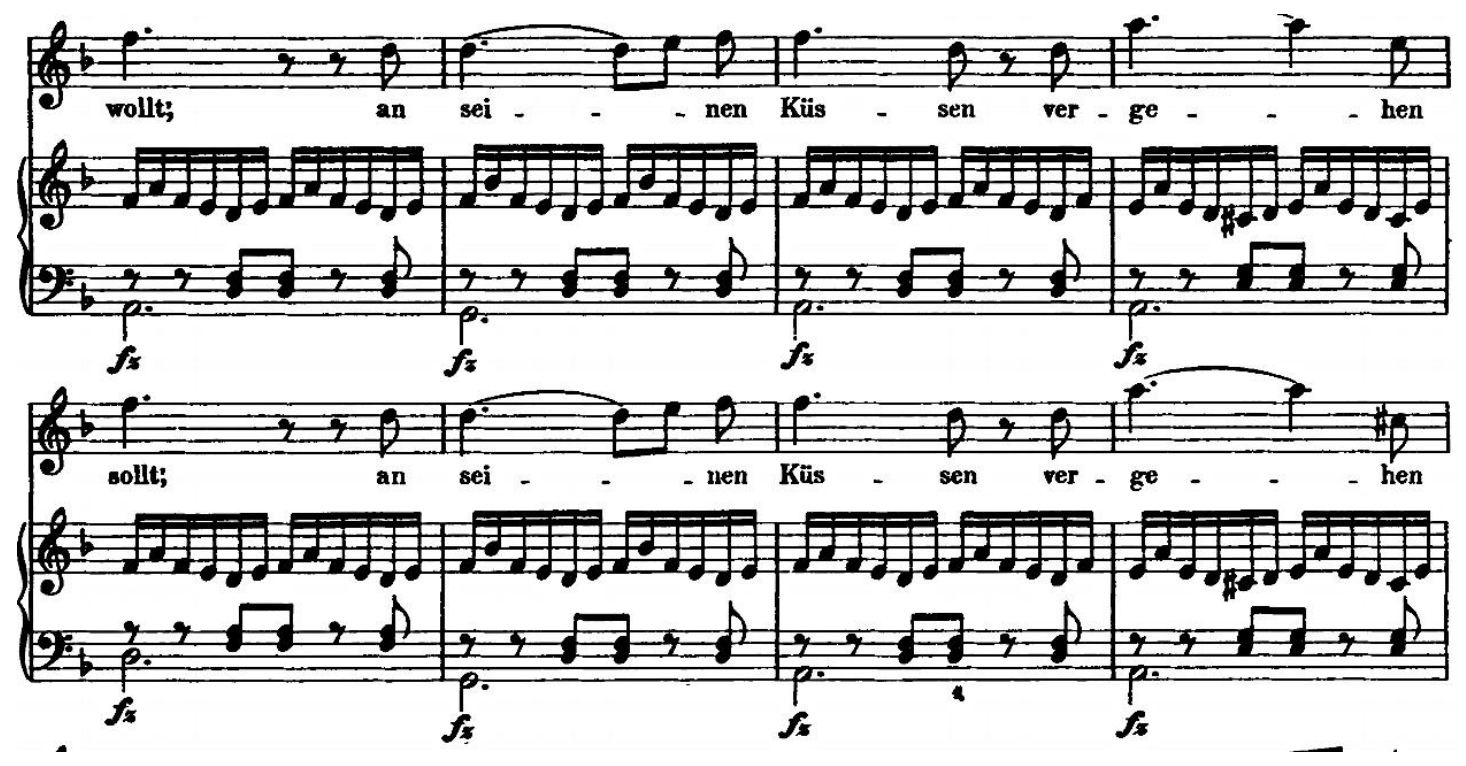

Figure 3. Fragment of 'Gretchen am Spinnrade' (Bars 104-111)

The ending sentence 'Meine Ruh ist hin, mein Herz ist schwer' means 'I have lost my peace, I have a troubled heart!' The young girl can no longer bear everything, pushing 
her emotions and even the sexual fantasies to a high tide. After that, returning to the main melody, the singer can sing the last sentence with a repressed mood as if it is unbearable. When the last sentence is finished, Gretchen is exhausted, and the spinning wheel is slowing down as well as getting weaker. Finally, the spinning wheel stops powerlessly.
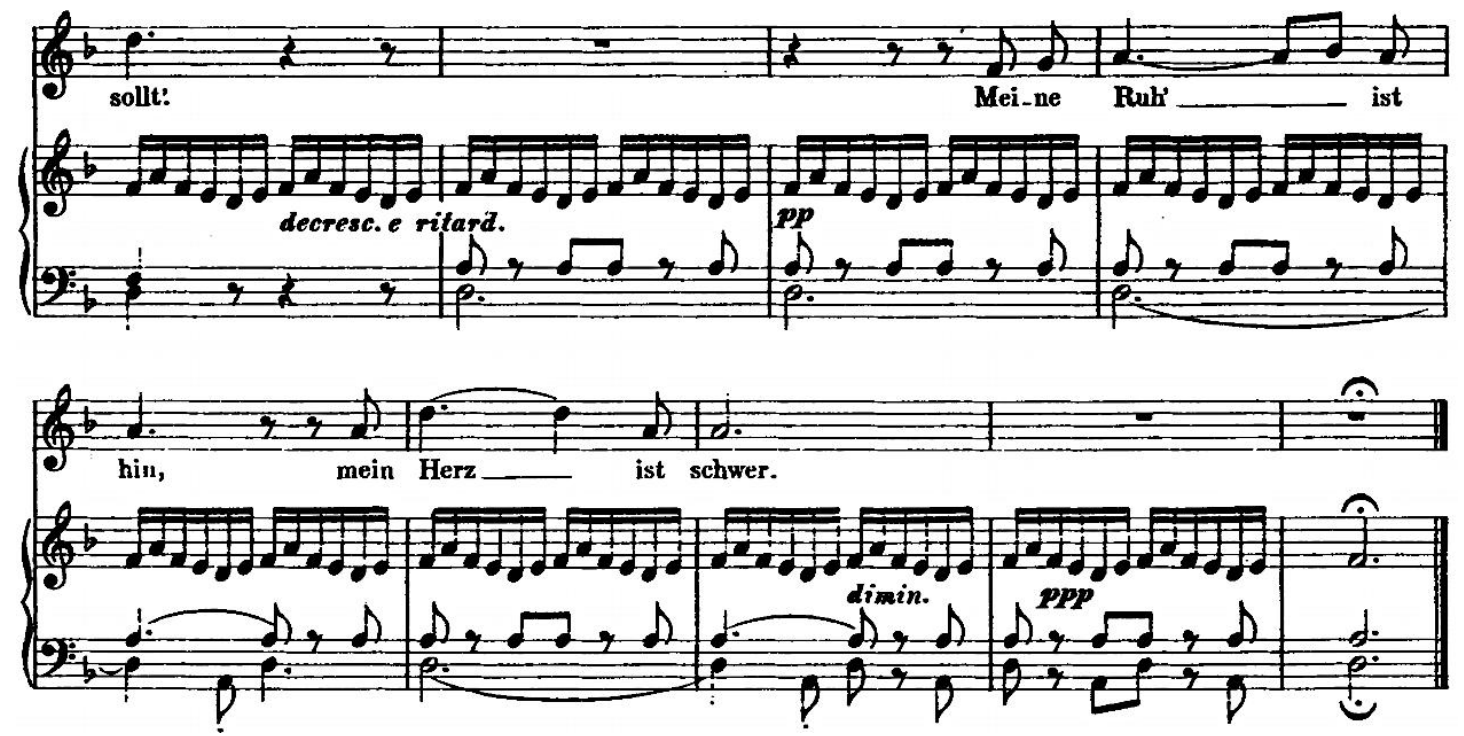

Figure 4. Fragment of 'Gretchen am Spinnrade' (Bars 112-120)

\section{Preparing and Performing 'Roles' in Lieder}

When singing this song, in addition to the style that German and Austrian art songs should have, performers should also be aware of the tragic heroine of 'Gretchen'. This means that female singers need to find out the background of the poetry to fully understand the character of Gretchen during the singing of lieder, and then find a way to empathise with it in order to sing this role. This is similar to the process I mentioned earlier for preparing to perform characters in opera. However, a lied is not fully like an aria. There are often several plots which affect the opera arias. We can understand the ins and outs of this character after studying the full opera. It is possible that the female characters in lieder exist independently in this song, or even use other objects as metaphors for female images. Therefore, it is important to start with the text of the poetry to analyze the character and her emotional changes. 
The story of 'Gretchen am Spinnrade' takes place in the theme of the pursuit of love, which underpins scene 7 to 24 in the first part of Faust. The first part of Faust covers the 'Gretchen tragedy' from scene 7. Among them, in scenes 7-13, it expresses Faust and Gretchen's love process. Goethe describes Gretchen's life and fate, and he portrays her distinctive personality. The specific plot is: in front of the church, Faust meets the beautiful girl Gretchen and immediately falls in love with her. With the help of the devil, he quickly gets Gretchen's love. In order to enjoy the joys of lovemaking with Faust, Gretchen then uses the sleeping pills given to her by Faust to make her mother sleep. Unexpectedly, because of the excessive dose, she poisons her mother. Faust also kills Gretchen's brother because he tries to stop him' from being with Gretchen. After all of these things Faust leaves and Gretchen is distraught and goes mad. She unconsciously drowns her and Faust's child, and she ends up in prison. Faust comes back eventually, and tries to break into the jail and rescue Gretchen, but Gretchen refuses to go with him, recognising the devil at his side. ${ }^{57}$

For me, this story is also the most dramatic one of the Faust story. The sweet love shown in scenes 7 to 13 is in stark contrast to the desolate misery of scenes 18 to 24 when Gretchen is in prison. 'Gretchen am Spinnrade' is from scene 15 of the first part. In the scene Gretchen sits alone at the spinning wheel and describes her feelings after falling in love. These feelings about Faust are sincere and violent. The overall tone of emotions continues to move forward.

However, although Gretchen is a young girl with a passion for love, she is also a tragic character. In my opinion this requires that the singer's tone should not be too bright, and the dynamic should be properly controlled. The singer should also use a more concentrated voice to express her passion for her lover. Moreover, performers

\footnotetext{
${ }^{57}$ Rainer Matthia Holm-Hadulla, Goethe's Path to Creativity: A Psycho-Biography of the Eminent Politician, Scientist and Poet, Routledge, 2018, 5-7.
} 
need to have a strong breath control ability to control the sound. When singing this piece, I find that the feeling of triple meters in the rhythm makes the sound flow evenly with the accompaniment texture, like the spinning wheel. When Schubert creates the role of 'Gretchen' by writing music, the melody not only represents excitement, but also represents Gretchen's desire and fascination with Faust, and her sense that they will soon part. Therefore, it cannot be sung with only one emotion and the tone colour needs to change within the song do show this.

Through the development of this melody full of human nature, Schubert reveals Gretchen's desire for love and her desperate fascination with Faust. Schubert's other works will also express this female character of longing, love, and contradictory feelings through songs. He is able to show these female figures to the fullest, also because Schubert lived after the French Revolution and during the Vienna Conference. ${ }^{58}$ At this time, with the improvement of social civilization, society has paid more attention to the status of women, and Schubert, whose status was not of a high class in that society, was perhaps able to relate more easily to the female characters in his creation.

\section{'Quel guardo il cavaliere... So anch'io la virtu magica' (from Gaetano Donizetti's Don Pasquale)}

Donizetti is one of the representative composers in romantic period. He is renowned for his beautiful melodies and coloratura cadenzas. In this opera, which uses a libretto written by Giovanni Ruffini $(1807$ - 1881) and the composer, Norina is a widow who is actually getting ready to marry Ernesto and she is already scheming with Malatesta to fix Don Pasquale's opposition to this marriage. Her trick is to deceive Don Pasquale to sign a marriage agreement with her. Then Norina intends to immediately squander his property and treat him savagely. She also deliberately leaves a love letter

\footnotetext{
58 Duncan Edmondstoune, Schubert, JM Dent \& Sons, 1921, 2.
} 
to make Pasquale suspicious. By the end of opera, Pasquale finds Norina intolerable and tries to catch the man who is dating her. He is surprised to find out that this is his nephew Ernesto. Pasquale decides to accept the facts, and in the end is very happy. ${ }^{59}$

\section{Music Character Creation}

In 'Quel guardo il cavaliere', the aria is divided into two parts. The first part shows the heroine Norina's first appearance. She is reading a romantic novel: Norina is casually flipping through the book in her hand. She is lovingly and comfortably narrating the love story she finds there. The text says:

“Quel guardo,

il cavaliere in mezzo al cor

Piegò i lginocchio e disse :

Son vostro cavalier.

E tanto era in quel guardo

Sapor di paradiso,

Che il cavalier Riccardo,

Tutto d'amor conquiso,

Giurò che ad altra mai,

Non volgeria il pensier."

Ah, ah!

\section{That look}

Transfixed the knight,

he bent the knees and said:

"I am your knight

And in that glance there was

such taste of paradise

that knight, Richard,

completely by-love conquered,

swore that he would never think

of another".

Ah, $A h !$

The original lyrics and English translation of 'Quel guardo il cavaliere' ${ }^{60}$

The opening prelude complements Norina's attitude to this love story through soothing melody and accompaniment, and then presents her lively and lovely

\footnotetext{
59 Gaetano Donizetti, Don Pasquale. O. Ditson, 1888, 5.

${ }^{60}$ Arthur Schoep, and Daniel Harris, Word-by-word Translations of Songs and Arias, Part II: Italian: a Companion to the Singer's Repertoire, Rowman \& Littlefield, 1972, 79.
} 
character through ascending semitones and progressions of staccatos. From bar 11, Norina reads out the love story of the knight and the girl. The accompaniment is using gentle legato phrases to express how romantic is the novel she is reading. Bar 27 is the strongest place in the first part of the emotion, and the ascending scale is mainly used for every phrase in the section. Later, when Norina laughs and expresses disdain for the "love method" in the book, this is underpinned by a progression with the ascending semitones in bar 30. The melody is slow and beautiful, reflecting the softness and singing of the melody, and also vividly showing the lovely and charming musical image of Norina.

In the second part 'so anch'io la virtu magica'. The music style, rhythm, tempo and the shaping of the character's music have changed greatly from the first part. With the burst of laughter from Norina, dotted quavers and acciaccaturas (grace notes) completely change the mood of the music. As the music progresses, the heroine's emotions are rendered and emphasised. Norina throws the book aside disdainfully, and she states her unique views on love. She sings:

So anch'io la virtù magica

D'un guardo a tempo e loco,

So anch'io come si bruciano

I cori a lento foco,

D'un breve sorrisetto

Conosco anch'io l'effetto,

Di menzognera lagrima,

D'un subito languor,

Conosco i mille modi

Dell'amorose frodi,

I vezzi e l'arti facili
I also know the magic virtue

of a look at the right time in the right place,

I also know how hearts burn

on the slow fire

of a brief little smile.

I also know the effect

of a deceitful tear,

of a sudden faintness

I know the thousand ways of

loving deception

the caresses and the skills easy to 
The original lyrics and English translation of 'So anch'io la virtu magica'. ${ }^{61}$

She understands the way men's hearts work, so she can use many different means to conquer men's hearts. The song, with its cheerful allegretto speed and bouncy melody, shows musical images of Noria's enthusiasm and resourcefulness to the audience. Norina constantly emphasises this in the musical climax of the aria:

Ho testa bizzarra,

son pronta vivace,

Brillare mi piace scherzar :

Se monto in furore

Di rado sto al segno,

Ma in riso lo sdegno

fo presto a cangiar,

Ho testa bizzarra,

Ma core eccellente, ah!
I have a whimsical mind,

I have a ready wit,

I like being witty, joking :

If I become angry

I rarely remain that way

But I turn wrath quickly

change indignation into laughter,

I have a whimsical mind,

but a very fine heart, ah!

The original lyrics and English translation of 'So anch'io la virtu magica'. ${ }^{62}$

Through the description of the text, we can feel the changing personalities of the character, and the rhythm is driven forward by the orchestra. Through the advancement of the musical rhythm, the music expresses Norina's passionate and decisive temperament. This allows us to see a resourceful Norina. Through the text and melodic lines, we can feel that this young girl has more confidence and courage

\footnotetext{
${ }^{61}$ Arthur Schoep, and Daniel Harris, Word-by-word Translations of Songs and Arias, Part II: Italian: a Companion to the Singer's Repertoire, Rowman \& Littlefield, 1972, 79-80.

${ }^{62}$ Arthur Schoep, and Daniel Harris, Word-by-word Translations of Songs and Arias, 80.
} 
than the other female images I analyzed before. Norina says that she can easily make a man fall in love with her, showing her high level of self-confidence, and the flirting tricks she mentions also demonstrate that she has the spirit and courage to exert complete control over men, making this musical character quite different from the others I have studied here.

\section{Analysis of Singing Skills}

1) Grace notes

Starting from bar 43 (see Figure 5), a large number of acciaccature and lively dotted quaver rhythms provide a witty and humorous style in the music. When singing this part, because of the rhythm and mood requirements, the singer should pay attention the placement of accents on the grace notes. The previous sound is weakened, making the singing 'bounce'. For example, for 'So anch'io la virtù' the singer should put the accent on 'io' when singing. The 'so anch' at the beginning should be weak, and the voice needs to be crisp and flexible. On this basis, the singer can also maintain the overall coherence of the phrase. This can better mobilise the enthusiasm of the singer, and can fully show the lively, cute, smart and intelligent character of Norina.

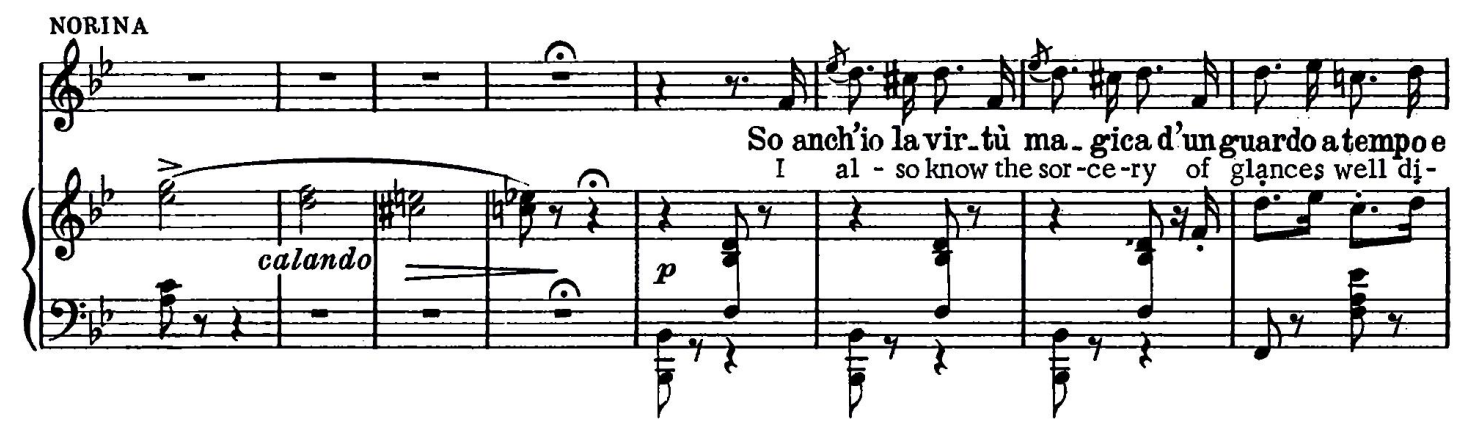

Figure 5. Fragment of 'So anch'io la virtù magica' (Bars 39-46) ${ }^{63}$

\section{2) Trill and Vibrato}

When I sing a trill, the tremor of my singing voice is more obvious, and in order to express drama emotion through trill, the singing duration is usually longer than the

\footnotetext{
${ }^{63}$ The figure is taken from https://kupdf.net/download/quel-guardo-il-cavaliere_59aad01fdc0d60a111568edc_pdf.
} All the other figures for this song are from the same edition. 
duration of the score. From the perspective of acoustics and dynamics, it can be seen that vibrato can resonate through contact with air, so it can make the work more penetrating and infectious, enriching the level of phrases, and making the music more vivid overall. ${ }^{64}$

Trill is one of the basic skills of coloratura. When we sing a trill, we should pay attention to the intensity of the sound. If the singer is too tense, her voice will be stiff and the sound will be harsh. Therefore, it is necessary to control the breathing evenly to control the sound. ${ }^{65}$ In bars 114-120 (see figure 6), the aria uses a long-duration trill to express Norina's inner energy. It's also a very controlled action so it gives us the sense of a lot of energy that is completely under the singer's control (like the power she is describing in the aria). During the singing, the singer is required to immediately enter the resonance cavity at the beginning of the sound position, and use the breath to expand the vibrato evenly so it becomes a trill, and keep it stable at the resonance position.
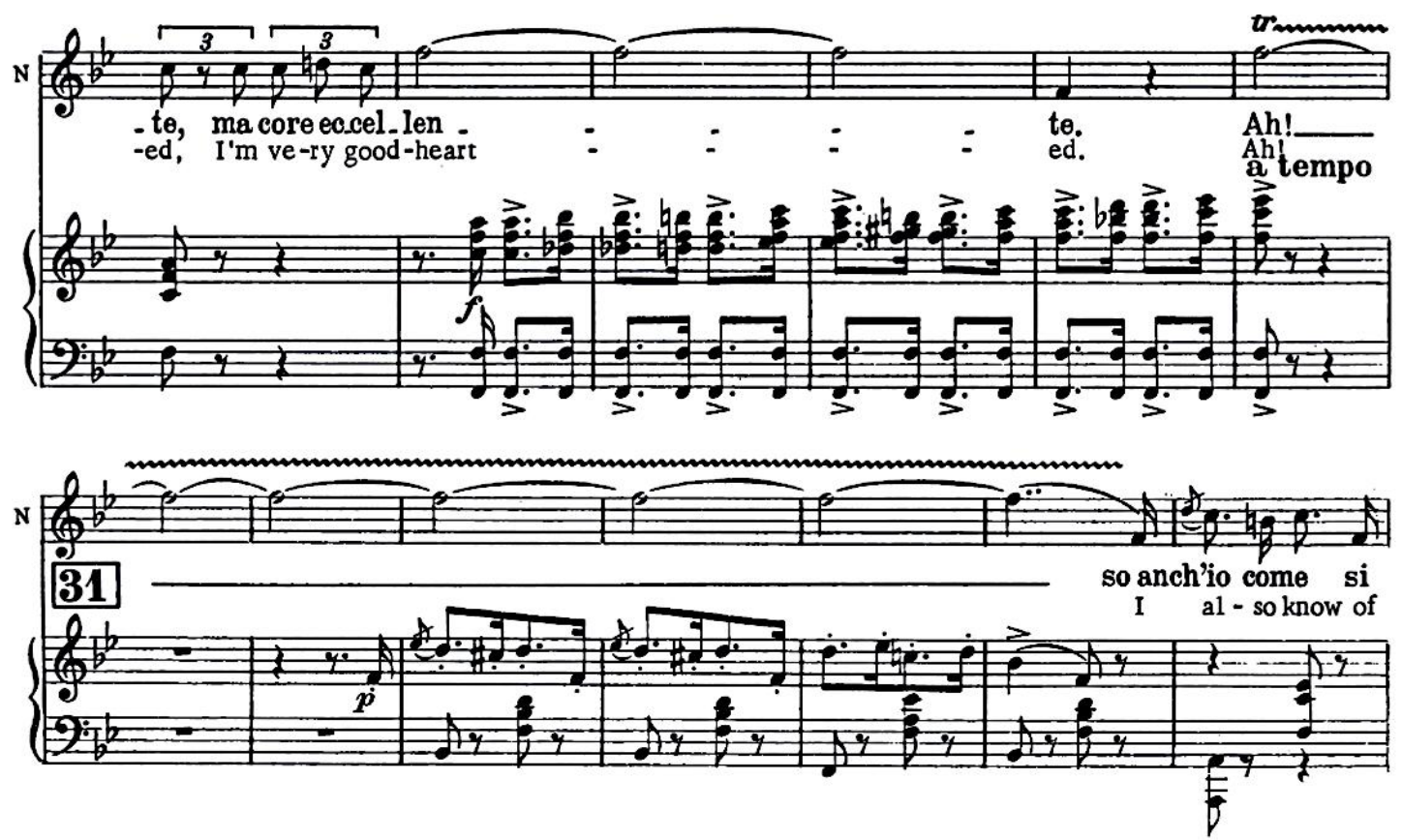

\footnotetext{
${ }^{64}$ Frederick Kent Gable, "Some observations concerning baroque and modern vibrato," Performance Practice Review 5, no. 1 (1992): 9.

${ }^{65}$ Giovanni Battista Lamperti, The Technics of Bel Canto (1905), Gregory Blankenbehler, 2009, 3-4. 
Figure 6. Fragment of 'So anch'io la virtù magica' (Bars 109-121)

\section{3) Rapid Scale}

The technique of rapid scale singing originated from the coloratura favoured by castrato singers. ${ }^{66}$ Later, as women gradually stepped onto the opera stage, soprano singers ushered in a brilliant era of singing. ${ }^{67}$ The fast scale mode of singing emphasises the continuity of breathing. The sound is flexible, smooth and stable, and the sound streams out and flows smoothly. Female singers should explore the most comfortable singing state for producing such scales in daily practice, and maintaining a feeling of blowing bubbles will help make the sound more elastic. We can start with slow practice, sing each note exactly as written, and then gradually increase the tempo.

In bars 168-173, there are 6 bars of continuous ascending and descending scales, and this cadenza pushes the music to a small climax (see Figure 7). The practice of the cadenza should again begin with slow training. First of all, singers should know that when they sing the interval from low to high, the vocal cord gradually changes from shortened to longer. Singers should ensure that their pitch is not too high during the initial singing stage, and then adjust the breath to ensure that each tone can be expressed clearly and smoothly. When I practiced 'Quel guardo il cavaliere' in the early stages, I often felt that the breath I had taken was not enough, and I was unable to maintain the support of the breath until the end of the phrase. In fact, the sound was not flexible enough and the breath was stiff. In order to overcome this problem, we should first sing each note slowly, then we can gradually mobilise the enthusiasm of the body and breathing, and focus on sending the sound forward to make the position of the sound uniform.

\footnotetext{
${ }^{66}$ Matjaž Matošec, "Female Voices in Male Bodies": Castrati, Onnagata, and the Performance of Gender through Ambiguous Bodies and Vocal Act,." Master's thesis, 2008, 43.

67 Susan Rutherford, The prima donna and opera, 1815-1930, Cambridge University Press, 2006, 4.
} 

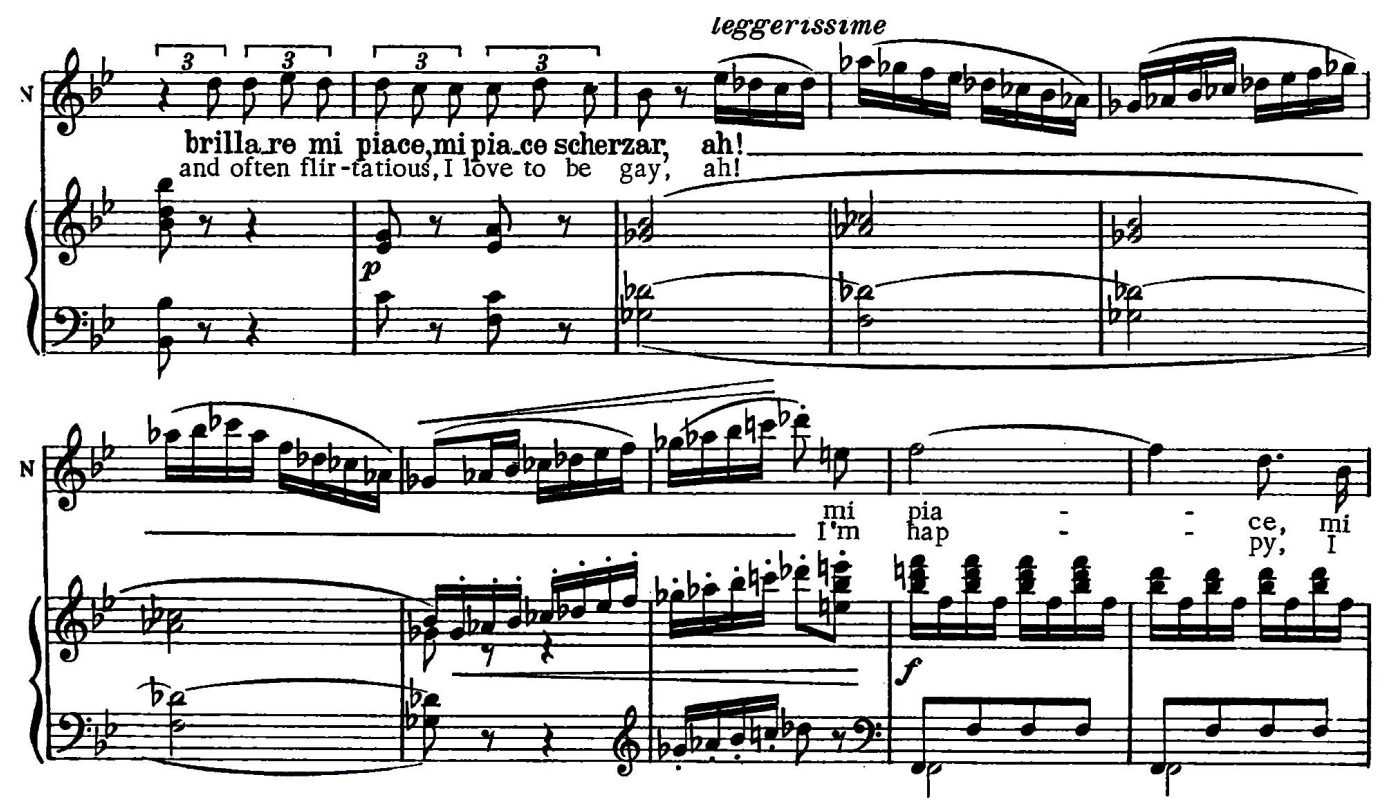

Figure 7. Fragment of 'So anch'io la virtù magica' (Bars 168-181)

\section{Emotional Expression in Singing}

This aria also can be seen from this that the aria plays an extremely important role in the work, and cleverly showing the variability of the character image.

\section{1) 'Quel guardo il cavaliere'}

In the actual performance process, I think there is a significant difference in the emotional expression in the two sections of the aria. The first part of 'Quel guardo il cavaliere' uses a time signature of $6 / 8$, and is in a major position. At the beginning of the music, the range of pitch required is not high, and the sound needs to be smooth and soft. Using a downwards interval of a perfect fifth at the next bar, we can clearly feel the voice change. In addition, with the emphasis on the tone, we can also feel the obvious change in the dynamic of the music, from piano to forte, and then from forte to piano. In this process, I think the emphasis on tone expresses a positive attitude, such as 'Tutto d'amor conquiso' (being conquered by love), here singer should focus on mastering performance skills when singers singing. Not only do singers need to reasonably control their emotions when singing phrases like this, but also make their expressions and movements coordinate when they are acting on stage. 
At the end of the first part, the laughter of Norina which is indicated at bar 30 not only shows her changeable personality characteristics, sometimes lively and cute, and sometimes smart and flirtatious, but also, from way the singer performs the laughter, we can experience the complex and changeable characteristics of the character. If we want to achieve an excellent performance, we should ensure that the singer's voice has a strong appeal and penetrating power, that can affect the audience emotionally. At the same time, we also should pay attention to the use of performance props. For example, when the heroine comes out, she casually holds the book to read. During this section, it is a relatively soothing and quiet atmosphere, but when laughter occurs, we could feel the stage atmosphere changes. The fact that Norina is a widow may influence her attitude to love, and the act of laughing and throwing the book away shows the level of her confidence and open-mindedness.

\section{2) 'So anch'io la virtù magica'}

This part focuses more on the expression of the character's attitudes and her way of looking at life than her emotions, and shows Norina's cleverness, enthusiasm and cheerfulness. When the performer sings the grace notes, it is necessary to pay attention to the tone and appropriately show meaningful emphasis. When singing in a concert situation instead of in a fully staged opera performance, due to the fact there is no staging expected and the movements will be more limited, it is sufficient to ensure natural and smooth movements during the performance, and there is no need to overly exaggerate the performance. The body movement makes the stage performance more affective. For example, the note of 'foco' in bar 51 (see Figure 8) represents affirmative tone, which is to agree with the words of the heroine. 

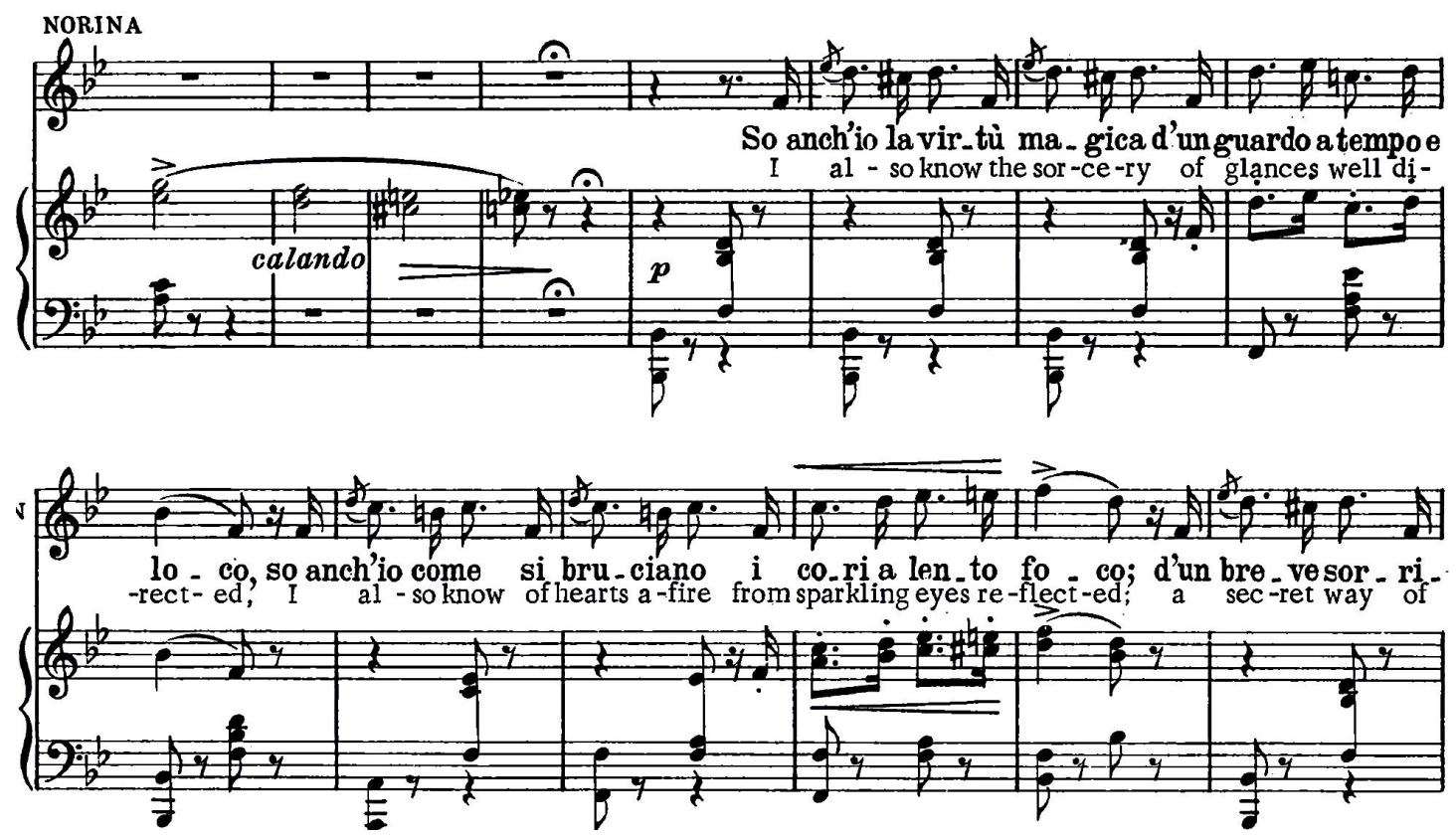

Figure 8. Fragment of 'So anch'io la virtù magica' (Bars 39-52)

In the singing of bar 112 (see Figure 6), the long note 'ah' should be performed with vibrato to give the performance more tension. The entire aria is in line with his standard way of writing arias. He has a precise grasp of the character image, real and vivid, letting people see a lively, lovely, and resourceful female image.

Norina has a variety of amorous feelings and has a wealth of experience to master men. Norina's musical character is also shaped just right to show both female wisdom and a playful image of female youthfulness. Therefore, while she is young, she is also quite different from the young nun, or even the woman in Frauenliebe und leben or Linda in Linda di Chamounix. Norina's behaves most like a modern woman, she has lots of smart and independent signs of modern young girls, and she really goes into action to fight for her love and destiny. In order to be able to get the love she wants, she spends all her thoughts, playing her moves carefully and orchestrating what is in the end a humorous plot. Finally, Norina and her lover achieve their desired result - to be together. 


\section{'Ah! tardai troppo... O luce di quest'anima' (from Gaetano Donizetti's Linda di Chamounix)}

'Ah! tardai troppo' is a coloratura soprano aria from the first act of Linda di Chamounix. This is another example of the genre of 'pastoral' operas that centre around pure virgins and 'simple' country people. ${ }^{68}$ The scene's content is as follows: the protagonist Linda rushes to meeting place set for her date with Carlo, but she finds that her lover has left, he leaving only a bunch of flowers for her. Linda stays here and looks forward to a better future. She sings this aria to express her joy in love. ${ }^{69}$ In addition, this opera is similar with La Sonnambula in that the first act of the opera begins with a setting in the Alps, with the association of metaphors for Linda's purity. Linda's purity is not only a characteristic of the heroine, but an attribute of her family. ${ }^{70}$ This is also the ideology of chastity in the work, and it is also a characteristic feature of society and culture in the nineteenth century. ${ }^{71}$ In this scene, Linda is talking to herself, and telling us how happy she is. Donizetti uses the dexterity of the soprano to express a young girl's inner joy and passion for love. The recitative and aria are Linda's first appearance in the opera, and it is also her only solo piece. Therefore, the aria plays an important role in establishing and portraying the character of Linda for the audience.

\section{Music Style}

This work highlights Donizetti's consistent style and technique of writing, including the characters' very complex emotions. The work reveals Linda's attachment to beautiful love, her longing for love and her deep confession to her sweetheart. The complexity of the character's inner emotional changes also affects the composition of the work, especially where the recapitulation changes the melody at that point, which

\footnotetext{
${ }^{68}$ Gustav Kobbé, and George Henry Hubert Lascelles Harewood, Kobbé's complete opera book, Random House of Canada Ltd, 1987, 382.

${ }^{69}$ Emanuele Senici, Landscape and Gender in Italian Opera: The Alpine Virgin from Bellini to Puccini, New York: Cambridge University Press, 2005, 98-100.

${ }^{70}$ Emanuele Senici, The Alpine Virgin from Bellini to Puccini, 104-105.

71 Emanuele Senici, The Alpine Virgin from Bellini to Puccini, 93.
} 
also serves to show the vocal skills of ornaments, staccatos, appoggiaturas and so on in the soprano's singing. These techniques portray Linda's innocent and lively personality traits, while at the same time enhancing the dramatic contrast of this character in the music.

\section{1) Recitative - Part A}

The music of the recitative ('Ah, tardai troppo') starts with column chords from forte to piano, followed by a series of semiquavers with staccatos. This kind of alternating dynamic shows Linda going to meet her lover Carlo - because she does not see her beloved Carlo, initially she seems a bit lost. This makes the psychological feelings of Linda, who is full of hope and longing for love, a little complicated. In bars 8-12 (see Figure 9), the vocal melody adopts the musical lines of quavers and semiquavers alternately, and the voice range is in the middle range. She is thinking: Why did Carlo miss the appointment, who can ever know how much he has suffered, but now I feel even worse than he must have. At this moment Linda is feeling guilty and is anxious in her heart. She looks for her beloved Carlo. Then in bars 12-15 (see Figure 9), the key changes from $\mathrm{G}$ major to A minor. Linda's mood changes from the bright mood represented by major to the melancholy and dark color of minor. She begins to worry about losing Carlo because of being late. Her beautiful mood suddenly becomes hazy over her face, and she cannot see everything in front of her.

I think Linda is a changeable and moody girl. She can become upset and unhappy even if she is the one who is late. In the twenty-first century, we may think of her as a vulnerable and simple girlfriend. This point, when in the second part she quickly changes so quickly from sadness to happiness, it can also show that she is a character with emotional instability, which comes out more strongly later in the plot. 

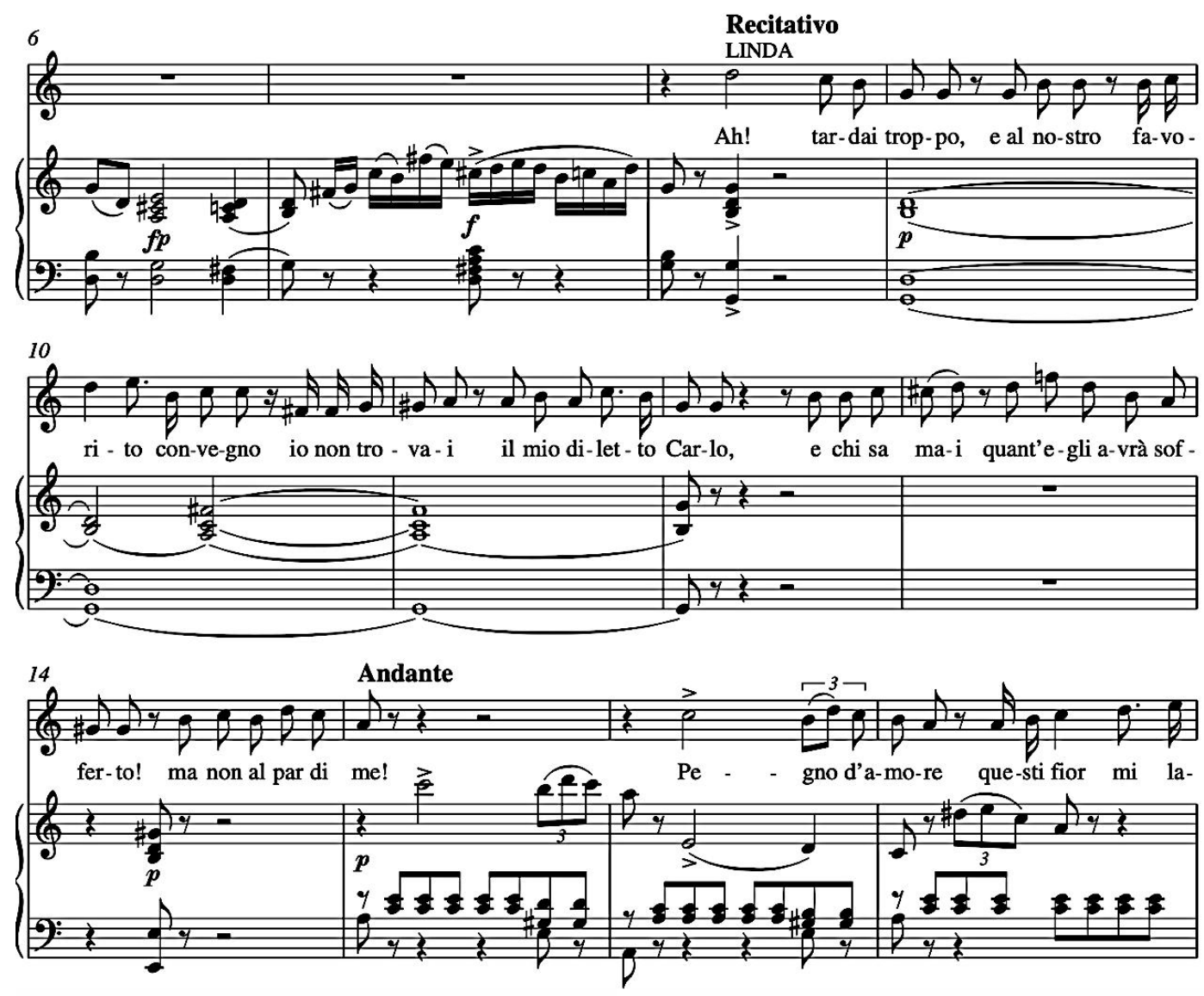

Figure 9. Fragment of 'Ah! tardai troppo' (Bars 6-17) ${ }^{72}$

2) Recitative - Part B

Starting from bar 15, Donizetti uses quaver column chords, and introduces the main melody. The music combines with the text, just like it is expressing Carlo's love for Linda. Linda also sings in the text that although Carlo is a young poor painter, he has a gentle heart and he is full of expectations for life and love. They lean on each other and love each other's hearts. She firmly believes that Carlo will shine through his talent. The tonality switches from A minor to $\mathrm{G}$ major at bar 18 , and the melody includes the leap of an octave. The part adopts the rhythm of quaver triplets, and it seems that Linda can feel Carlo's love for her. She takes the flowers that Carlo has given her and places them on her chest, and the kind of love-filled picture appears before her eyes. The text shows that Linda believes that no matter how difficult the

\footnotetext{
72 The figure is taken from https://www.breitkopf.com/assets/pdf/EB_8867_Oper_Aria_S.-47_48.pdf. The figure
} 10 is from the same edition. 
road ahead is, she will carry her love to the end. In bars 22-30 (see Figure 10), the key changes to $\mathrm{C}$ major again, and the seventh descending progression appears. In bar 29 and 30 (see Figure 10), there are two descending and ascending sequences in the vocal melody, which makes Linda's confused, wandering and feeling of calling for love. Linda is convinced that she will become Carlo's wife. Although she believes them both to be very poor and only able to live on their love of each other, she believes that this is enough. At this time, she has integrated herself into a beautiful scene.

It should be noted that according to the development plot after this aria, Carlo is actually not a poor artist: he is a rich nobleman. However, in this aria, Linda does not know his background. This also shows that this girl is indeed a simple country girl with full of love and trust. She does not ask any questions, nor doubt the answers she received.
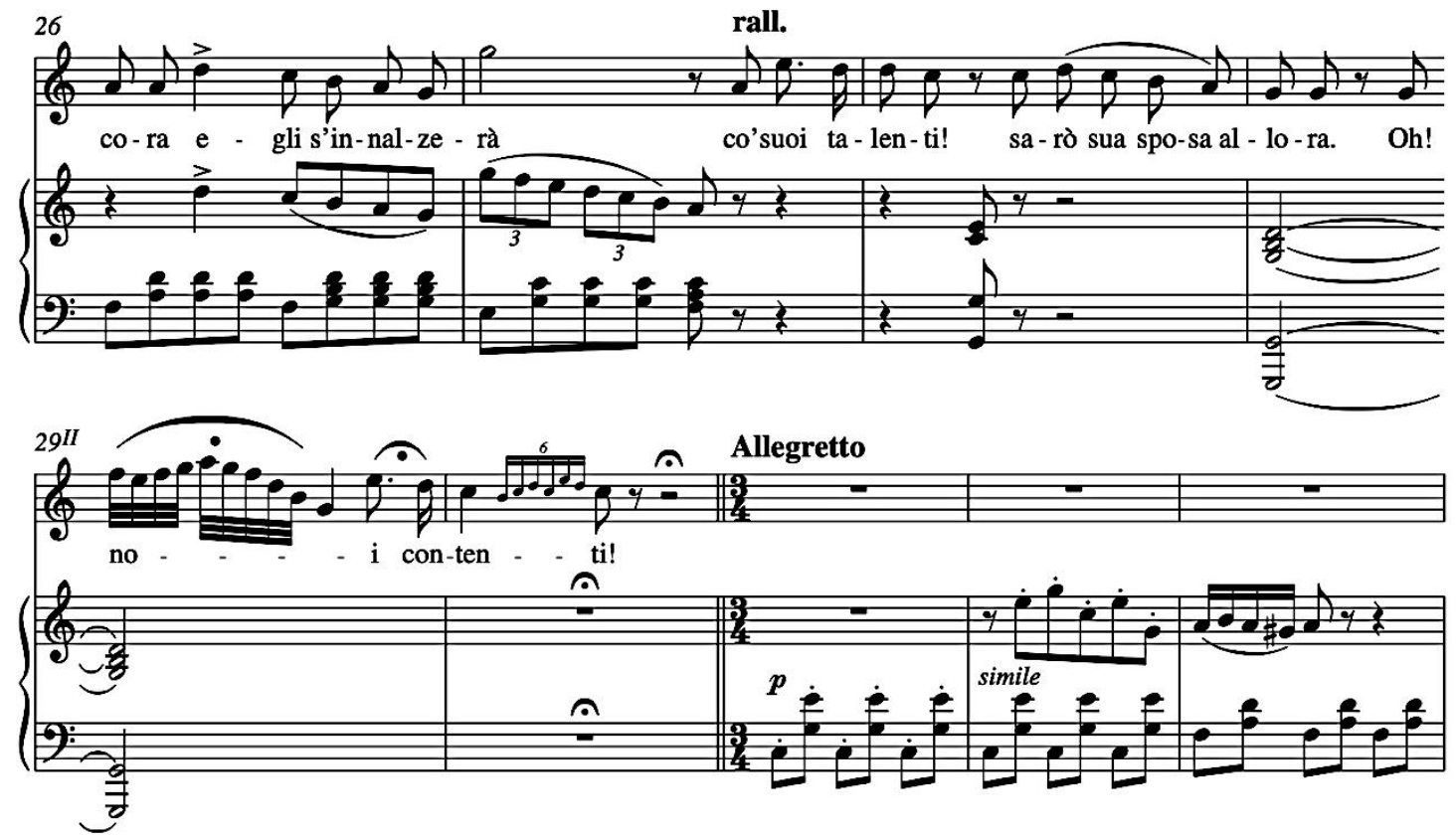

Figure 10. Fragment of 'Ah! tardai troppo’ (Bars 26-33) 
Part A and B are recitative parts. From the above analysis, we can also find the inner thoughts of Linda, from worries about losing Carlo, to the worship of him and the yearning for their future life. This is an image of a young girl falling in love easily.

3) Aria

This aria part is the core part of the whole song. It mainly involves the use of a large number of ornaments and cadenzas in the vocal part. The variety of the theme melody repeats in sequence until the final highest note (high $\mathrm{C}$ ), and finally ends with $\mathrm{C}$ major's perfect cadence. Among them, in bar 74-75 appear a variety of cadenzas. Through the sequences of ascending and descending scales, the music shows Linda's innocent and lively nature, and also reflects the arrival of her beautiful love, which cannot suppress the joy of her heart. Starting from bar 100, the music begins to move towards the coda, and at this point both the vocal part and the accompaniment have repetitions. Eventually the chords progress to the tonic of $\mathrm{C}$ major and finish off the aria. In this way, Donizetti describes the dramatic conflict between the character's inner world and emotional varieties through a series of rhythm, ornamentation and sequence changes. In Linda's heart, Carlo is her life and love. She breaks through the shackles of the world, and she will be with Carlo no matter what, till the end of the world, because she has only Carlo in her heart. This can also be understood from the text of her attachment and desire for love and is demonstrated by her through the heightened excitement of the vocal line as the aria proceeds.

\section{Technical Difficulties in Singing the Aria}

\section{1) Theme Note Pattern}

The theme is composed of partial duration quavers and echo patterns (see Figure 11). For this lively theme, I think that staccato singing can better express Linda's cheerfulness but it should be noted that singing with staccato must not destroy the continuity of the phrase. The meaning of the text in the two bars is implicitly linked, 
so although the staccato notes break up the line, the overall sense needs to be that these two bars form a phrase. It should be sung with the feeling of legato as well. And more importantly, singing with legato also helps the singer to find the rhythm of music. According to the requirements on the score, the accent of this theme should be on the first tone of semiquavers in the following bar, therefore the staccatos of the quavers of the partial duration should be sung lightly in order to highlight the accent.

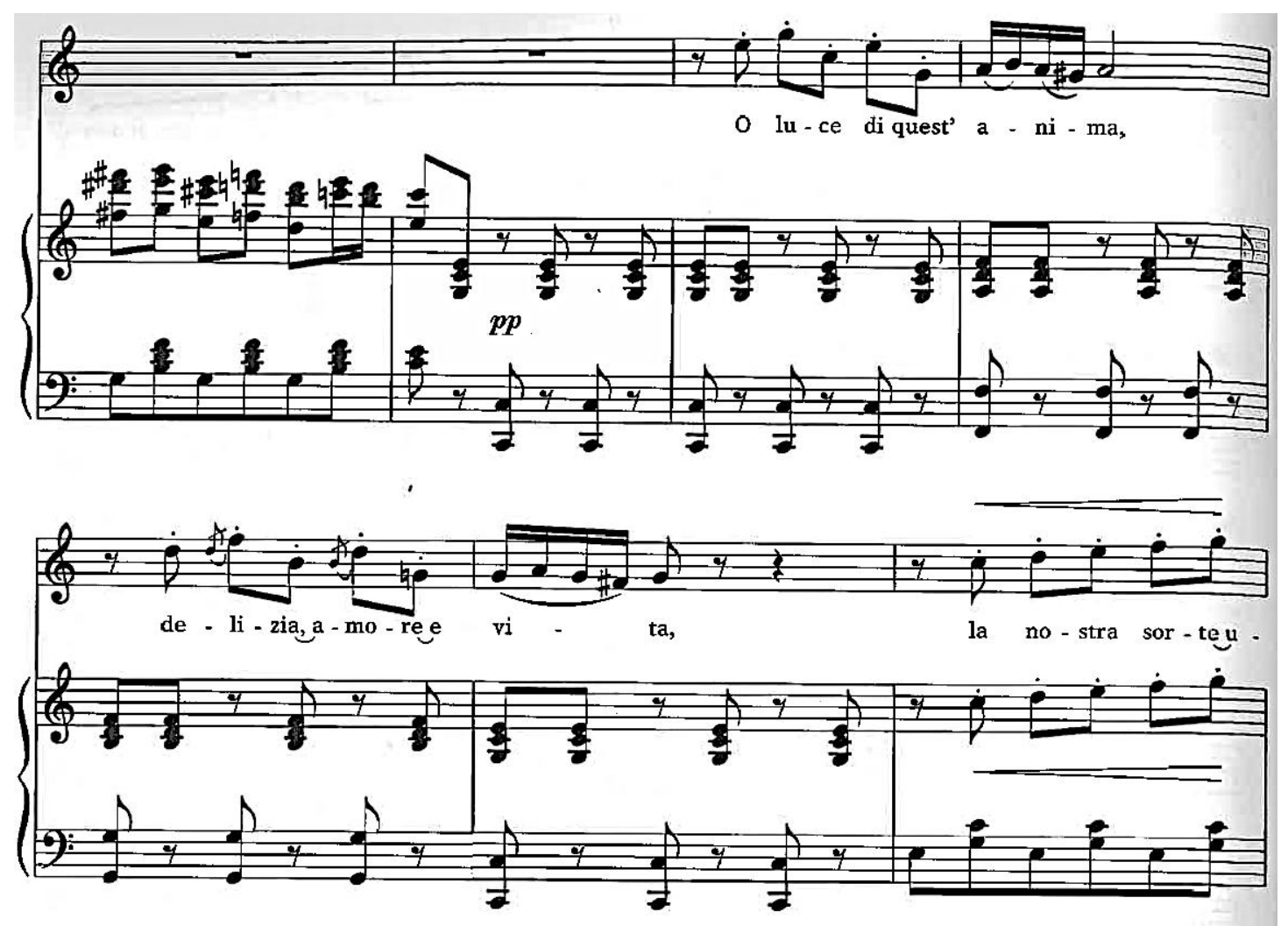

Figure 11. Theme Note Pattern of 'O luce di quest'anima' (Bars 38-44) $)^{73}$

\section{2) Ornaments}

In the following phrases, the composer adds acciaccature to the theme melody (see Figure 11), which makes the vocal effect more lively and dexterous. Such ornaments appear frequently in arias, and the grace notes should occupy little duration of the main notes. Therefore, if singers do not sing them quickly enough, they may sound like portamentos, which will mean the sound will lack clarity, and it will not reflect

\footnotetext{
73 The figure is taken from Robert L. Larsen and Martha. Gerhart, "Coloratura Arias for Soprano" New York, NY: G. Schirmer, 2002, 153-164. All the following figures for this song are from the same edition. 
the instrumental characteristics of the coloratura soprano part. However, if we sing according to the effect of Figure 12, that is, the duration of the ornaments occupy the duration of the previous beat, then the ornaments and the main notes can be clearly presented, which can be more expressive of the joy underlying the music.

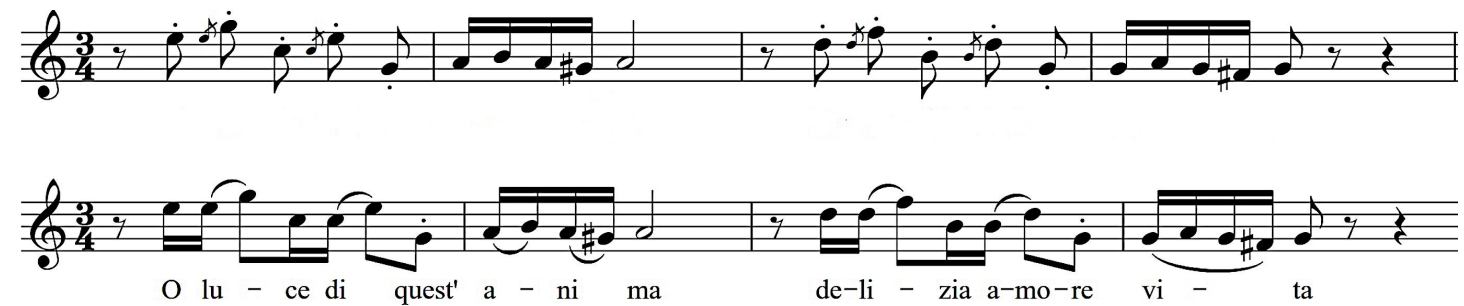

Figure 12. Alternative way of performing ornaments of ' $\mathrm{O}$ luce di quest'anima'(Bars 40-43)

\section{3) Cadenza}

It should be clear that the cadenza phrases in nineteenth-century operas are not only showing off skills, but also related to expressing emotions. Therefore, the cadenza phrases here are also the expression of Linda's longing for love and the joy in her heart. The cadenzas of this aria have not been written out by the composer, so there are many different possible versions of the cadenzas. ${ }^{74}$ I think adding a cadenza to musical phrases is an art, and we need to take care to grasp the scale of these. It will be too complicated if the cadenza is added in a way that means the audience cannot hear the original melody. Through considering a variety of recorded versions, I have chosen to perform the following version of interpretation which adds a leap to the melody (see Figure 13).

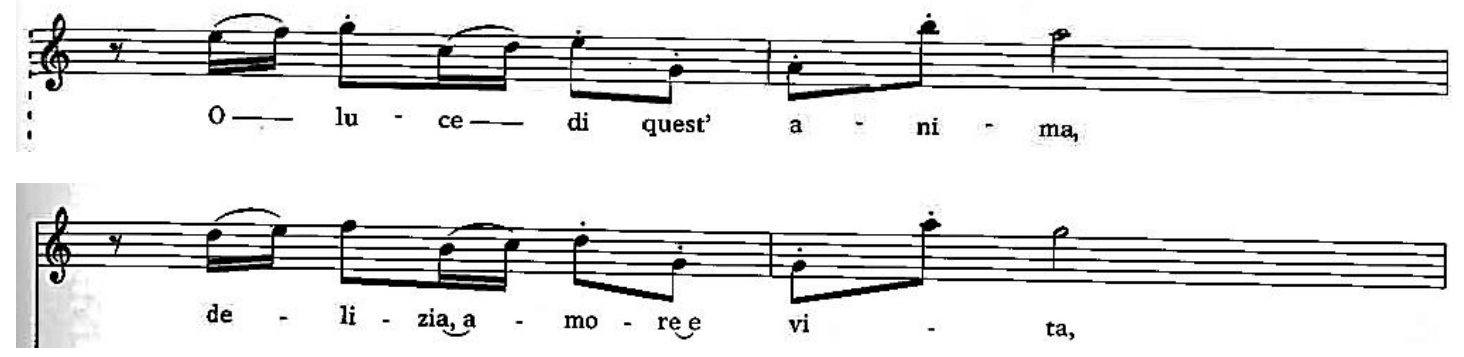

\footnotetext{
74 Joseph P Swain, "Form and function of the classical cadenza," The Journal of Musicology 6, no. 1 (1988): $27-28$.
} 
Figure 13. Fragment of 'O luce di quest'anima' (Bars 74-77)

In the second part of the coda, there are gradual progressively ascending phrases (see Figure 14). This string of notes requires clear singing and good accurate pitching. When I first started singing these four progressive scales, my breath and voice position was always unstable. When I was singing, I could not sing fast, and the rhythm was not correct. Later I realized that this is syncopation, and there are accent marks. Therefore, I tried to make the accent of syncopation while singing. The singer can use this accent as a support, and keep the breath position of their voice unchanged when the scale is on, which will make the breath and sound more stable. As a result, the performer can sing flexibly when singing the scale, and the singer can also maintain her intonation.

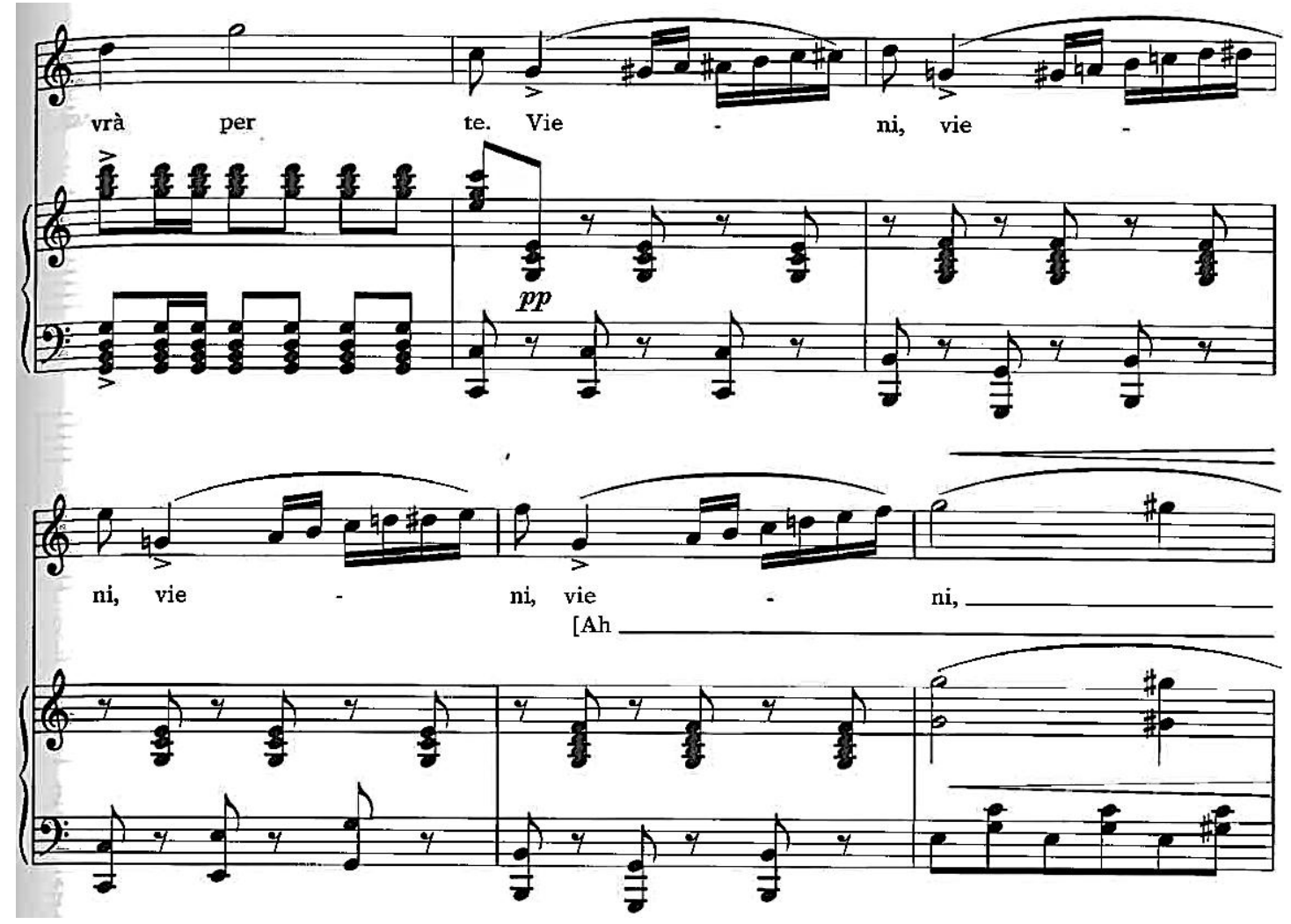

Figure 14. Fragment of 'O luce di quest'anima' (Bars 107-112)

'Ah! tardai troppo... O luce di quest'anima' shows the joy of the heroine Linda immersed in love. I think that the singing of an aria cannot be separated from the 92 
opera itself. Before singing, we should first understand the story of the opera, and know the characteristics of the characters, and the scenes' content when the aria occurs, so that we can sing with the emotions of the characters in the play as I have outlined above. The analysis of the music then lets us know through what musical means the composer intends us to express the emotion in the music. The main motivation of this aria is to vividly express Linda's excitement and joy. While this aria is a coloratura aria, the coloratura here is not just to show the performer's singing technique, but a reflection of Linda's happy and enthusiastic emotions. When dealing with these singing skills, it is important to keep strictly in accordance with the composer's original creation. Performers should follow the requirements on the score, and thorough musical processing as I have discussed above can in fact help solve some of their technical problems.

\section{Summary - the fiery energy of the maiden's passionate love}

Three young women who are passionate about love appear in this chapter. Being full of love these girls are positive and passionate about their feelings. However, these girls have different attitudes towards love. Gretchen repeatedly expresses in the song that she cannot rest - it is impossible for her to calm down because she seems is too eager and obsessed with her lover Faust. Norina is a playful and confident widow. She can use tricks to get a chance to find true love - she is a smart woman who fights for love and sets others hearts alight. Linda is a pure girl who is easily convinced that her lover is poor even though he is not. Linda's mood is not stable when she is in love. At first she will worries that her lover will not love her but soon after, she forgets her troubles and looks forward to a better life with him as her husband.

We can see that Schubert uses his piano accompaniment descriptively in this song, with the piano imitating the rotating spinning wheel within the scene. When used in 
this way, piano accompaniment is able to do the work of the scenic staging employed in opera. In addition, lieder's melody lines may not be as expansive as in opera arias, but the singer needs to change the tone (dark or bright) according to the varieties of the melody colour, thus showing the subtle emotional changes of the character. Arias from this period require some special vocal skills such as those needed for the florid runs and other ornaments in the arias in this chapter. The appearance of coloratura and cadenzas often shows the heroine's laughter and happiness. Since the choice of ornamentation is often left up to the singer, the choice should reflect the singer's own ability but also be chosen on the basis of the emotion the singer wishes to convey. Where similar cadenzas appear more than once within the aria, the intensity, melody, and emotion of the later cadenza can be different, so as to achieve the expression of different levels of character's emotion. 


\section{Discussion: Lieder and Aria Styles and Singing Skills}

\section{Differences in Singing Skills}

Through my study of selected lieder and arias from the first half of the nineteenth century, I have found that bel canto represents a technical means to express both of them in performing musical characters. However, there is a difference between lieder and aria in the use of these singing techniques. Bel canto is not a static singing method, it is a technical means of expressing music. ${ }^{75}$ Therefore, in singing, vocal music should be integrated with notes, emotions, and text, as well as be matched with the corresponding vocal genre (opera or lieder). I will introduce the different requirements and impact of bel canto on lieder and arias in detail below.

\section{1) Difference in Volume}

It can be seen from my previous chapters that piano accompaniment occupies an important position in lieder. This requires the singer to sing at a relatively low volume in order to adapt to the piano accompaniment. Singers should achieve the balance between themselves and the piano accompaniment volume, which is a suitable volume processing method. Moreover, because my aria singing experience is only based on piano accompaniment without orchestra, my research only compares the singing of opera arias with piano accompaniment to lieder, and I will perform the two types of music in the same space and venue in my recital. In general, however, compared with lieder, opera tends to involve more fierce conflicts and more tortuous plots. All these factors imply the need for greater singing volume in arias, because only a large volume can show the personality and emotional changes of the characters in arias who are pushed to the extremes of emotions. Therefore, when singing opera works, performers should try their best to release the ability.

\footnotetext{
75 Robert Toft, Bel canto: A performer's guide, Oxford University Press on Demand, 2013, 3.
} 
2) Difference in Tone

A difference between the singing approach for lieder and arias also exists in the different aspects (emotion or personality) of the character that are shaped by the tone colours. Since the text of lieder mostly come from emotionally lyric poems, special emphasis is placed on the change of tones to express the varieties of emotion. For example, in 'Heidenröslein' (Wild Rose), the anger of wild rose is expressed with a firm and intense tone. In 'Die junge Nonne' (The Young Nun), the dark and soft tone can reflect the nun's despair and struggle. Operas usually use rich characters to form a complete storyline, so in an aria the singer needs a variety of tones to express the diverse aspects of the characters' personalities. For example, the clever Norina in 'Quel guardo il cavaliere' can sing with a light tone. Amina from 'Ah, non credea mirarti', who is kind and innocent, can sing in a lyrical and bright tone.

\section{3) Difference of Voice Range}

The difference between lieder and arias is also reflected in the range of pitches they demand. Looking at the repertoire in my study, it can be seen that the vocal range for the lieder is slightly narrower than for the arias. In Schubert's 'Gretchen am Spinnrade' and Schumann's Frauenliebe und -leben, the voice range is only around ten degrees. Therefore, choosing some lieder suitable for yourself to sing is a better choice for some singers with a narrower range, especially beginners in vocal learning. One reason why the operatic works are more difficult to master is because of their wider voice range. This is perhaps because of the sharp conflicts and complex stories involved in the opera.

\section{Differences in performance}

The most important difference between lieder and operatic arias is not simply the difference arising from the singing skills, but the diagnosis and interpretation of the content of music. That is to say, these two artistic forms have great differences in the 
performance of musical emotions. The emotional expression of lieder singing can be the singer's understanding of the work to convey the emotion with music. There are no specified roles in some lieder. In these types of works, it only describes object purely, and does not stipulate the characters' age, background, personality and other conditions, such as Schubert's 'Heidenröslein' (Wild Rose). Although we can metaphorize the wild rose as a girl, the composer does not create a specific female image. The purpose of this kind of lieder is only to express the feelings of the inner world of the songwriter. In this case, each singer is the most real role, they express only 'self' but not play 'other' roles. However, for opera arias, the singer needs to analyze the roles, and then understand the emotions corresponding to different roles in different angles. The emotional tone of these characters also determines the emotional tone of the entire music. There are many ways for singers to express their feelings, such as voice, facial expressions, body language, stage props and so on. ${ }^{76}$ By these means, the emotions and connotations that the singer wants to express are accepted by the audience.

Text is very important for the expression of emotion in any vocal works. From this we know that the shaping of musical emotion is closely related to literature and drama. In the aesthetic process of music emotion, the dramatic and literary factors represented by text are indispensable. A large number of opera scripts are based on brilliant novels. There may be intense and massive conflicts in their storylines. These contradictions and conflicts are expressed through singing and music, thus forming a dramatic factor of aria. For example, in 'Ah, non credea mirarti... Ah! non giunge' (from La Sonnambula), Amina is misunderstood by her lover in the cavatina part because she walks into the other man's room by mistake and shows sadness. But in the later cabaletta part, her lover sees that she is sleepwalking and finally they get back together. This kind of plot is conflicting. However, in lieder, lots of poems by

\footnotetext{
${ }^{76}$ Mark Ross Clark, Singing, acting, and movement in opera: A guide to singer-getics, Indiana University Press,
} $2009,58$. 
famous poets are often used as lieder's lyrics. In these poems, most of them express the author's praise of sweet love or their response to all aspects of social reality. Among them, it is not very involved in the fierce dramatic conflicts, but lieder rely on the perfect combination of music and poetry.

The stage performance requirements for singers of lieder are also different. Compared with aria performance, lieder requires less physical movement. However, its performance is arguably more difficult than opera, because performers singing lieder do not have a free performance environment, and are not able to utilise performance props. For lieder performance, most of the time when the singer expresses emotions, they can only make use of the voice to express the character, emotions and meanings of the work. In arias, the singer's movements and acting on stage is considered very important. Operas have a well-defined plot, and also specific actions may be indicated or required for some arias. For example, when singing 'Ah, non credea mirarti', because the heroine is in sleepwalking, singers must portray this while singing. When singing 'Quel guardo il cavaliere', the heroine is reading a romance novel, so in a staged production the performer needs to sing while holding the book, and even in a concert performance a singer may choose to make use of this as a prop. In both lieder and arias however, in order to perform with a dynamic and realistic effect, the singer needs to coordinate the singing voice with all aspects of body language and expression. 


\section{Conclusion}

The aim of this study was to investigate the specific vocal skills needed to shape these maiden images, as well as the similarities and differences between characters in opera and lieder who express the varied emotions of love. My intended purpose was to enhance the audience's understanding of such songs and develop my own ideas about how to express emotions through the music in these two different genres.

This exegesis describes the character and emotional changes of these unmarried female characters by analyzing text, piano accompaniment, and compositional features. Based on the features of the characters that have been studied, it then explores the question of how to better shape the characters. Later, the vocal technology about the image, age and emotional change of these unmarried girls is discussed. Among them, when studying and analyzing the difficulties of singing, giving examples of various singing problems, and I have offered suggestions of ways to overcome these difficulties. Finally, through the singing techniques and performance methods summarized above, I have compared the difference between performance aspects of lieder and arias, including suggestions for the approach to shaping the characters of unmarried women.

By analyzing and comparing these selected vocal works, I have found that lieder present relatively few vocal challenges in shaping the image of unmarried women compared to arias. When just singing one lied, there are many times when the voice alone is used to express emotional changes. In particular, some phrases are repeated often in one song, but the meaning of each time may be expected to be different. This requires the singer to be able to deal with the different skills and emotions, effectively distinguishing the emotional experience of different phrases that are often written out exactly the same, so that the audience can achieve emotional resonance. In addition, 
the balance of vocal and piano accompaniment in volume and emotional performance is also a point that needs to be paid attention to when singing lieder. It is worth mentioning that in the song cycle Frauenliebe und -leben (Women's Love and Life), because the cycle is composed of multiple songs, each song is from a different time in the woman's life, and the singer has to change quickly between those scenes, so it is more quickly than they would have to in an opera role. This also requires the singer to combine the different story of each song when singing, and express the character's personality changes through voice.

An aria requires the use of tones to represent different characters and emotions as well. In addition, there are many specific difficulties of vocal technique in the arias I studied which I found ways to resolve through my own practice and research. I have outlined these vocal techniques below:

\section{Dynamic Processing.}

Keep the softest tone of the whole phrase at the highest note. Secondly, the obvious contrast between the forte and piano of two phrases with different emotions, which is formed to a call and response.

\section{Legato Singing}

When performing legato phrases, singers need to pay attention to the pressure of the breath, so it's clear that breath control is needed so that the larynx and other parts of the vocal production process are able to make the volume change.

\section{Cadenza Singing}

The singer should pay attention to the focus of the breath on the diaphragm. At the same time, the singer should pay more attention to the flexibility of the voice, so that the voice can sing lightly and smoothly with the support of the breath.

4. Singing of appoggiatura and acciaccatura 
Pay attention to singing accent. The sound needs to be short and clear, bouncy and flexible.

\section{Trill}

Pay attention to the intensity of the voice. Singers needs to control their breathing evenly to control their voice.

\section{Rapid Scale}

The singer can use an accent in the scale as a support, and keep the breath position unchanged when the scale goes up. This will stabilise the breath and voice.

\section{Staccato and Line}

In some of the arias where it is indicated to sing with staccato to express the character's cheerfulness it should be noted that singing with staccato must not destroy the continuity of the phrase.

\section{Ornaments}

The most important thing is that ornaments are used expressively and not just to show techniques. Performers can adjust the duration and phrasal shaping of ornaments and other notes appropriately to make the ornaments more clear and expressive.

All of my chosen vocal works, lieder and arias, describe experiences of virgins as interpreted by the different composers, and I would like to summarise how characters experiencing similar types of situations are portrayed musically (as in each chapter). In the chapter of First Love, both works are lieder. The composers use piano accompaniment as an emotional carrier to directly express the girls' inner conflicting emotions. The singer enhances the tone of the dialogue between the characters while singing, and can highlight the character of the tenacious (wild rose) or fascination (Frauenliebe) by slightly increasing the volume and sound intensity. Regarding the chapter of Sad Love, lieder's piano accompaniment creates a real feeling in the song. In the aria, the singer follows the changes in the colour of the music to show the helplessness, grievance or questioning of the heroine. In addition, lieder emphasise 
the harmony between human voice and piano. The arias require particular vocal techniques to show the emotional contrast of the characters through florid ornamentation. In the songs and arias selected for the chapter Passionate Love, I found that the piano accompaniment in lieder may do the work of staging as in an opera, yet it also requires the singer to change the tone (dark or bright) according to the varieties of melody colour to show the emotional changes of the character. The coloratura and cadenzas in arias can show the characters' laughter and joyful feelings, and can also express the heroine's sorrowful cry but they can also be performed in different ways to achieve the expression of different levels of the character's emotion.

In terms of performance, lieder's emotional expression of singing can be based on the singer's own understanding of the work and she can use the music to convey the character's emotions. On the contrary, when singing an aria, the singer first needs to put herself in the role and consider the whole of the opera's plot from the point of view of that character. In addition, in lieder, since body movement requirements are less, more emphasis is placed on the stories and emotions expressed solely by the voice. In arias, more exaggerated physical movements are allowed, to embody the communication of the plot.

Moreover, the singer's expression of the age and emotional changes of the girl's image needs to involve changes in the volume and tone used. These are thought of as inseparable from the breath support in bel canto technique and I have found this to be an important aspect of the understanding I have developed through doing this research project. The act of singing starts from the diaphragm (or lower part of the abdominal area) and extends all the way to our throat. According to bel canto teaching, with good breathing support and an open throat position, the singer can sustain the long lines and even resonance required to perform both lieder and Italian opera from the early nineteenth century. 
Most nineteenth century unmarried female characters have only been portrayed in relation to their pursuit of love and infatuation with their lovers. The marriage tradition in these works is obviously different from a modern context. It is clear from the works that the inability to make free choices in terms of marriage like a modern woman was a common experience of women at that time. However, in these selected works, there are some heroines who manage to behave differently from the prevailing female characterisations and expectations. For example, Norina shows off her flirting tricks and then uses those tricks to tease Don Pasquale for her own purposes. The young nun dedicates herself to God so as to gain inner peace. Therefore, we can see the love style of the unmarried women characters in the works I have chosen are very diverse.

I am surprised at the way the female characters are written in the selected songs. There are two points. The first point is that in the songs I chose, the woman's love always has real and fully-developed feelings. Emotional changes of maiden characters often appear in these songs. Composers change the melody line from a point of tension to stretch through the tonality changes (minor to major), thus reflecting the psychological varieties of the female roles from struggling to relief, or from anxiety to fantasy. In this way, composers begin to focus on describing the heroine's exaggerated obsession with love. Some of these female characters also seem to be more reckless in their approach to loving relationships than I expected. At the same time, some of them display self-denial and a lack of confidence in front of their lovers, which may in fact still reflect both their loyalty and passionate love for their lovers.

Another point which I found particularly interesting was that the text content created by the writers of this period was no longer limited to myths or narratives based on the court nobility. Vocal works begin with songs featuring country girls as the protagonist, 
instead of just talking about the love life of noble girls. These textual plots are probably close to the real life of the expanding middle classes who increasingly formed the audience for such works at that time, because some female figures are ordinary girls from the countryside. There are still stories of noble girls, however, this is no longer just a description of love, but in their tragic love, the heroine from an aristocratic family may break through feudal marriages and pursue personal happiness. In fact, in the nineteenth century, many women did actually have a say in who they married, though they still often needed their father or guardian to sanction the marriage. Therefore, although male composers and their librettists may often have exaggerated the punishment enacted upon women who transgressed the societally acceptable limits on love for dramatic effect, there are a large number of female characters who dare to compete with fate in the songs I have studied here. Although such characters prove unable to overcome the patriarchal shackles that bind them, they also demonstrate that women had the ability to influence the creative aesthetics of the composers at the time. Moreover, a skillful female singer can reveal the underlying agency held by in these characters.

Areas for future research around this topic include the study of the female character in nineteenth-century vocal works after 1850 , thus providing a more complete guide for the performance of the female character in works from this period, and further insights into the development of vocal music written for performance by women. In addition, as the increased attention received by women in the later nineteenth century and their improvement in social status and rights may affect the creative contents of male composers writing in later periods, researchers can also use this as a starting point to explore the changes in women's influence on music history from the nineteenth century to the present, and the way women write for women singers, as opposed to the images crafted by the male composers highlighted in this study. The research I have undertaken in this project has inspired me to look more deeply into the 
variety of approaches to the characterisation of female characters in performance and the musical expression of their emotions in all genres and eras of classical vocal music. 


\section{Bibliography}

Abbate, Carolyn. "Opera; or, the Envoicing of Women." Musicology and difference: gender and sexuality in music scholarship (1993): 225-58.

Apel, Andrea M. "German Lieder: Songs for Women." McNair Scholars Research Journal 3, no. 1 (2011): 5.

Barkin, Elaine, and Lydia Hamessley, eds. Audible traces: Gender, identity, and music. Theodore Front Music, 1999.

Bell, A. Craig. The Songs of Schubert. Lowestoft: Alston Books, 1964.

Brown, Maurice John Edwin, and Eric Sams. The New Grove Schubert. WW Norton \& Company, 1983.

Bodley, Lorraine Byrne. Schubert's Goethe Settings Burlington, VT: Ashgate, 2003.

Clark, Mark Ross. Singing, acting, and movement in opera: A guide to singer-getics. Indiana University Press, 2009.

Cowgill, Rachel, and Hilary Poriss, eds. The arts of the prima donna in the long nineteenth century. Oxford University Press, 2012.

Daverio, John, and Eric Sams. "Schumann, Robert." Grove Music Online. Oxford Music Online (2001).

Donizetti, Gaetano. Don Pasquale. O. Ditson, 1888. 
Evergates, Theodore. "Aristocratic Women in the County of Champagne." Aristocratic Women in Medieval France (1995): 74-110.

Fisher, Burton D. Donizetti's Don Pasquale (Opera Journeys Mini Guide Series)., 2006.

Goydke, Katja N., Eckart Altenmüller, Jürn Möller, and Thomas F. Münte. "Changes in emotional tone and instrumental timbre are reflected by the mismatch negativity." Cognitive Brain Research 21, no. 3 (2004): 351-359.

Johnson, Graham, 1992, http://www.hyperion-records.co.uk/tw.asp?w=W2153.

Hallmark, Rufus, ed. German Lieder in the nineteenth century. Routledge, 2009.

Harris, Katlin. "Death, the Trout, and the Maiden: Schubert's Instrumental Interpretation of His Lieder." https://www.methodist.edu/wp-content/uploads/2018/09/mr2017_harris.pdf

Harris, Tom, and David Martin Howard, eds. The voice clinic handbook. Compton Publishing Limited, 2018.

Hart, Victoria. "Equals in love:"Frauenliebe und Leben" reconsidered." PhD diss., University of California, Santa Barbara, 2004.

Holm-Hadulla, Rainer Matthias. Goethe's Path to Creativity: A Psycho-Biography of the Eminent Politician, Scientist and Poet. Routledge, 2018. 
Juslin, Patrik N., and John Sloboda, eds. Handbook of music and emotion: Theory, research, applications. Oxford University Press, 2011.

Kimball, Carol. Song: a guide to art song style and literature. Hal Leonard Corporation, 2006.

Kobbé, Gustav, and George Henry Hubert Lascelles Harewood. Kobbé's complete opera book. Random House of Canada Ltd, 1987.

Kocka, Jürgen. "The middle classes in Europe." The European Way: European Societies in the 19th and 20th Centuries. Oxford. Berghahn (2004): 15-43.

Lamperti, Giovanni Battista. The Technics of Bel Canto (1905). Gregory Blankenbehler, 2009.

Lehmann, Lotte. Eighteen Song Cycles; Studies in Their Interpretation. New York: Praeger Publishers, 1972.

"Linda di Chamounix Opera: Work details," Royal Opera House Collections Online, http://www.rohcollections.org.uk/work.aspx?work=212\&row=23\&letter $=\mathrm{L} \&$.

Lloyd, Rosemary. "The nineteenth century: shaping women." A History of Women's Writing in France (2000): 120-146.

Mann, Michael. "Ruling class strategies and citizenship." Sociology 21, no. 3 (1987): 339-354. 
Matošec, Matjaž. "“Female Voices in Male Bodies": Castrati, Onnagata, and the Performance of Gender through Ambiguous Bodies and Vocal Acts." Master's thesis, 2008.

McCauley, Megan Evangeline. A woman's timeless path of life and love: Voicing and the feminine persona in Robert Schumann's "Frauenliebe und Leben”, Opus 42, and David Eddleman's “Journey”. University of Kentucky, 2010.

McNamara, Jo Ann. Sisters in Arms Catholic Nuns through Two Millennia 1st Harvard University Press paperback ed. Cambridge, Mass: Harvard University Press, 1998.

"Medieval Nuns," Lords and Ladies, http://www.lordsandladies.org/medieval-nuns.htm.

Mellers, Wilfrid. Celestial music?: some masterpieces of European religious music. Boydell \& Brewer, 2002.

Miller, Richard. Singing Schumann: An Interpretive Guide for Performers Oxford: Oxford University Press, 2005.

Miller, Richard. Training soprano voices. Oxford University Press, USA, 2000.

Painter, Sidney. French Chivalry: Chivalric Ideas and Practices in Mediaeval France. Cornell University Press, 1940.

"Premiere - I CAPULETI E I MONTECCHI - Opera by Vincenzo Bellini," Sofia Opera and Ballet, 
https://www.operasofia.bg/en/news-and-events/item/8181-premiere-i-capuleti-e-i -montecchi-opera-by-vincenzo-bellini.

Reece, Tyler Michael-Anthony. "Liebe und Leben: Exploring Gender Roles and Sexuality in Nineteenth-Century Lieder." PhD diss., UC Santa Barbara, 2019.

Richard. "Goethe's Heidenröslein." Figures of Speech. Updated July 25, 2017. http://figures-of-speech.com/2017/06/r\%C3\%B6slein.htm.

Riva, Michele Augusto, Caterina Mazzocchi, Giancarlo Cesana, and Stanley Finger. "'Il Sonnambulo' by Michele Carafa: A Forgotten Romantic Opera with Sleepwalking." European neurology 76, no. 5-6 (2016): 210-215.

Rutherford, Susan. The prima donna and opera, 1815-1930. Cambridge University Press, 2006.

Sadie, Stanley, and J. Tyrrell. "Dictionary of music and musicians." 2001.

Schoep, Arthur, and Daniel Harris. Word-by-word Translations of Songs and Arias, Part II: Italian: a Companion to the Singer's Repertoire. Rowman \& Littlefield, 1972.

Senici, Emanuele. Landscape and Gender in Italian Opera: The Alpine Virgin from Bellini to Puccini. Cambridge University Press, 2005.

Stark, James. Bel canto: a history of vocal pedagogy. University of Toronto Press, 1999. 
Swain, Joseph P. "Form and function of the classical cadenza." The Journal of Musicology 6, no. 1 (1988): 27-59.

Toft, Robert. Bel canto: A performer's guide. Oxford University Press on Demand, 2013.

Youens, Susan. “Song Cycle.” Grove Music Online. Oxford University Press, January $20,2001$. 